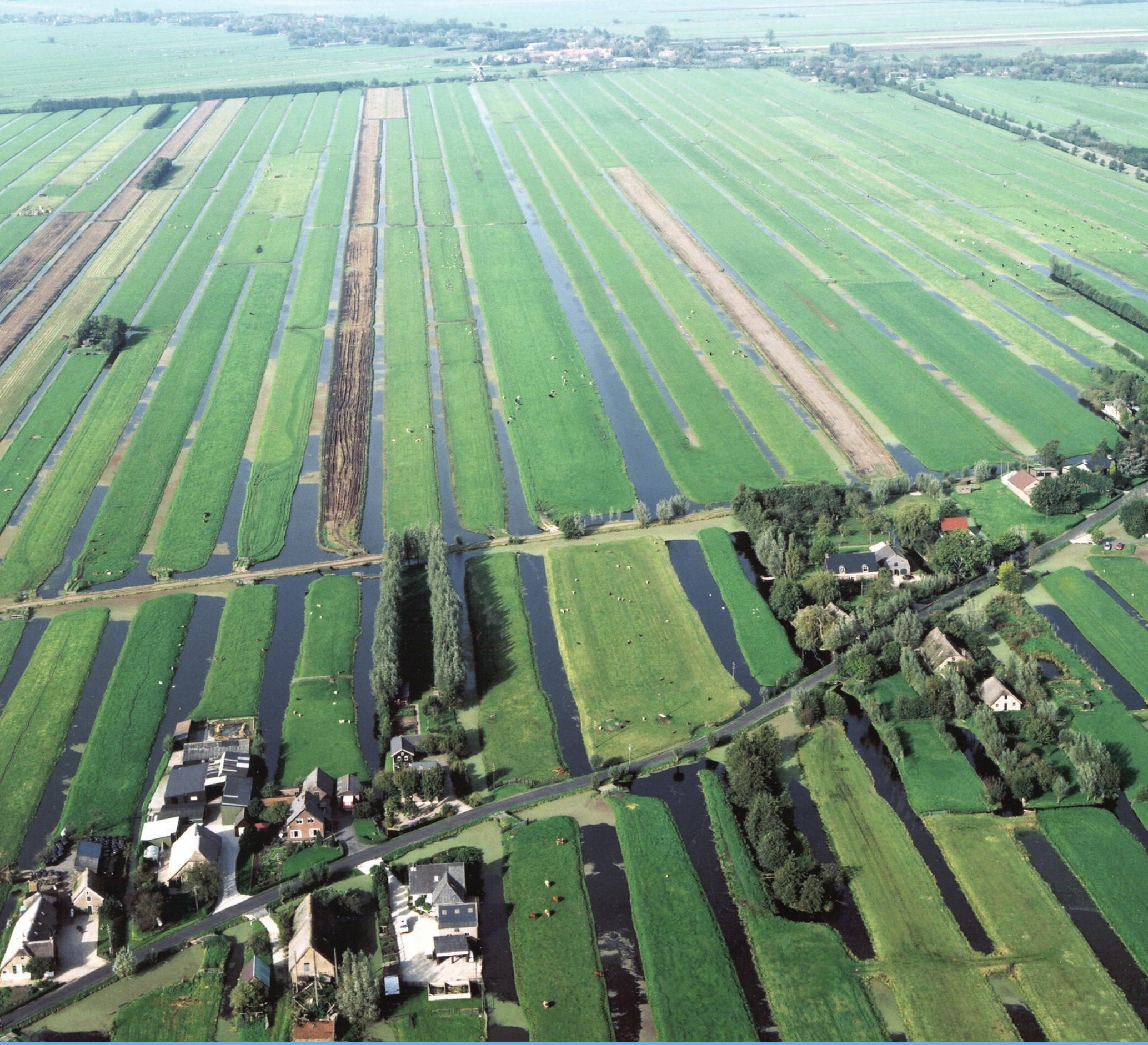

Belasting van waterlichamen in de Krimpenerwaard met stikstof en fosfor 



\section{Belasting van waterlichamen in de Krimpenerwaard met stikstof en fosfor}

P.N.M. Schipper, R.F.A. Hendriks, H.T.L. Massop en E.M.P.M. van Boekel

Dit onderzoek is uitgevoerd door Wageningen University and Research (Alterra) in opdracht van en gefinancierd door het Hoogheemraadschap van Schieland en de Krimpenerwaard.

Wageningen Environmental Research (voorheen Alterra)

Wageningen, augustus 2016

Rapport 2738

ISSN 1566-7197 
Schipper, P.N.M., R.F.A. Hendriks, H.T.L. Massop en E.M.P.M. van Boekel, 2016. Belasting van waterlichamen in de Krimpenerwaard met stikstof en fosfor. Wageningen, Wageningen Environmental Research, Rapport 2738. 76 blz.; 26 fig.; 23 tab.; 15 ref.

Om inzicht te krijgen in de herkomst van nutriënten in de Krimpenerwaard is een modelinstrumentarium gebouwd dat de waterbalans en nutriëntenbalans in beeld brengt voor vier afwateringsgebieden binnen de Krimpenerwaard. Vervolgens is de beïnvloedbaarheid van bronnen afgeleid conform de werkwijze die wordt toegepast door de Nutriëntenwerkgroep Rijn-West. Uit de resultaten blijkt dat er tussen de vier afwateringsgebieden duidelijke verschillen zijn in herkomst van de stikstof- en fosforbelasting van het oppervlaktewater en de beïnvloedbaarheid hiervan. In de Nesse is het grootste gedeelte moeilijk/niet beïnvloedbaar door de relatief hoge bijdrage van de uit- en afspoeling vanuit natuurgronden, voor de Krimpenerwaard is het grootste gedeelte beïnvloedbaar met een direct effect door de aanvoer van nutriënten via inlaatwater.

Met het modelinstrumentarium is verder verkend wat het effect is van een aantal scenario's op de nutriëntenbelasting naar het oppervlaktewater. In het autonome scenario daalt de af- en uitspoeling van stikstof in de periode 2015-2029 t.o.v. de huidige situatie (2014) met ca. 15\%, de fosforbelasting verandert door de sterke buffering van de bodem bijna niet of neemt zelfs wat toe. Door verruiming van het areaal natuur, aanleg van onderwaterdrainage op koopveengronden en lagere bodemoverschotten door kringlooplandbouw, neemt de af- en uitspoeling ten opzichte van de autonome situatie met ca. 10 à $20 \%$ af.

Trefwoorden: Krimpenerwaard, ECHO, waterbalans, nutriëntenbalans, beïnvloedbaarheid bronnen, SWAP, ANIMO

Dit rapport is gratis te downloaden van http://dx.doi.org/10.18174/388421 of op www.wur.nl/environmental-research (ga naar 'Wageningen Environmental Research' in de grijze balk onderaan). Wageningen Environmental Research verstrekt geen gedrukte exemplaren van rapporten.

2016 Wageningen Environmental Research (instituut binnen de rechtspersoon Stichting Wageningen Research), Postbus 47, 6700 AA Wageningen, T 03174807 00, E info.alterra@wur.nl, www.wur.nl/environmental-research. Wageningen Environmental Research is onderdeel van Wageningen University \& Research.

- Overname, verveelvoudiging of openbaarmaking van deze uitgave is toegestaan mits met duidelijke bronvermelding.

- Overname, verveelvoudiging of openbaarmaking is niet toegestaan voor commerciële doeleinden en/of geldelijk gewin.

- Overname, verveelvoudiging of openbaarmaking is niet toegestaan voor die gedeelten van deze uitgave waarvan duidelijk is dat de auteursrechten liggen bij derden en/of zijn voorbehouden.

Wageningen Environmental Research aanvaardt geen aansprakelijkheid voor eventuele schade voortvloeiend uit het gebruik van de resultaten van dit onderzoek of de toepassing van de adviezen.

Wageningen Environmental Research Rapport 2738 | ISSN 1566-7197

Foto omslag: Luchtfoto van de Krimpenerwaard (aangeleverd door het Hoogheemraadschap Schieland en de Krimpenerwaard) 


\section{Inhoud}

$\begin{array}{ll}\text { Samenvatting } & 5\end{array}$

1

Projectdefinitie $\quad 9$

1.1 Aanleiding en projectdoelstelling 9

1.2 Methode 9

$\begin{array}{lll}1.3 & \text { Leeswijzer } & 10\end{array}$

2

$\begin{array}{ll}\text { Gebiedsanalyse } & 11\end{array}$

2.1 Indeling in bemalingseenheden $\quad 11$

2.2 Landgebruik $\quad 12$

$\begin{array}{lll}2.3 & \text { Bodem } & 14\end{array}$

$\begin{array}{lll}2.4 & \text { Meteo } & 15\end{array}$

$\begin{array}{lll}2.5 & \text { Kwel en wegzijging } & 16\end{array}$

$\begin{array}{ll}2.6 & \text { Polderpeilen en drooglegging } \\ 2.7 & 17\end{array}$

$\begin{array}{lll}2.7 & \text { In- en uitlaat } & 18\end{array}$

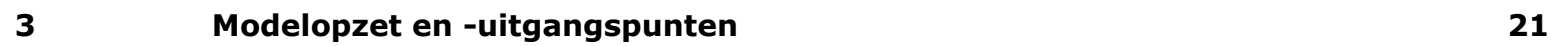

$\begin{array}{lll}3.1 & \text { Inleiding } & 21\end{array}$

$\begin{array}{lll}3.2 & \text { Opzetten rekenplots uit- en afspoeling } & 21\end{array}$

$\begin{array}{lll}3.3 & \text { Resulterende plotindeling } & 24\end{array}$

$\begin{array}{lll}3.4 & \text { Bemesting en gewasopame } & 25\end{array}$

$\begin{array}{lll}3.5 & \text { Inlaat en uitlaat } & 27\end{array}$

$\begin{array}{lll}3.6 & \text { Overige bronnen } & 28\end{array}$

$\begin{array}{lll}3.7 & \text { Retentie } & 29\end{array}$

3.8 Modellering en toetsing water- en stoffenbalans 30

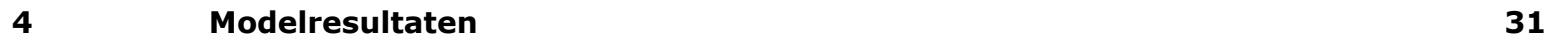

$\begin{array}{lll}4.1 & \text { Waterbalans } & 31\end{array}$

4.2 Uit- en afspoeling $\quad 32$

$\begin{array}{lll}4.3 & \text { Overige emissies } & 33\end{array}$

4.4 Nutriëntenbalans 33

$\begin{array}{lll}4.5 & \text { Herkomst analyse uit- en afspoeling } & 37\end{array}$

$5 \quad$ Scenario's $r 4$

$\begin{array}{lll}5.1 & \text { Inleiding } & 41\end{array}$

$\begin{array}{lll}5.2 & \text { Uitgangspunten scenario's } & 41\end{array}$

5.3 Berekende effecten autonome situatie $\quad 44$

$\begin{array}{lll}5.4 & \text { Berekende effecten scenario's } & 46\end{array}$

$6 \quad$ Discussie modelberekeningen af- en uitspoeling $\quad 50$

$\begin{array}{lll}6.1 & \text { Modelberekeningen waterbalans } & 50\end{array}$

6.2 Modelberekeningen nutriëntenbronnen $\quad 51$

$\begin{array}{llr}7 & \text { Conclusies en aanbevelingen } & 54\end{array}$

$\begin{array}{lll}7.1 & \text { Conclusies } & 54\end{array}$

$\begin{array}{lll}7.2 & \text { Aanbevelingen } & 55\end{array}$

$\begin{array}{ll}\text { Literatuur } & 56\end{array}$ 
Bijlage 1 Overzicht rekenplots 57

Bijlage 2 Methodiek retentie 62

Bijlage 3 Waterbalansen

65

Bijlage 4 Uit- en afspoeling nutriënten

67

Bijlage 5 Nutriëntenbalansen

71 


\section{Samenvatting}

Hoogheemraadschap Schieland en de Krimpenerwaard (HHSK) staat voor de taak maatregelen te bedenken en uit te voeren om in het komende decennium te gaan voldoen aan de doelstellingen van de Kaderrichtlijn Water. Conform de afspraken binnen Rijn-West wil HHSK transparant inzicht hebben in de herkomst van de nutriëntenbelasting in de Krimpenerwaard om daarmee goed onderscheid te kunnen maken tussen de bijdrage vanuit de veenbodems, de bijdrage via inlaatwater, de invloed van bemesting en overige nutriëntenbronnen.

\section{Methode voor analyseren van de nutriëntenbronnen}

De Krimpenerwaard is in deze studie ingedeeld in vier waterbalanseenheden: De Nesse, Johan Veurink, Krimpenerwaard en Verdoold (Stolwijkersluis). Voor het ontrafelen van de nutriëntenbronnen van het oppervlaktewater en het daaruit kwantificeren van de achtergrondbelasting zijn water- en stofbalansen (stikstof en fosfor) opgesteld. Deze balansen zijn opgezet op het niveau van de vier onderscheiden deelgebieden.

Voor het opstellen van water- en stofbalansen voor de vier deelgebieden in de Krimpenerwaard is de methode ECHO toegepast. Deze methode combineert model- en data-analysetechnieken die zijn ontwikkeld voor de ex ante-evaluatie van de KRW, Evaluatie van de Meststoffenwet en monitoring- en modelstudies op regionaal niveau. De nadruk in onderhavige studie ligt op het modelleren van de uiten afspoeling van water en nutriënten met SWAP-ANIMO. Deze modellen vormen de basis (rekenplots) van het landelijk modelinstrumentarium STONE, dat word ingezet voor de evaluatie van de Meststoffenwet.

De in deze studie toegepaste methode ECHO maakt gebruik van SWAP-ANIMO-rekenplots die in de studie Monitoring Stroomgebieden specifiek zijn opgezet om de uit- en afspoeling in de Krimpenerwaard te simuleren. Omdat in Monitoring Stroomgebieden voor de Krimpenerwaard een beperkt onderscheid gemaakt is in het ruimtelijk voorkomen van bepalende kenmerken voor de uit- en afspoeling van nutriënten als bodemsoort, landgebruik en hydrologische kenmerken (kwel/wegzijging), zijn in onderhavige studie meer voorkomende combinaties van bepalende kenmerken doorgerekend. Bovendien wordt bij de modellering rekening gehouden met nieuwe plannen voor de omzetting van landbouw naar natuur.

\section{Modelresultaten waterbalans}

De afstroming en drainage/infiltratie naar het oppervlaktewater is berekend met het model SWAP, voor het oppervlaktewatersysteem zijn de neerslag en verdamping (open water) berekend op basis van KNMI-gegevens en de kwel/wegzijging naar het watervoerende pakket op basis van gegevens van het model MORIA en DINO-peilbuizen. De optelsom van de verschillende balanstermen is het netto debiet, hetgeen gelijkgesteld is aan de uitlaat minus de inlaat. De uit metingen afgeleide uitgaande debieten, aangeleverd door HHSK, zijn benut om de modellering van de afstroming en drainage/infiltratie naar het oppervlaktewater met SWAP te kalibreren. Als uitgangspunt voor de kalibratie is aangehouden dat de langjarig gemiddelde netto-uitlaat (uitlaat minus inlaat) zoals het model berekent, overeenkomt met de uit metingen afgeleide netto-uitlaat.

Op basis van de correlatie tussen de gemodelleerde netto-debieten en de uit metingen afgeleide netto-debieten, wordt geconcludeerd dat de berekende waterbalans voor de vier deelgebieden goed overeenkomt met de debieten van de in- en uitlaat zoals die door het waterschap zijn afgeleid op basis van de meetgegevens. Ook blijkt dat de modelberekeningen qua seizoenpatroon (zomer-winter) goed aansluiten bij de debietgegevens van HHSK. Uit de waterbalansen blijkt dat in de deelgebieden Krimpenerwaard en Nesse relatief veel oppervlaktewater wegzijgt naar het diepe grondwater en ook relatief veel oppervlaktewater infiltreert in het veenpakket. Het netto-debiet voor deze twee gebieden is dan ook negatief (de inlaat is groter dan de uitlaat). 


\section{Modelresultaten nutriëntenbalans}

De nutriëntenbalans voor de vier deelgebieden is opgesteld voor de periode 2000-2014. De uit- en afspoeling van stikstof- en fosfor naar het oppervlaktewater vanuit landbouw- en natuurgronden is berekend met het model ANIMO. De aanvoer van nutriënten via inlaatwater is afgeleid op basis van de inlaatdebieten en nutriëntenconcentraties in het inlaatwater, de overige emissies (o.a. erafspoeling, meemesten sloten, rwzi's, atmosferische depositie open water, industriële lozingen, riooloverstorten) zijn afkomstig van de EmissieRegistratie.

De uit- en afspoeling vanuit landbouw- en natuurgronden, inlaatwater en atmosferische depositie (alleen stikstof) zijn de belangrijkste posten in de stikstof- en fosforbalans. Voor de deelgebieden Verdoold en Veurink ligt de bijdrage van de uit- en afspoeling vanuit landbouw- en natuurgronden tussen $61 \%$ en $67 \%$ voor stikstof en tussen $65 \%$ en $77 \%$ voor fosfor. In de deelgebieden Nesse en Krimpenerwaard is het aandeel beduidend lager, omdat er veel wegzijging plaatsvindt en inlaatwater een relatief groot aandeel van de belasting vormt (31-57\% voor stikstof en $47-100 \%$ voor fosfor).

De uit- en afspoeling vanuit landbouwgronden naar het oppervlaktewater varieert sterk over het jaar. De uit- en afspoeling van nutriënten vindt voornamelijk plaats vanaf oktober tot en met maart, in de navolgende maanden (het groeiseizoen) is de af- en uitspoeling veel lager en dan vooral van april tot juli. In die maanden infiltreert ook een significant deel van de in het oppervlaktewater aanwezige stikstof en fosfor in het bodemprofiel. Dit is ook te verwachten, omdat dan de oppervlaktewaterpeilen relatief hoog zijn ten opzichte van de grondwaterstanden.

De plausibiliteit van de nutriëntenbalans is in beeld gebracht door de netto uitgaande stikstof- en fosforbalans naar het oppervlaktewater (Totaal IN minus retentie) te vergelijkingen met de uit metingen en debietgegevens van HHSK afgeleide uitgaande stikstof- en fosforvrachten. Rekening houdend met onzekerheden in zowel de modelberekeningen als de data van HHSK komt de berekende en uit metingen afgeleide netto nutriëntenbelasting voor de vier deelgebieden vrij goed overeen. Alleen voor deelgebied Veurink is de fosforbelasting duidelijk lager dan uit de metingen is afgeleid en voor de Nesse lijkt de stikstofbelasting iets te worden overschat. De resultaten van de berekende water- en nutriëntenbalansen bieden vertrouwen in de analyse van de herkomst en de doorgerekende scenario's.

\section{Herkomst en beïnvloedbaarheid nutriëntenbelasting}

In de nutriëntenbalans is de uit- en afspoeling vanuit landbouwgronden als één term meegenomen. Om inzicht te krijgen in de herkomst en beïnvloedbaarheid van bronnen is het noodzakelijk om, conform de werkwijze die wordt gehanteerd door de Nutriëntenwerkgroep Rijn-West, de bronnen achter de uit- en afspoeling vanuit landbouwgronden in beeld te brengen. Het gaat dan om de bronnen atmosferische depositie, bemesting (actueel en historisch), nalevering vanuit de bodem, kwel en uitspoeling van eerder geïnfiltreerd oppervlaktewater. Voor de onderverdeling van deze bronnen is gebruikgemaakt van de resultaten van de studie Monitoring Stroomgebieden.

Uit de resultaten van Monitoring Stroomgebieden blijkt dat de bemesting en (na)levering vanuit de veenbodem de grootste bronnen zijn van de uit- en afspoeling van stikstof (beide $48 \%$ ). Van de overige bronnen speelt alleen de atmosferische depositie nog een kleine rol (ca. 4\%). Voor fosfor is de bijdrage van de bemesting met bijna $60 \%$ anderhalf keer zo groot als die van de bodem (40\%). Naast de bemesting en (na)levering vanuit de veenbodem heeft alleen de infiltratie van oppervlaktewater nog een zeer geringe bijdrage aan de belasting van datzelfde oppervlaktewater. Het kan hierbij deels om dezelfde fosfor gaan die eerder is uitgespoeld.

Op basis van de herkomstanalyse is vervolgens onderscheid gemaakt tussen bronnen die beïnvloedbaar zijn en direct effect sorteren, bronnen die ook beïnvloedbaar zijn, maar waar effecten pas op korte tot langere termijn zichtbaar worden, en bronnen die niet of nauwelijks in het gebied (regionaal) beïnvloedbaar zijn. 
De herkomst van de belasting is onderverdeeld in drie klassen: 1. Beïnvloedbaar, direct effect, 2. Beïnvloedbaar, korte en lange termijn en 3. Niet/moeilijk beïnvloedbaar. Uit de resultaten blijkt dat er duidelijke verschillen zijn tussen de vier deelgebieden. Zo is voor deelgebied Nesse het grootste gedeelte $(52 \%)$ van de stikstofbelasting niet/moeilijk beïnvloedbaar door de relatief grote bijdrage van atmosferische depositie en uit- en afspoeling vanuit natuurgronden. Voor de deelgebieden Veurink en de Verdoold is het grootste gedeelte van de nutriëntenbelasting beïnvloedbaar met een effect op de korte en lange termijn (50-67\%). In de Krimpenwaard is, als gevolg van de relatief grote bijdrage van inlaatwater aan de nutriëntenbelasting, het grootste gedeelte beïnvloedbaar met een direct effect (61\% voor $\mathrm{N}$ en $58 \%$ voor $\mathrm{P}$ ).

\section{Scenario's}

In deze studie zijn met het opgezette modelinstrumentarium berekeningen uitgevoerd om de effecten te verkennen van een aantal scenario's: 1 . Autonome situatie, 2. Verlaging bodemoverschotten in de melkveehouderij, 3. Uitbreiding van het areaal natuur en 4. Onderwaterdrainage. Het effect van de maatregelen op de nutriëntenbelasting is in beeld gebracht door de huidige situatie (eind december 2014) te vergelijken met de gemiddelde uit- en afspoeling van nutriënten in de periode 2015-2029.

In de autonome situatie daalt de af- en uitspoeling van stikstof zo'n $15 \%$, terwijl fosfor of weinig verandert door de sterke buffering of zelfs wat toeneemt. Dat laatste is een gevolg van de toenemende oplading door bemesting, ook in weidevogelnatuur. De afname van stikstof komt door het langzaam uitputten van de met bemesting verrijkte bodem dat al is ingezet in de berekening van de huidige situatie. De bemesting loopt vanaf 2000 terug en daardoor wordt de bodem langzaam uitgeput door het gewas. Bij fosfor is de tijd daarvoor te kort door de sterke buffering (nalevering vanuit de bodem).

Door verruiming van het areaal natuur, aanleg van onderwaterdrainage op koopveengronden en lagere bodemoverschotten door kringlooplandbouw neemt de af- en uitspoeling verder af. Deze afname is ten opzichte van de autonome situatie met de voor deze scenario's gehanteerde uitgangspunten niet heel groot (ca. 10 a 20\% verdere afname). Deze afname levert verder ook een verbetering van de kwaliteit van het water dat van het ene naar het andere deelgebied wordt doorgevoerd. 


\section{$1 \quad$ Projectdefinitie}

\subsection{Aanleiding en projectdoelstelling}

Hoogheemraadschap Schieland en de Krimpenerwaard (HHSK) staat voor de taak maatregelen te bedenken en uit te voeren om in het komende decennium te gaan voldoen aan de doelstellingen van de Kaderrichtlijn Water. Conform de afspraken binnen Rijn-West wil HHSK transparant inzicht hebben in de herkomst van de nutriëntenbelasting in de Krimpenerwaard om daarmee goed onderscheid te kunnen maken tussen de bijdrage vanuit de veenbodems, de bijdrage via inlaatwater, invloed van bemesting en overige nutriëntenbronnen. Met dit inzicht kan HHSK rekening houden met de achtergrondbelasting voor het eventueel bijstellen van KRW-doelen en kan beter geschat worden welke maatregelen effectief zijn om de nutriëntenbelasting terug te dringen.

In de studie Monitoring Stroomgebieden (Van Gerven et al., 2011) is geconcludeerd dat de nutriëntenbelasting vanuit de agrarisch gebruikte veenweidenbodem een groot aandeel heeft in de totale nutriëntenbelasting van het oppervlaktewater. Hoewel ook het aandeel van de verschillende bronnen is bestudeerd en gemodelleerd, is in die studie slechts een beperkt onderscheid gemaakt in het ruimtelijke voorkomen van bepalende kenmerken voor de uit- en afspoeling van nutriënten als bodemsoort, landgebruik en hydrologische omstandigheden (vooral wegzijging en kwel). Hieruit ontstaat het beeld dat de ruimtelijke variatie van de diffuse belasting vanuit de landbodem in de Krimpenerwaard gering is. Voor een realistischer beeld is het van belang meer voorkomende combinaties van de bepalende kenmerken door te rekenen. Ook dient bij de opzet van de modellering rekening te worden gehouden met de nieuwe plannen voor omzetting van landbouwareaal naar natuur.

Het primaire doel van het project is om kwantitatief vast te stellen wat de bijdrage is van de verschillende stikstof- en fosforbronnen aan de totale belasting van het oppervlaktewater in de te onderscheiden deelgebieden in de Krimpenerwaard. De nadruk ligt op het ontrafelen van de totale nutriëntenbelasting, zodat onderscheid gemaakt kan worden in de belasting die afkomstig is van beïnvloedbare bronnen met een direct effect (inlaat) en een effect op de lange of korte termijn (bemesting en veenbodems) en het aandeel van moeilijk of niet beïnvloedbare bronnen, zoals atmosferische stikstofdepositie. Nevendoel is om globaal inzicht te bieden in het effect van efficiënter mineralenmanagement in de landbouw, ervan uitgaande dat het grootste deel van de agrariërs $(80 \%)$ maatregelen neemt die leiden tot een lager $\mathrm{N}$ - en $\mathrm{P}$-overschot en problemen op het erf zijn afgenomen.

\section{$1.2 \quad$ Methode}

De methode is erop gericht om de nutriëntenbronnen zodanig te ontrafelen, dat onderscheid gemaakt kan worden tussen de nutriëntenbelasting door punt- en diffuse bronnen. Een belangrijk facet hierbij is om de bronnen achter de uit- en afspoeling te ontrafelen, zodanig dat onderscheid gemaakt kan worden tussen de uit- en afspoeling die veroorzaakt wordt door historische en actuele mestgiften, atmosferische depositie en het deel dat veroorzaakt wordt door versnelde mineralisatie en oxidatie van de veenbodems als gevolg van uitloging en ontwatering. Daarom ligt de nadruk op het modelleren van de uit- en afspoeling van water en nutriënten met SWAP-ANIMO. Deze modellen vormen ook de basis (rekenplots) van het landelijke modelinstrumentarium STONE, dat wordt ingezet voor de evaluatie van het mestbeleid. De in deze studie toegepaste methode ECHO maakt gebruik van SWAPANIMO-rekenplots die specifiek zijn opgezet om de uit- en afspoeling in de Krimpenerwaard te simuleren. Met ECHO wordt op regionaal niveau de uit- en afspoeling gekwantificeerd en worden door ook de andere punt- en diffuse nutriënten bronnen te kwantificeren - in nauwe samenwerking met het waterschap water- en nutriëntenbalansen opgesteld. 
Daarmee wordt de totaal berekende belasting gevalideerd en de bronnen onderverdeeld naar de mate waarin deze kunnen worden beïnvloed.

Voor de onderhavige studie zijn de volgende stappen uitgevoerd:

1. Gebiedsanalyse: verzamelen data en actuele studies, gebiedsindeling, analyse van de gebiedskenmerken en schematisering rekenplots SWAP-ANIMO;

2. Waterbalans: berekening inlaat en uitstroom, opbouw rekenplots SWAP-ANIMO;

3. Bronnenanalyse: modellering uit- en afspoeling met SWAP-ANIMO, kwantificering overige punt- en diffuse nutriëntenbronnen, opstellen nutriëntenbalans per deelgebied en modelanalyse ter onderscheid van natuurlijke en antropogene bronnen;

4. Opzetten en berekening van een modelscenario waarbij een significant areaal landbouw wordt omgezet naar natuur en een modelscenario waarbij, uitgaande van inzet op kringlooplandbouw, het bodemoverschot van de melkveehouderijen significant afneemt.

Deze werkwijze is in grote lijnen hetzelfde als de methode $\mathrm{ECHO}$ die is toegepast om de diffuse belasting van water vanuit landbouw- en natuurgronden te kwantificeren en de bronnen verder te ontrafelen met onderscheid in natuurlijk en antropogene bronnen ${ }^{1}$ (zie kader).

ECHO maakt resultaten van het landelijke STONE-model toepasbaar voor regio's. De methode combineert model- en data-analysetechnieken die zijn ontwikkeld voor de Ex Ante-evaluatie van de KRW, de evaluatie van de Meststoffenwet en monitoring- en modelstudies op regionaal niveau. ECHO biedt transparant inzicht in de stoffenbalans, de betrouwbaarheid van de berekende uit- en afspoeling, ontrafelt de herkomst en stuurbaarheid van de nutriëntenbronnen, verbetert de landelijke geschematiseerde rekenplots van STONE met regionale informatie, berekent de achtergrondbelasting en kan ook ingezet worden om effecten van maatregelen te kwantificeren. ECHO levert voor waterlichamen of afvoergebieden een water- en stoffenbalans met inzicht in de:

$>\quad$ in- en uitgaande nutriëntenvrachten op basis van metingen (debieten en concentraties)

$>$ uit- en afspoeling vanuit landbouw- en natuurbodems (regionale optimalisatie STONE-plots)

$>$ bronnen achter de uit- en afspoeling (aandeel bemesting, kwel, depositie)

$>$ overige punt- en diffuse bronnen uit de Emissieregistratie, aangescherpt met regionale gegevens

$>$ retentie van nutriënten in het oppervlaktewater

$>$ mismatch tussen berekende en uit metingen afgeleide $\mathrm{N}$ - en $\mathrm{P}$-vrachten

$>$ onzekerheden in de uit metingen afgeleide vrachten en in de berekende vrachten

\subsection{Leeswijzer}

De gebiedsbeschrijving is opgenomen in hoofdstuk 2. De schematisatie in rekenplots en overige uitgangspunten voor de modellering van de huidige situatie worden behandeld in hoofdstuk 3 . De resultaten voor de huidige situatie worden in hoofdstuk 4 gepresenteerd. De scenarioberekeningen zijn opgenomen in hoofdstuk 5. In hoofdstuk 6 worden de rekenresultaten bediscussieerd. De conclusies en aanbevelingen zijn geformuleerd in hoofdstuk 7.

Details over de rekenplots, berekening van de retentie en de berekeningsresultaten zijn opgenomen in de bijlagen.

\footnotetext{
1 Alterra 2011, ECHO, een methodiek ter ondersteuning van waterbeleid, methodiekbeschrijving en toepassing Drentsche Aa, Alterra 2013, Herkomst nutriëntenbelasting afvoergebieden HDSR, pilotstudie ECHO, Alterra 2014, Achtergrondconcentraties in het oppervlaktewater van HHNK, Hoofdrapport: analyse achtergrondconcentraties voor stikstof en fosfor op basis van water- en nutriëntenbalansen voor het beheergebied van HHNK. Alterra \& Arcadis 2014, Achtergrondbelasting nutriënten Rijnland.
} 


\section{Gebiedsanalyse}

\subsection{Indeling in bemalingseenheden}

De Krimpenerwaard is onderdeel van het Hoogheemraadschap Schieland en de Krimpenerwaard (Figuur 2.1). Binnen de Krimpenerwaard worden de volgende vier bemalingseenheden (waterbalans eenheden) onderscheiden:

- De Nesse

- Johan Veurink

- Krimpenerwaard

- Verdoold (Stolwijkersluis)

5.219 ha

In dit rapport worden voor de vier bemalingseenheden de volgende namen verder aangehouden: Nesse, Veurink, Krimpenerwaard en Verdoold.

De Krimpenerwaard wordt in het zuiden begrensd door de Lek en Nieuwe Maas, in het noordwesten door de Hollandse IJssel en in het noordoosten door de Vlist.

In het zuidwesten grenzen de Stormpolder ( $88 \mathrm{ha}$ ) en De Zaag aan de Krimpenerwaard. Deze polders vallen buiten het studiegebied.

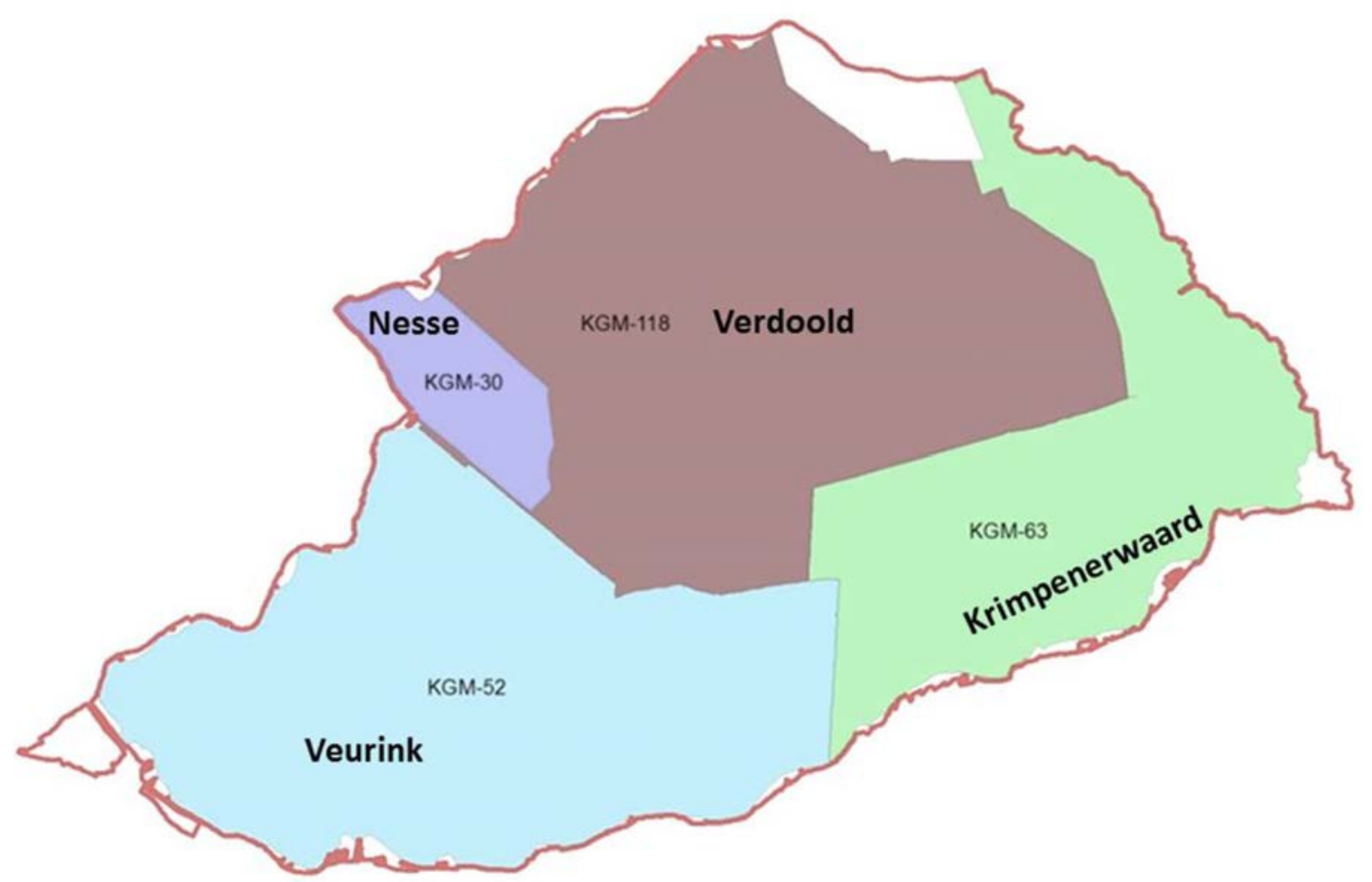

Figuur 2.1 Waterbalansgebieden

Sommige delen van de Krimpenerwaard maken geen deel uit van de vier onderscheiden waterbalansgebieden; dit zijn de witte gebieden, zoals polder Beneden Haastrecht in het noordoosten en het oude centrum van Schoonhoven (rechtsonder). 


\subsection{Landgebruik}

Het landgebruik is afgeleid van LGN7 (Figuur 2.2). In Tabel 2.1 zijn de arealen verdeeld over de waterbalansgebieden weergegeven en daarbij geclusterd naar landbouw, water, stedelijk en natuur.

\section{Tabel 2.1}

Landgebruik volgens LGN7. Het areaal open water is in werkelijkheid groter, volgens HHSK is het areaal open water $13 \%$ in de Nesse, $12,5 \%$ in Veurink, $17 \%$ in Verdoold en $14 \%$ in Krimpenerwaard. In de modelberekeningen zijn de arealen landbouw en natuur hierop gecorrigeerd (iets naar beneden bijgesteld)

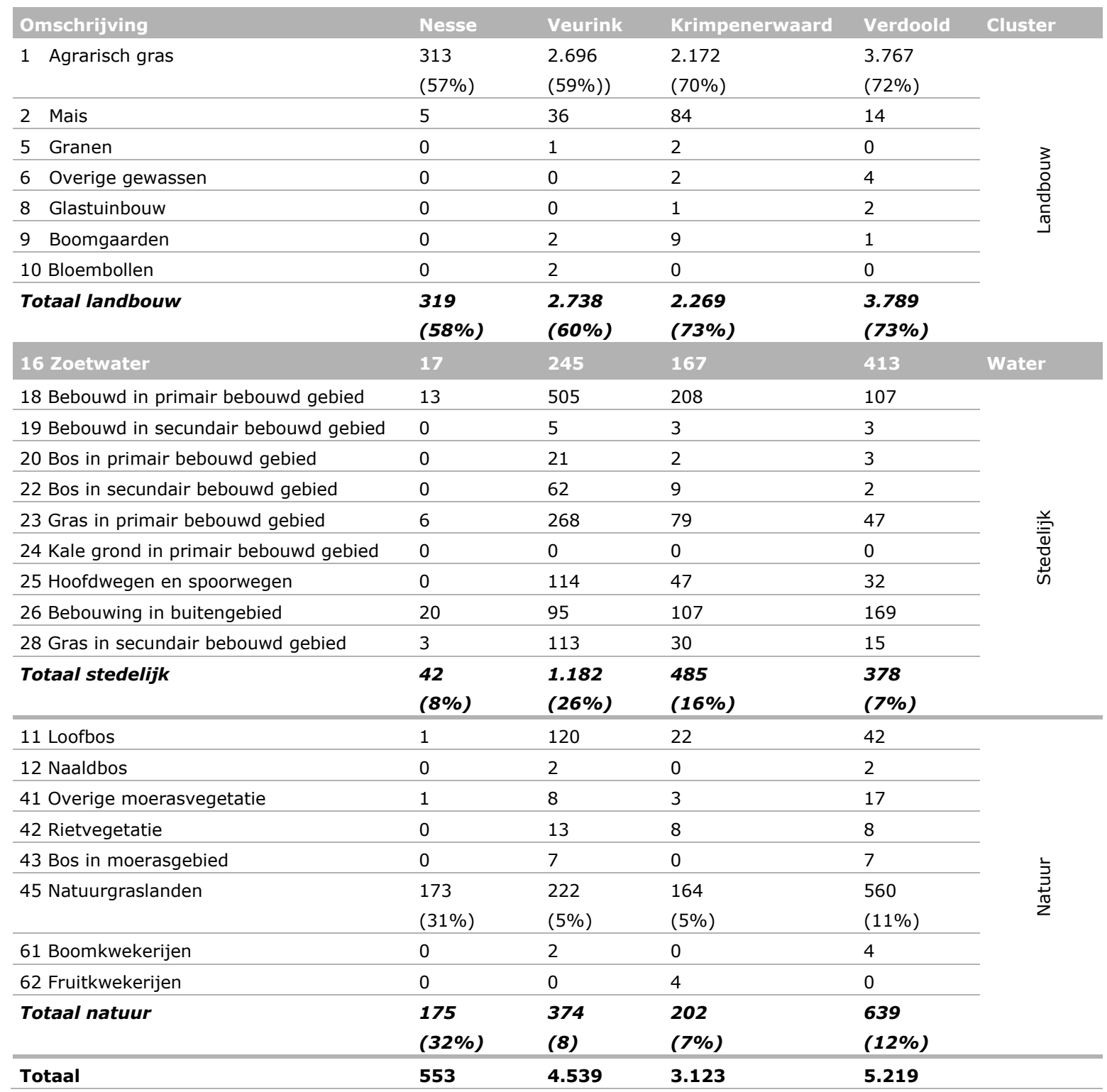

De belangrijkste landgebruiksvormen zijn agrarisch grasland (landbouw/melkveehouders) en natuur grasland, daarom is in Tabel 2.1 tevens aangegeven welk aandeel grasland en natuurgrasland innemen. Het areaal water kan niet goed uit LGN worden afgeleid. Door HHSK zijn de volgende arealen voor het open water per deelgebied aangegeven:
- Nesse
$13,0 \%$
- Veurink
$12,5 \%$
- Krimpenerwaard
$14,0 \%$
- Verdoold
$17,0 \%$ 


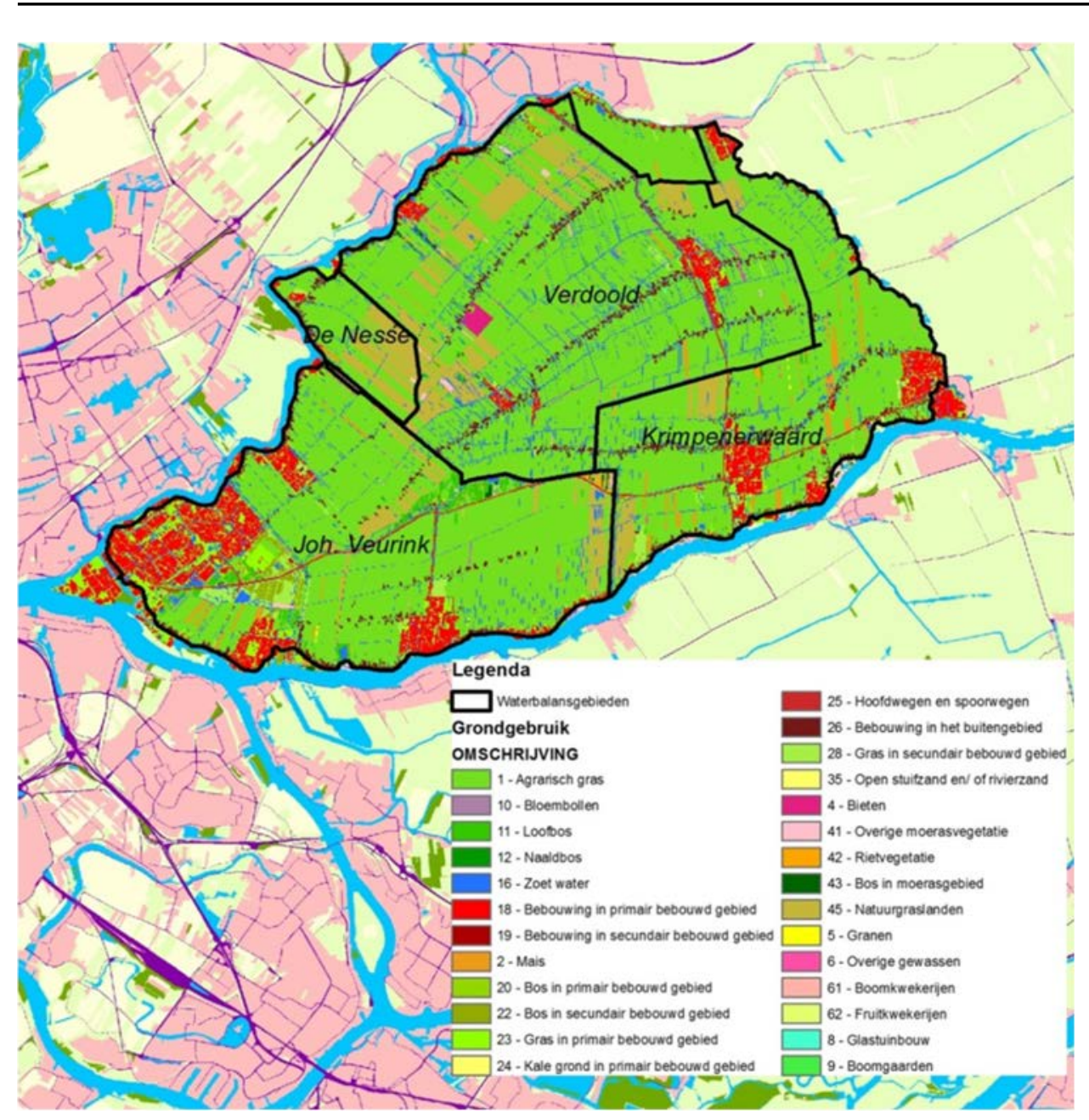

Figuur 2.2 Landgebruik (LGN7) 


\subsection{Bodem}

Er komen meerdere bodemtypen voor binnen de Krimpenerwaard, echter drie bodems vertegenwoordigen samen verreweg het grootste deel van het areaal, namelijk $98 \%$ van de Krimpenerwaard, wanneer geen rekening wordt gehouden met stedelijk gebied en water (Figuur 2.3). De arealen van de verschillende bodemtypen zijn per deelgebied weergegeven in Tabel 2.2.

\section{Tabel 2.2}

Voorkomende bodemtypen en arealen per deelgebied in ha

\begin{tabular}{|c|c|c|c|c|}
\hline Omschrijving & Nesse & Veurink & Krimpenerwaard & Verdoold \\
\hline Veraarde bovengrond op diep veen & 241 & 1.589 & 864 & 4.542 \\
\hline Kleidek op veen & 100 & 1.243 & 1.247 & 342 \\
\hline Klei op veen & 180 & 779 & 694 & 207 \\
\hline Klei op fijn zand & 0 & 76 & 31 & 0 \\
\hline Stedelijk gebied & 30 & 794 & 245 & 118 \\
\hline Totaal & 551 & 4.532 & 3.119 & 5.210 \\
\hline
\end{tabular}

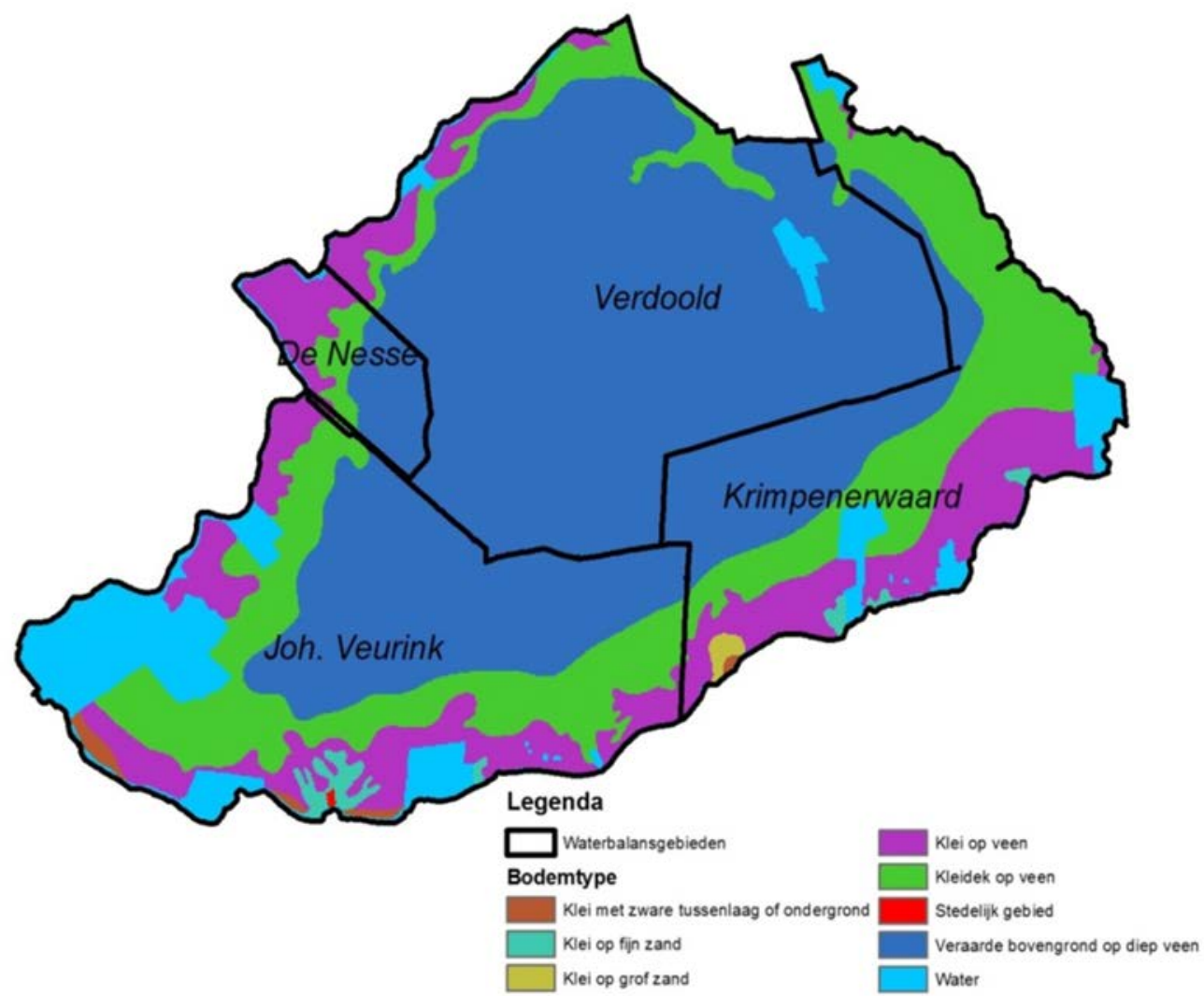

Figuur 2.3 Ruimtelijke spreiding bodemtypen (PAWN) Krimpenerwaard 


\subsection{Meteo}

Rondom de Krimpenerwaard liggen meerdere KNMI-neerslagstations. Als een Thiessennet wordt gemaakt op basis van de KNMI-stations, dan wordt de Krimpenerwaard opgedeeld naar vier KNMIstations, nl. 443 Gouda, 434 Groot Ammers, 451 IJsselmonde en 465 Oud-Alblas (Figuur 2.4).

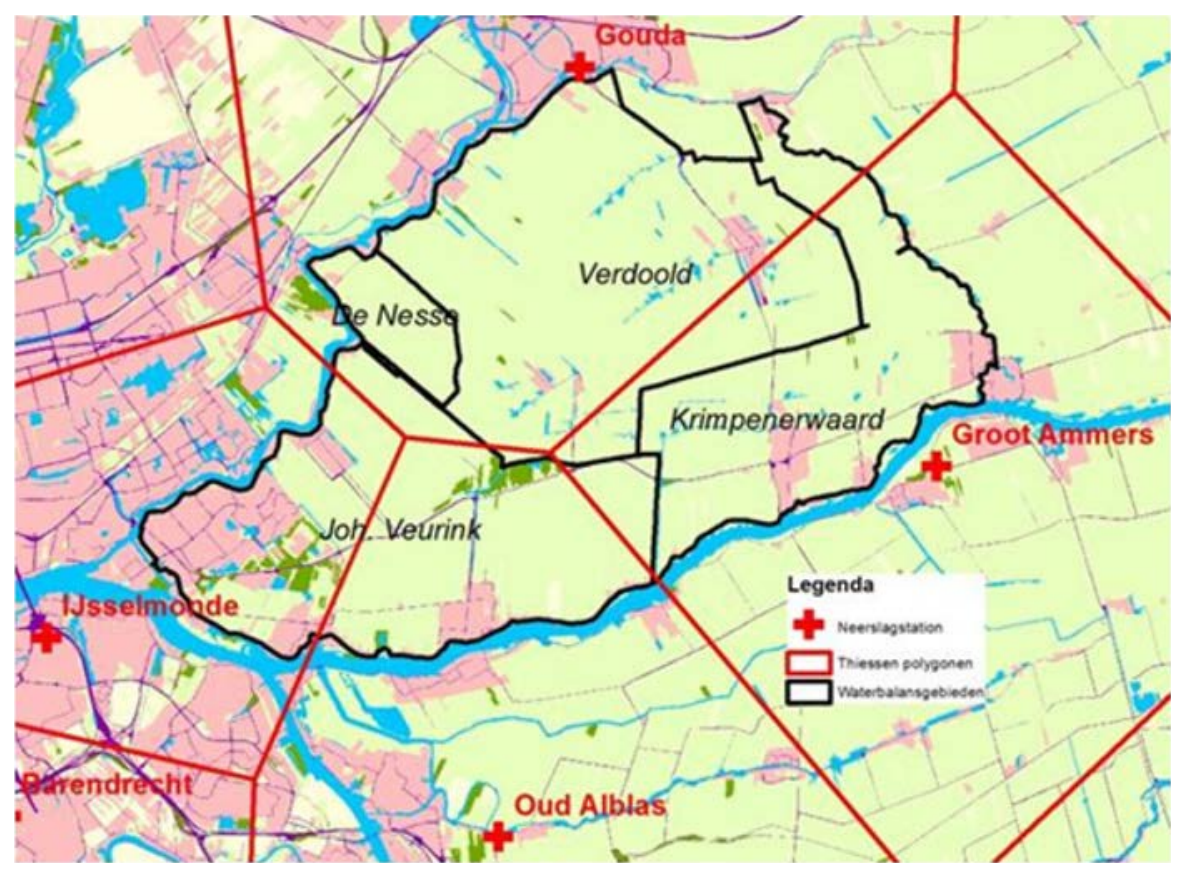

Figuur 2.4 Thiessennet op basis van KNMI-neerslagstations 


\subsection{Kwel en wegzijging}

Als resultaat van berekeningen met het model MORIA zijn twee kwelkaarten beschikbaar, nl. de zomerkwel en winterkwel. De winterkwel is weergegeven in Figuur 2.5. Voor het opzetten van de rekenplots waarmee de af- en uitspoeling wordt berekend, wordt rekening gehouden met de indeling in drie klassen. Voor de onderrandvoorwaarde (kwel/wegzijging onderzijde bodemprofiel) wordt uitgegaan van het seizoenverloop van de stijghoogten zoals die zijn gemeten in de diepe peilbuizen in het gebied.

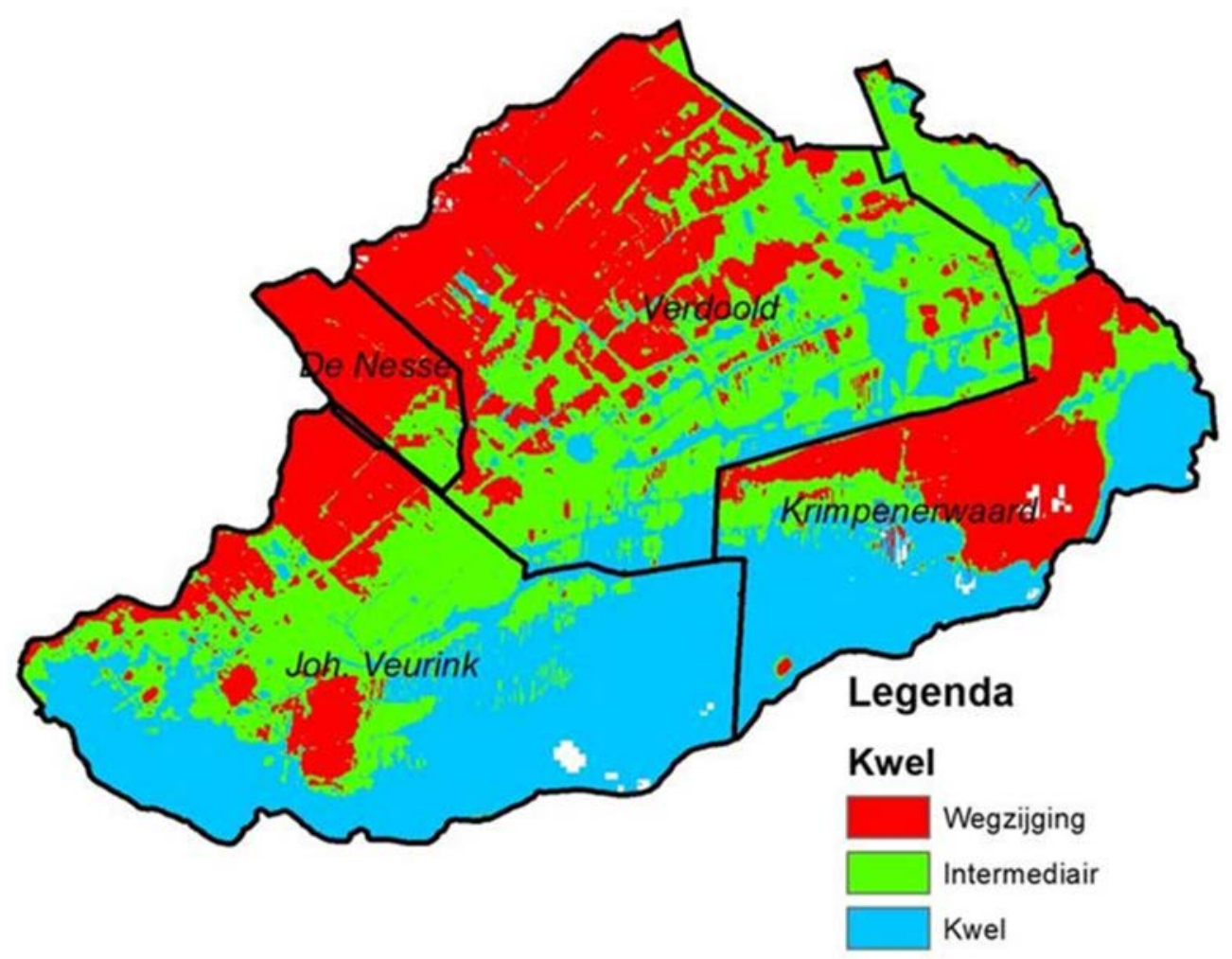

Figuur 2.5 Ruimtelijke ligging van de drie onderscheiden kwelklassen (winterkwel) 


\subsection{Polderpeilen en drooglegging}

De polderpeilen zijn weergegeven in Figuur 2.6. Deze peilen zijn in het zuiden langs de Lek het hoogst en nemen af met ruim een halve meter in het noorden van het gebied. De huidige drooglegging is weergegeven in Figuur 2.7. Langs de grenzen en het bebouwde gebied is de drooglegging het grootst. Ruim twee derde (67\%) van het areaal waarmee in deze studie wordt gerekend, heeft een drooglegging van 46 à $50 \mathrm{~cm} ; 17 \%$ een drooglegging van $51-55 \mathrm{~cm}, 10 \%$ een drooglegging van 56 à $60 \mathrm{~cm}$ en $7 \%>60 \mathrm{~cm}$.

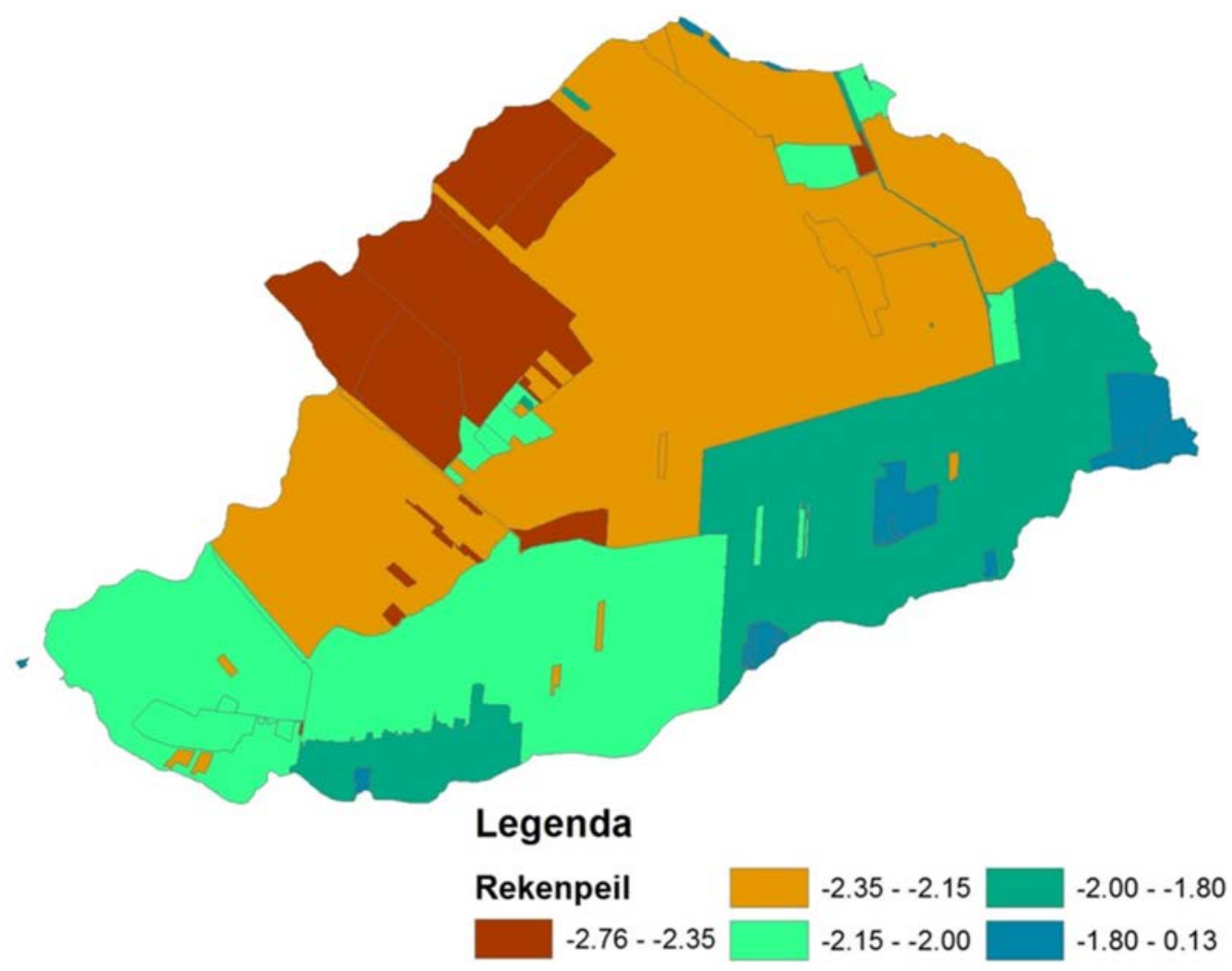

Figuur 2.6 Peilgebieden met de bijbehorende polderpeilen en afwijkingen daarop

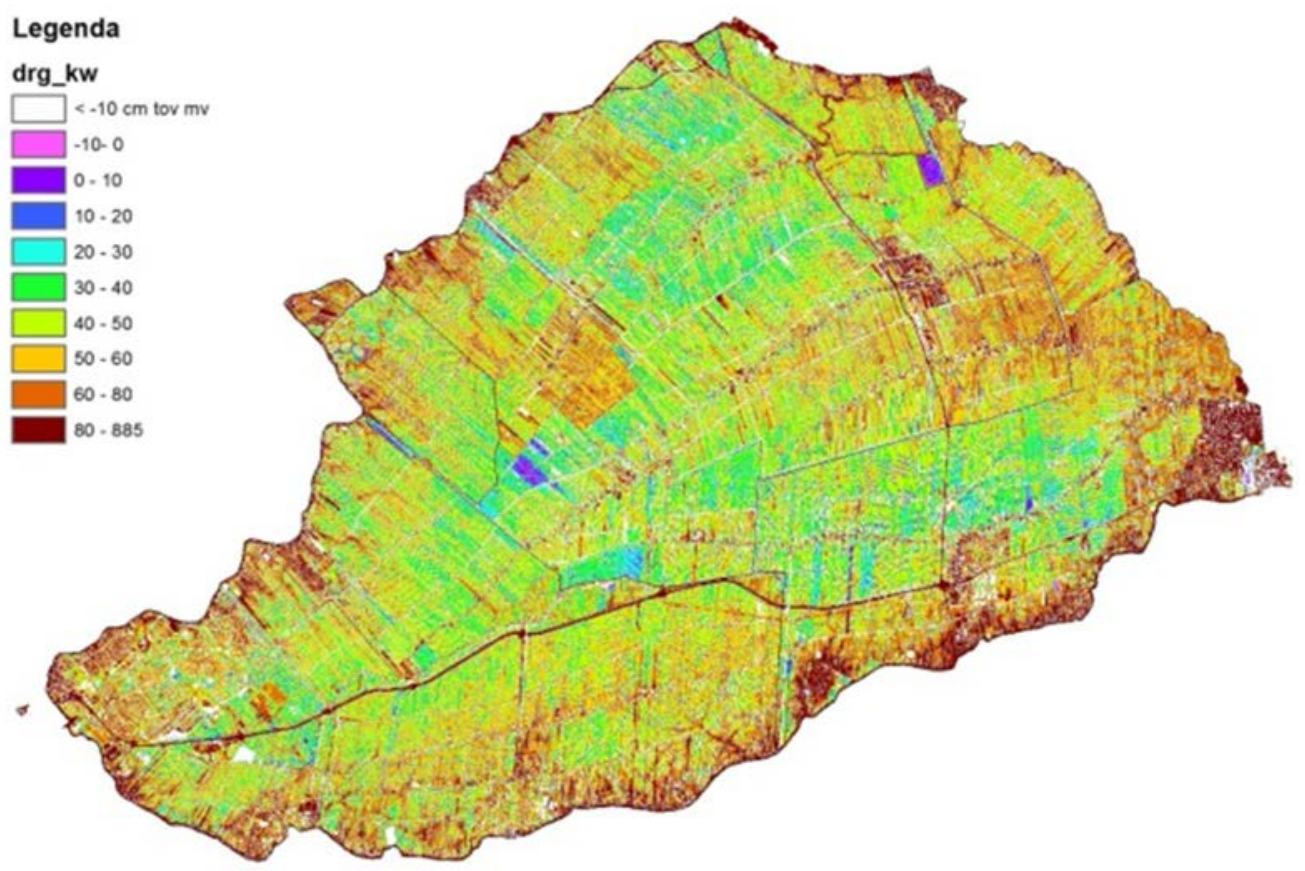

Figur 2.7 Gemiddelde drooglegging 


\subsection{In- en uitlaat}

De in- en uitlaatpunten zijn weergegeven in Tabel 2.3 en Figuur 2.8. De debieten vanaf 1997 op deze punten zijn op dagbasis aangeleverd door het Hoogheemraadschap. De hieruit gesommeerde jaartotalen per waterbalanseenheid zijn weergegeven in Figuur 2.9a en Figuur 2.9b.

Uit deze in- en uitlaatgegevens komt naar voren dat in Nesse structureel meer water wordt ingelaten dan wordt uitgemalen. In de Krimpenerwaard wordt ongeveer evenveel water in- als uitgelaten. Voor de andere twee gebieden wordt structureel meer water uitgelaten dan ingelaten. Bij de interpretatie van de inlaatdebieten en vrachten moet worden bedacht dat in deelgebied Krimpenerwaard vooral water vanuit de Lek wordt ingelaten. In de andere drie deelgebieden wordt geen rivierwater ingelaten, maar is sprake van doorvoerwater vanuit de Krimpenerwaard.

\section{Tabel 2.3}

In- en uitlaatpunten

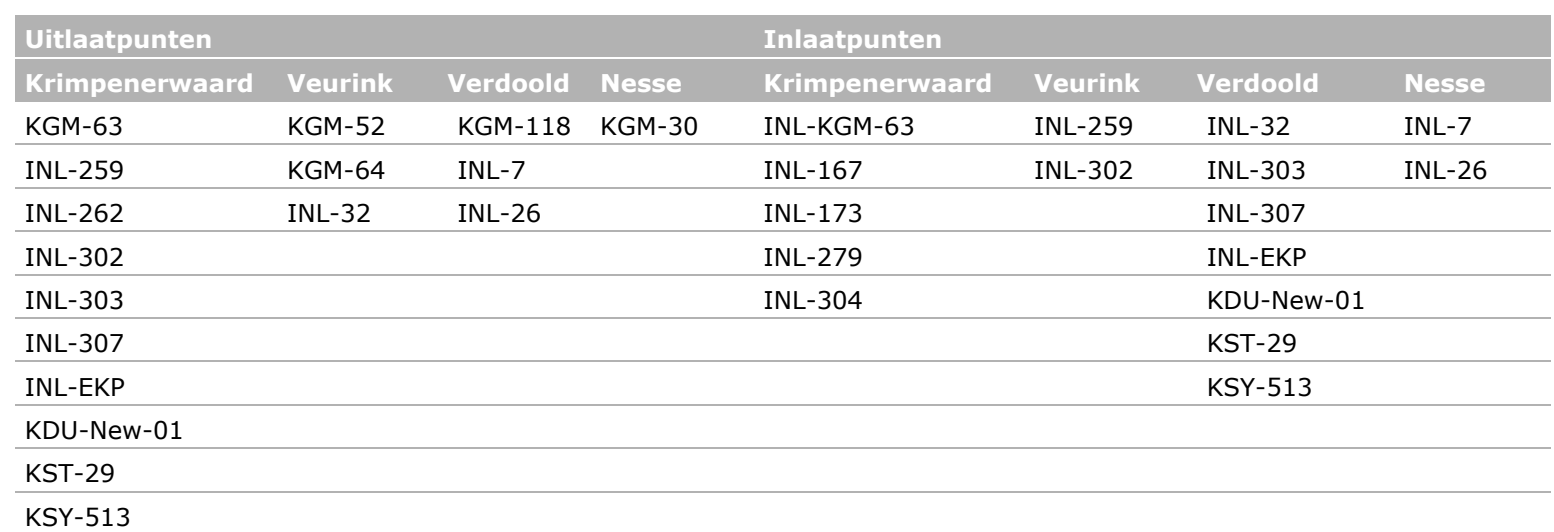

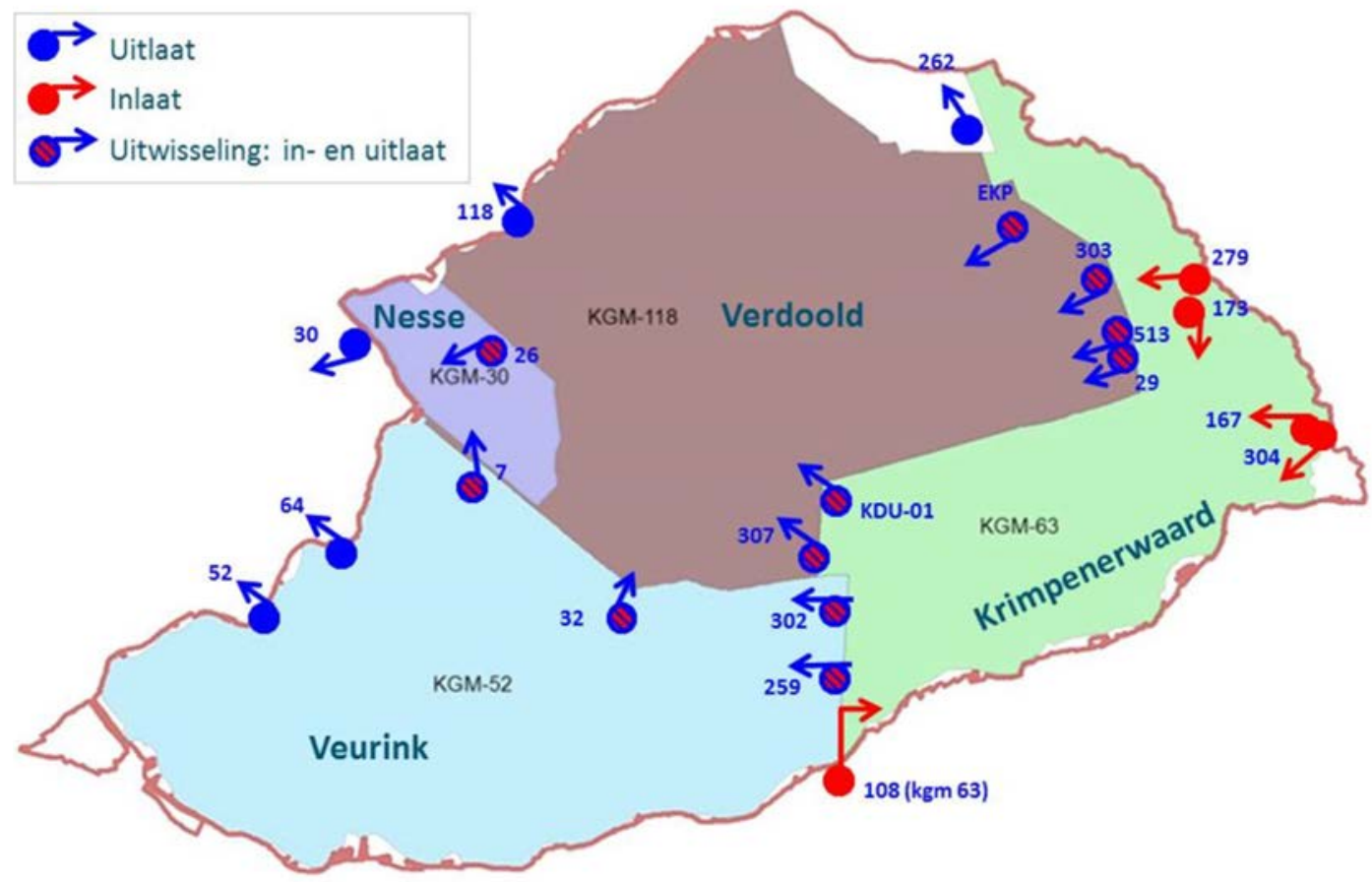

Figuur 2.8 Overzicht in- en uitlaatpunten van de vier waterbalansgebieden 

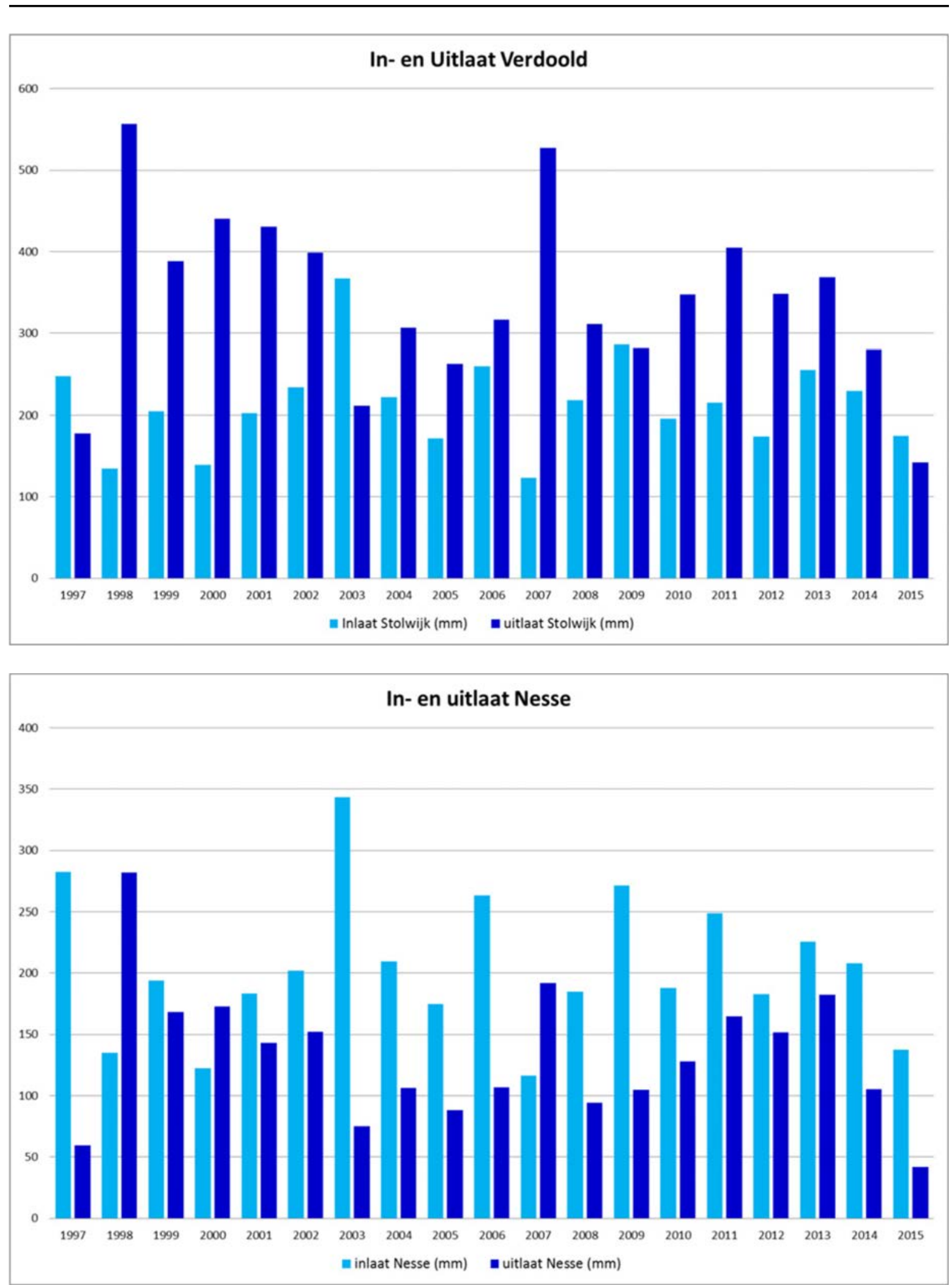

Figuur 2.9a Overzicht jaarlijkse in- en uitlaat per deelgebied (Verdoold, Nesse) 

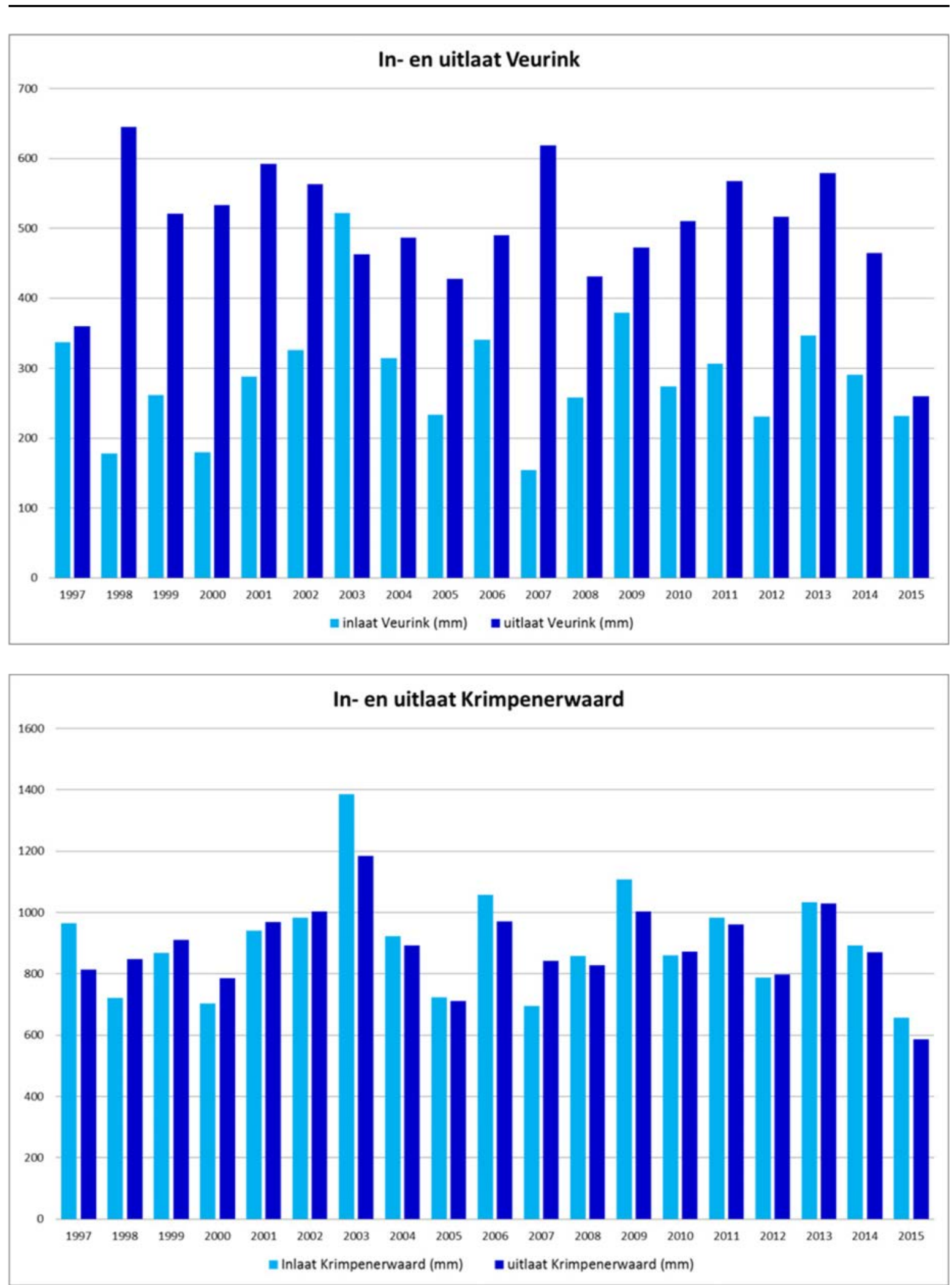

Figuur 2.9b Overzicht jaarlijkse in- en uitlaat per deelgebied (Veurink, Krimpenerwaard) 


\section{Modelopzet en -uitgangspunten}

\section{$3.1 \quad$ Inleiding}

Voor het ontrafelen van de nutriëntenbronnen van het oppervlaktewater en het daaruit kwantificeren van de achtergrondbelasting zijn water- en stofbalansen (stikstof en fosfor) opgesteld. Deze balansen zijn opgezet op het niveau van de vier onderscheiden deelgebieden. In dit hoofdstuk worden de modelopzet en de uitgangspunten beschreven.

\subsection{Opzetten rekenplots uit- en afspoeling}

Om de nutriëntenbronnen te ontrafelen, is vooral de diffuse af- en uitspoeling vanuit het landelijk gebied belangrijk. Om deze diffuse belasting te kunnen kwantificeren en de achterliggende bronnen te kunnen ontrafelen, wordt gerekend met het modelconcept SWAP-ANIMO. Deze modelkoppeling vormt ook de basis van het modelinstrumentarium STONE, dat wordt ingezet voor de evaluatie van de mestwetgeving en de evaluatie van de Kaderrichtlijn Water (ex ante- en ex post-evaluaties). Met SWAP-ANIMO worden op dagbasis eendimensionale bodemprofielen doorgerekend qua vochthuishouding en nutriëntenhuishouding. Op landelijk niveau is het landelijke gebied daarbij ingedeeld in 6405 verschillende rekenplots die verschillen qua bodemtype, grondwatertrappen, landgebruik, kwel, en meteo-regio.

Voor de onderhavige studie is gekozen om niet uit te gaan van de STONE rekenplots, maar om nieuwe rekenplots op te zetten die specifiek representatief zijn voor het veenweidegebied van de Krimpenerwaard. In de voorgaande detailstudie Monitoring Stroomgebieden waren drie rekenplots opgezet, rekening houdend met de drie meest onderscheidende bodemtypen: waardveen, koopveen en drechtvaaggronden. Nu is een nieuwe indeling gemaakt, waarmee naast deze drie verschillende bodemtypen ook onderscheid is gemaakt in meteo, kwel en landgebruik. Deze kenmerken en resulterende plotindeling worden in het navolgende behandeld.

\section{Bodem}

Zoals aangegeven in Tabel 2.3, vertegenwoordigen drie bodems samen verreweg het grootste deel van het areaal, $\mathrm{nl}$. 98\% van de Krimpenerwaard wanneer geen rekening wordt gehouden met stedelijk gebied en water. Analoog aan de studie die is uitgevoerd voor monitoring stroomgebieden zijn deze drie bodemeenheden aangehouden voor de indeling in rekenplots.

\section{Meteo}

Als gekeken worden naar het Thiessennet van de KNMI-stations (Figuur 2.4) en de ligging van de vier waterbalanseenheden, ligt het voor de hand om voor de waterbalanseenheden, en dus ook de rekenplots die daar binnen vallen, de volgende meteostations aan te houden:

- Waterbalansgebied Verdoold en de Nesse: 443 Gouda

- waterbalansgebied Krimpenerwaard: 434 Groot Ammers

- waterbalansgebied Veurink: 465 Oud-Alblas

Een deel van de Thiessenpolygoon voor IJsselmonde valt over waterbalansgebied Veurink, maar omdat dit gebied sterk verstedelijkt is en veel van dit stedelijk gebied via de riolering naar buitenwater wordt afgevoerd, zijn de resterende gebieden toebedeeld aan Oud-Alblas. 


\section{Kwel en wegzijging}

Als resultaat van berekeningen met het model MORIA zijn twee kwelkaarten beschikbaar, nl. de zomerkwel en winterkwel. De kaart met de winterkwel is geclipt op basis van de vier waterbalansgebieden. Voor deze kaart zijn de statistieken bepaald op basis van de kwelwaarden in $\mathrm{mm} / \mathrm{d}$ (Tabel 3.1).

\section{Tabel 3.1}

Statistieken kwelkaart winter

\begin{tabular}{llllll} 
Kwel winter & Basiskaart & Na verwijdering extremen & Kenmerken onderscheiden kwelklassen \\
\cline { 3 - 6 } Aantal grids & 214.917 & 213.773 & 71.143 & 70.991 & 71.639 \\
\hline Minimum (mm/d) & $-63,074$ & $-2,465$ & 0,066 & $-0,03$ & $-2,465$ \\
\hline Maximum (mm/d) & 119,49 & 1,571 & 1,571 & 0,065 & $-0,031$ \\
\hline Gemiddeld (mm/d) & $-0,444$ & 0,009 & 0,266 & 0,012 & $-0,293$ \\
\hline Mediaan (mm/d & & 0.009 & & & \\
\hline Standaarddeviatie (mm/d) & 0,674 & 0,330 & & & \\
\hline
\end{tabular}

Uit Tabel 3.1 onder basiskaart volgt dat er extreme waarden, d.w.z. minstens vijf standaarddeviaties verwijderd van het gemiddelde, voorkomen. Voor uitbijters wordt aangehouden dat deze minstens drie standaarddeviaties verwijderd liggen van het gemiddelde. Omdat deze extremen/uitbijters het gemiddelde sterk kunnen beïnvloeden, is een nieuwe kaart gemaakt waarbij waarden groter dan drie standaarddeviaties verwijderd van het oorspronkelijk gemiddelde zijn verwijderd. De statistieken van de nieuwe kaart staan eveneens in Tabel 3.1 onder 'na verwijdering extremen' weergegeven. De verwijdering van 1198 gridcellen (ongeveer 0,5\%) heeft een aanzienlijk effect op het gemiddelde dat verandert van een wegzijging van $-0,44 \mathrm{~mm} / \mathrm{d}$ naar een lichte $\mathrm{kwel}$ van 0,009 mm/d. Het gemiddelde en de mediaan van de nieuwe kwelkaart zijn gelijk aan elkaar.

Voor de uiteindelijke indeling in plots is besloten om niet uit te gaan van een indeling in kwel, intermediair en wegzijging voor de gehele Krimpenerwaard, maar om deze indeling te verfijnen voor de drie meteogebieden, zoals weergegeven in Figuur 3.1. Hierbij moet worden bedacht dat de absolute niveaus van de kwel en wegzijging per deelgebied verschillend zijn (zie legenda in Figuur 3.1).

Voor de onderrandvoorwaarde wordt met SWAP niet gerekend met een vaste kwel, maar met een stijghoogteverloop in de tijd en een weerstand van de deklaag. Hiertoe is op basis van gemeten stijghoogten in de beschikbare peilbuizen een isohypsenkaart vervaardigd. Deze kaart is weergegeven in Figuur 3.2. Voor iedere rekenplot is op basis van deze kaart een gemiddelde stijghoogte afgeleid. Tevens is voor iedere peilbuislocatie een langjarige, gemiddelde fluctuatie over de seizoenen afgeleid. Deze dynamiek is additioneel aan de gemiddelde stijghoogte toebedeeld aan iedere rekenplot.

\section{Landgebruik}

Uitgaande van LGN7 wordt rekening gehouden met de hoofdindeling landbouw, water, stedelijk en natuur. Met SWAP-ANIMO wordt gerekend voor agrarisch grasland en natuurgrasland. In Figuur 3.3 is de ruimtelijke verdeling van grasland en natuurgrasland weergegeven. 

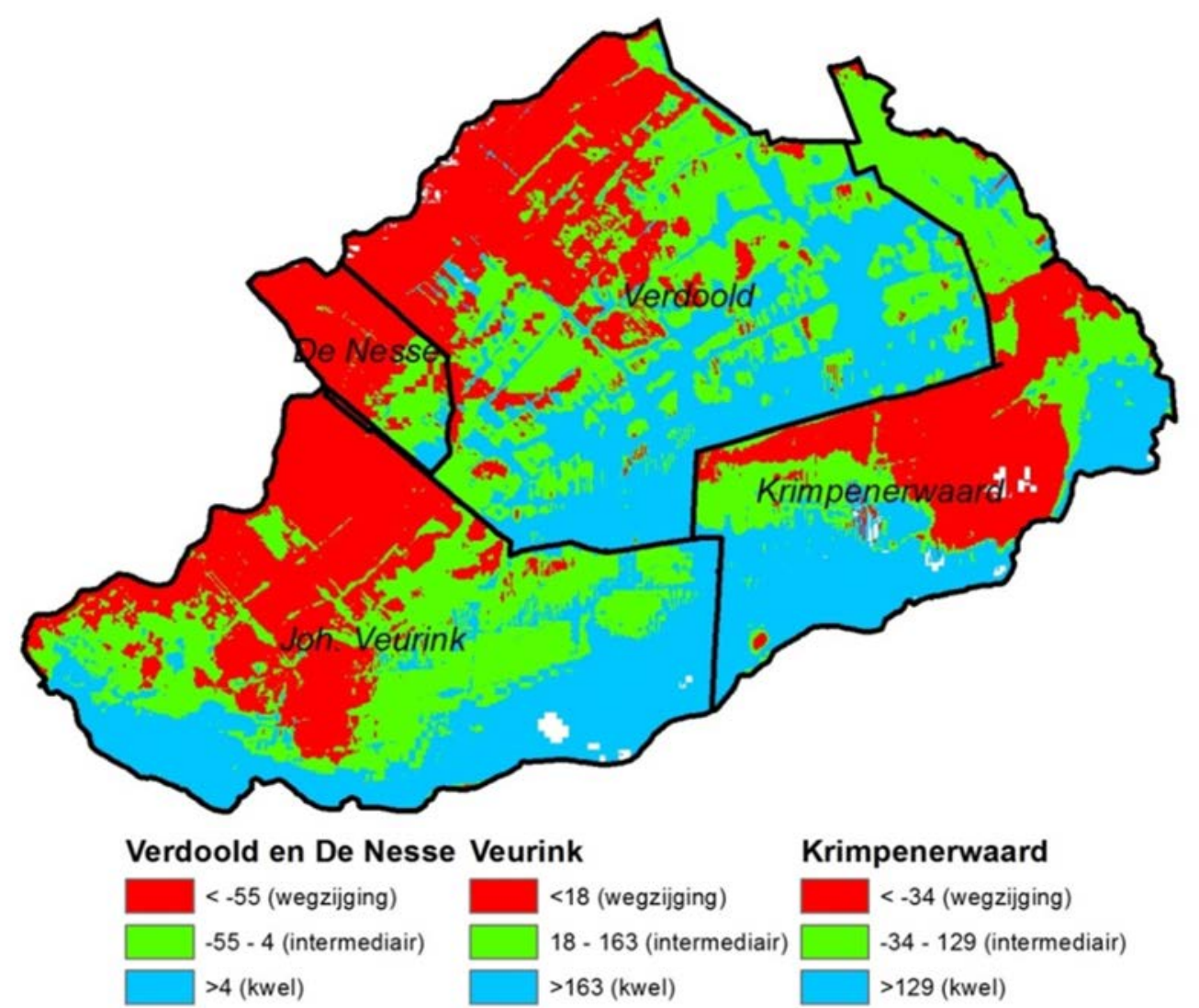

Krimpenerwaard

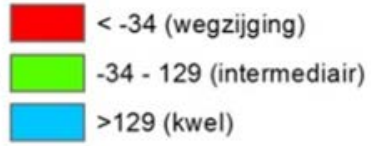

Figuur 3.1 Ruimtelijke ligging van de drie onderscheiden kwelklassen. Per deelgebied is de klassenindeling aangepast aan de spreiding van de kwel en wegzijging in het betreffende gebied

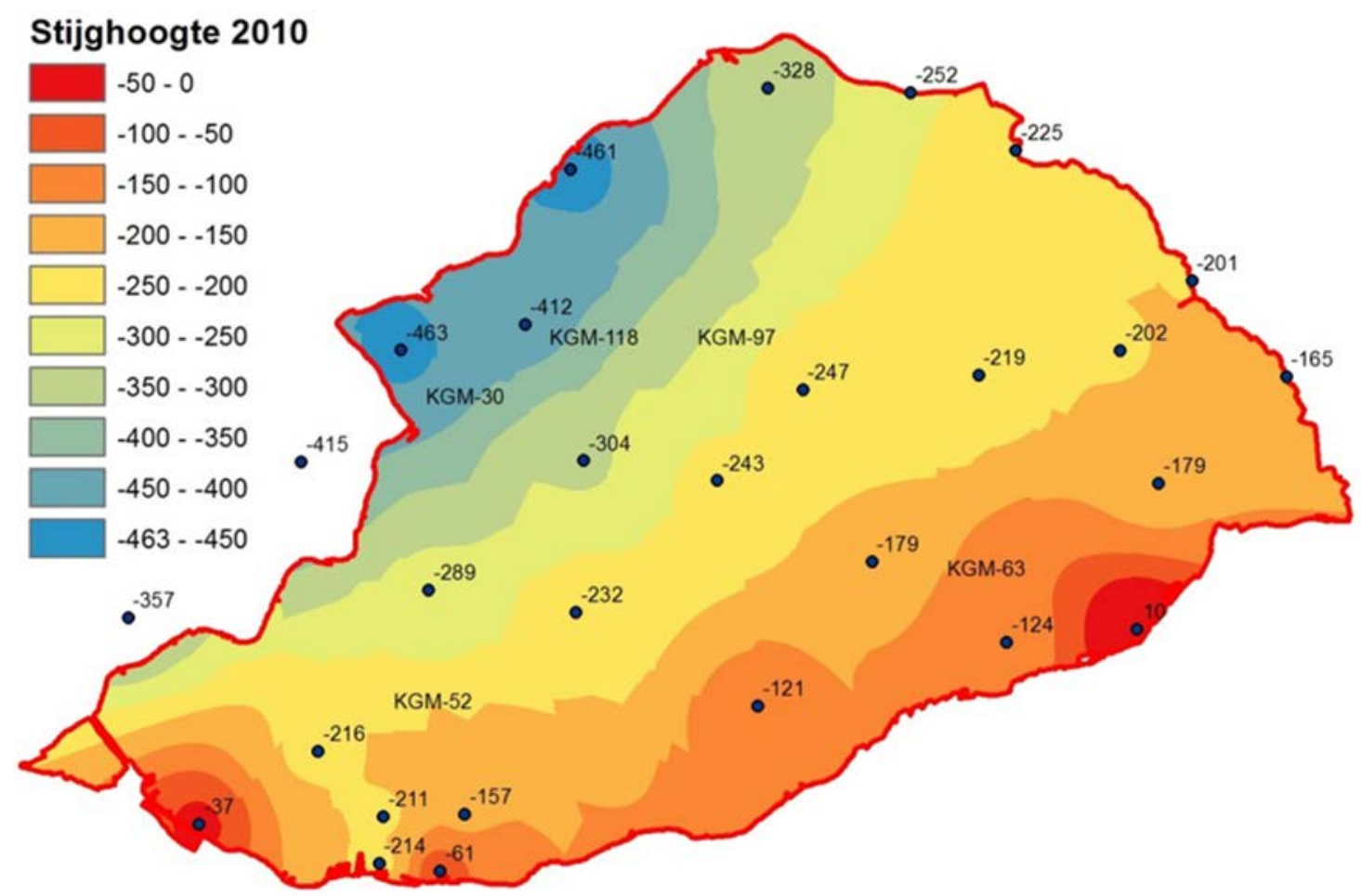

Figuur 3.2 Gemiddelde stijghoogte eerste watervoerende pakket, afgeleid uit de peilbuiswaarnemingen 


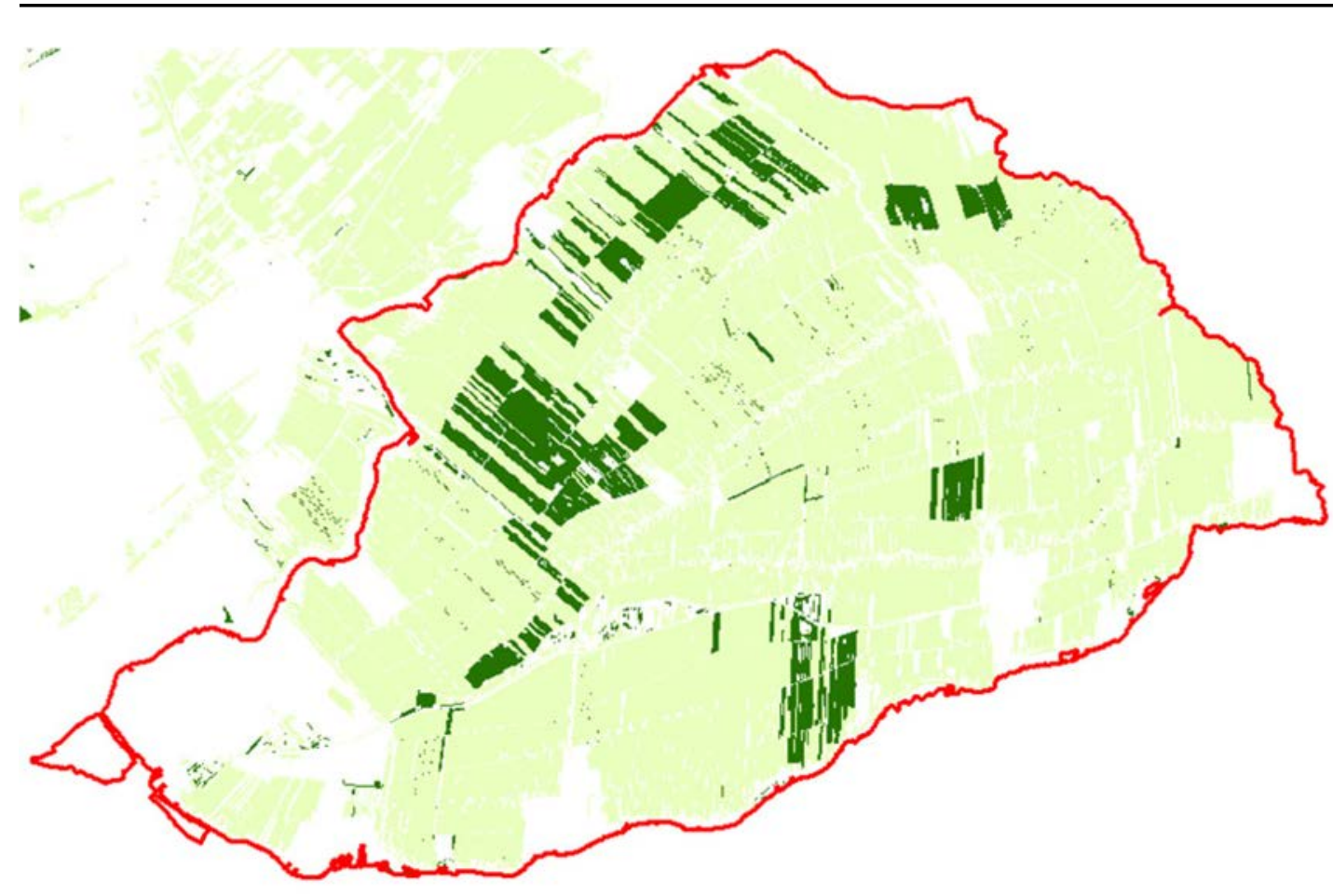

Figuur 3.3 Ruimtelijk ligging van agrarisch grasland (lichtgroen) en natuurgrasland (donker groen)

\subsection{Resulterende plotindeling}

Met de combinaties van de gebiedsspecifieke eigenschappen voor landgebruik, kwel, meteo en bodem zijn de rekenplots opgebouwd. De vier (GIS)kaarten zijn opgesplitst in drie klassen voor meteo, vier voor landgebruik (grasland, natuurgrasland, water en stedelijk); vier voor kwel (kwel, intermediair, wegzijging, extreme waarde/niet toebedeeld) en vijf voor bodem (drie veenbodems, water en stedelijk). Hiermee kunnen in principe 240 combinaties worden gemaakt. De vier kaarten zijn allereerst omgezet naar gridkaarten van $25 * 25 \mathrm{~m}$. Vervolgens zijn de kaarten gecombineerd tot de zogenaamde plots. Totaal worden 191 combinaties ofwel plots onderscheiden, die samen 13.435 ha beslaan. De plots variëren in grootte van 1.369 ha tot $<1$ ha.

Voor de modellering van de af- en uitspoeling is ernaar gestreefd om het aantal rekenplots niet te groot te laten worden. Daarbij is het niet zinvol om combinaties van bodem-landgebruik-hydrologie door te rekenen die slechts in kleine arealen voorkomen. Daarom is een minimumoppervlak van 100 ha aangehouden. De plots die kleiner zijn, beslaan in totaal $19 \%$ en betreffen voornamelijk bebouwd gebied ( $7 \%$ ) en natuurgrasland. Omdat veel van de natuurgraslandplots kleiner zijn dan 100 ha, zijn deze toebedeeld aan grasland (landbouw). Dit geeft voor de bemesting en resulterende uitspoeling geen vertekend resultaat, omdat ten behoeve van het rekenscenario natuur deze rekenplots voor beide landgebruiksvormen (landbouw en natuur) zijn doorgerekend.

De definitieve indeling resulteert in 21 rekenplots voor landbouw en natuur. De ligging hiervan is weergegeven in Figuur 3.4. In Bijlage 1 zijn de gebiedskenmerken van de 191 rekenplots opgenomen, evenals een overzichtstabel met de kenmerken van de 21 geselecteerde plots en een tabel met de eigenschappen (parameters) die aan de 21 rekenplots zijn toegekend. Naast deze 21 wordt in de berekening ook rekening gehouden met het areaal bebouwd en het areaal water. Voor bebouwd wordt aangenomen dat de helft verhard is en water hier via het rioolstelsel wordt afgevoerd naar buitenwater en dat het onverharde deel voor de waterafvoer opgevat kan worden als natuurgrasland (veelal groenvoorzieningen en parkjes). Voor open water wordt gerekend met de arealen die door HHSK zijn opgegeven. De resulterende arealen voor grasland en bebouwd zijn weergegeven in Tabel 3.2. 
Tabel 3.2

Arealen rekenplots grasland (landbouw), natuur en bebouwd gebied

\begin{tabular}{lllll} 
& Nesse & Veurink & Krimpenerwaard & Verdoold \\
Grasland (landbouw) & 279 & 2.494 & 2.036 & 3.406 \\
\hline Natuurgrasland & 158 & 330 & 184 & 329 \\
\hline Bebouwd & 41 & 1.178 & 484 & 374
\end{tabular}

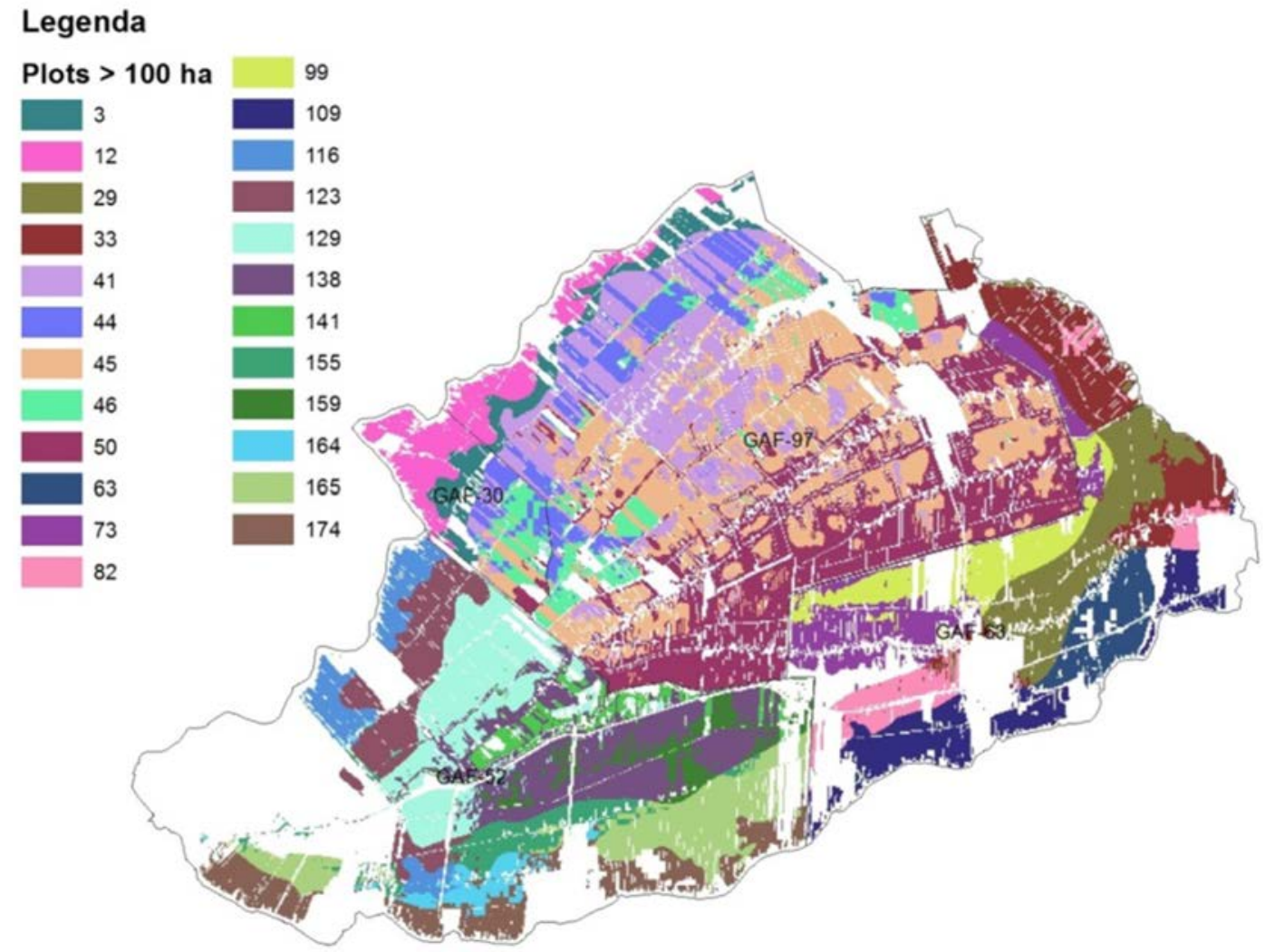

Figuur 3.4 Ligging van de 21 rekenplots waarmee de uit- en afspoeling is berekend

\subsection{Bemesting en gewasopame}

Voor het berekenen van de af- en uitspoeling van nutriënten zijn de aannames over het niveau van de bemesting én de gewasopname erg belangrijk. In deze studie is daarom kritisch gekeken wat hiervoor de aannames waren in de voorgaande studie Monitoring Stroomgebieden (MS). In Figuur 3.5 worden de mestgiften voor stikstof en de gewasopname zoals aangenomen in deze studie vergeleken met wat in STONE voor veenweide plots (koopveen) wordt aangehouden.
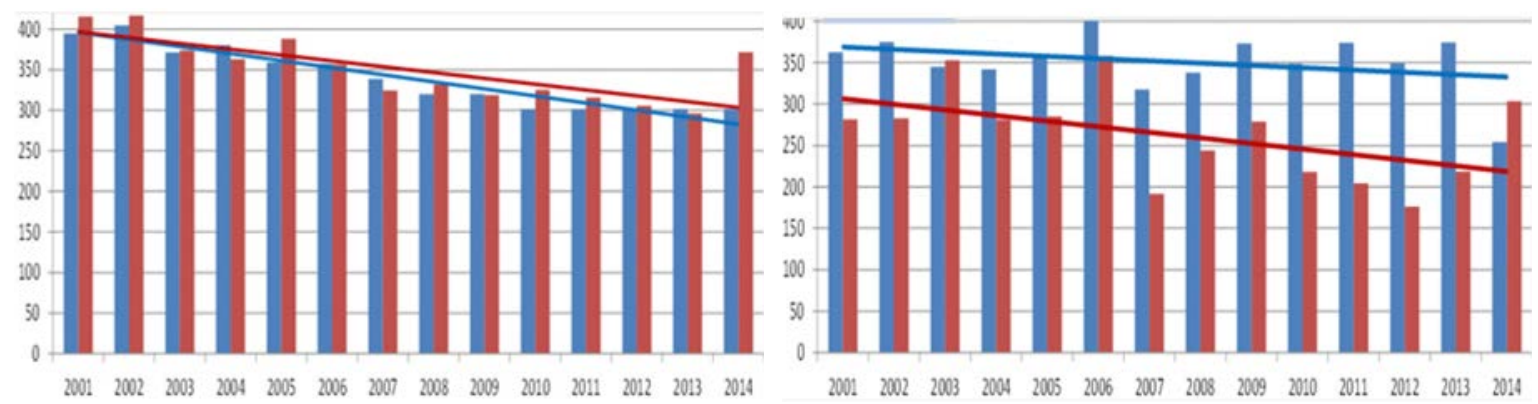

Figuur 3.5 N-bemesting (links) en gewasopname (rechts) in $\mathrm{kg} \mathrm{N} \mathrm{ha}^{-1}$ volgens Monitoring Stroomgebieden en STONE-plots koopveen Krimpenerwaard 
Uit Figuur 3.5 komt naar voren dat de mestgiften nagenoeg gelijk zijn, maar dat de gewasopname die wordt aangenomen in MS beduidend hoger is (gemiddeld $88 \mathrm{~kg} \mathrm{~N}$ per ha/jaar) dan de STONE-plots. De hoge gewasopname geeft in de helft van de jaren een negatief bemestingsoverschot (bemesting minus opname), terwijl dit volgens de gewasopname van STONE nagenoeg altijd positief blijft. Bij MS wordt dus meer onttrokken aan de bodem dan er mest wordt toegediend. Dit kan uit het veen komen, waarvan de mineralisatie bij deze drooglegging (ca. $50 \mathrm{~cm}$ ) 100-150 kg N per ha per jaar kan zijn (fig. 32 in Hendriks, 1991). Dit komt voor ca. 70\% ten goede aan het gewas (Hendriks, 1991). Dat kan het negatieve bemestingsoverschot dus ruim verklaren.

Om hier meer zekerheid over te verkrijgen, is de gewasopname vergeleken met resultaten van veldproeven in acht veenweidegebieden in West-Nederland waar de WUR (Idse Hoving) de effecten van onderwaterdrains op gewasproductie onderzoekt. Als de gewasopname wordt vergeleken met de veldproeven zonder drains, blijkt dat de gewasopname volgens MS dicht bij de praktijkgegevens van Idse Hoving te liggen. Daarom is voor de onderhavige studie gerekend met de gewasopname zoals die in $\mathrm{MS}$ is aangenomen.

Voor de aannames over de mestgiften is ook afgegaan op de praktijkkennis en gebiedskennis van PPP-Agro Advies, die de onderhavige studie mede heeft begeleid. De mestgiften die voor de landbouw graslanden waren aangehouden voor monitoring stroomgebieden sluiten goed aan bij de kennis van PPP-Agro Advies, met wel een kanttekening dat de laatste paar jaar de giften weer wat toenemen.

Op de natuurgraslanden, die in beheer zijn voor weidevogels, wordt ook dierlijke mest toegepast. Afgaand op de gegevens van HHSK en PPP-agro, zijn de dierlijke mestgiften hier ongeveer $65 \%$ ten opzichte van de hoeveelheden die op de landbouw graslanden worden toegepast.

Voor de mestgiften zijn de giften aangehouden zoals aangegeven in Tabel 3.3. Voor de periode vanaf 2015 wordt (conform de wetgeving) aangehouden dat er geen fosfaat kunstmest meer wordt toegepast. Voor de weidevogel graslanden wordt aangehouden dat om het jaar een grote en kleine gift wordt toegepast. Voor de overige natuur graslanden wordt uitgegaan dat deze niet worden bemest.

\section{Tabel 3.3}

Mestgiften ( $\mathrm{kg} \mathrm{ha}^{-1}$ ) landbouw- en natuurgraslanden zoals aangehouden in de modelberekeningen van de huidige situatie (2000-2014) en de toekomstige situatie (scenario's)

\begin{tabular}{|c|c|c|c|c|c|c|c|}
\hline \multirow[b]{3}{*}{ Jaar } & \multicolumn{4}{|c|}{ Landbouw graslanden } & \multicolumn{3}{|c|}{ Weidevogel natuurgraslanden } \\
\hline & \multicolumn{2}{|l|}{ Stikstof } & \multicolumn{3}{|l|}{ Fosfor } & \multirow{2}{*}{$\begin{array}{l}\text { Stikstof } \\
\text { Dierlijk }\end{array}$} & \multirow{2}{*}{$\begin{array}{l}\text { fosfor } \\
\text { Dierlijk }\end{array}$} \\
\hline & Dierlijk & Kunstmest & Dierlijk & Kunstmest & Jaar & & \\
\hline 2001 & 266 & 129 & 45,6 & 1,6 & 2001 & 184 & 27,9 \\
\hline 2002 & 278 & 127 & 39,3 & 1,3 & 2002 & 184 & 27,9 \\
\hline 2004 & 267 & 113 & 40,4 & 1,9 & 2004 & 184 & 27,9 \\
\hline 2005 & 242 & 117 & 36,8 & 1,9 & 2005 & 184 & 27,9 \\
\hline 2006 & 248 & 110 & 35,2 & 1,4 & 2006 & 184 & 27,9 \\
\hline 2007 & 235 & 104 & 33,3 & 1,3 & 2007 & 184 & 27,9 \\
\hline 2011 & 216 & 92 & 33,0 & 1,2 & 2011 & 184 & 27,9 \\
\hline 2012 & 230 & 92 & 35,0 & 1,2 & 2012 & 184 & 27,9 \\
\hline 2013 & 237 & 92 & 36,0 & 1,2 & 2013 & 184 & 27,9 \\
\hline 2014 & 244 & 96 & 35,0 & 1,0 & 2014 & 184 & 27,9 \\
\hline \multirow[t]{5}{*}{$2015-2029$} & 244 & 96 & 35,0 & 0,0 & 2015 & 146 & 22,4 \\
\hline & & & & & 2016 & 69 & 11,3 \\
\hline & & & & & 2017 & 146 & 22,4 \\
\hline & & & & & 2018 & 69 & 11,3 \\
\hline & & & & & Etc. & & \\
\hline
\end{tabular}




\subsection{Inlaat en uitlaat}

In paragraaf 2.7 is een overzicht gegeven van de in- en uitlaatpunten voor de vier onderscheiden deelgebieden. Het afleiden van de inkomende en uitgaande vracht per deelgebied wordt gedaan door de hoeveelheid inlaatwater te vermenigvuldigen met gemeten nutriëntenconcentraties in het inlaatwater en uitlaatwater. De debieten (op dagbasis) zijn door het hoogheemraadschap voor elk deelgebied aangeleverd. Vervolgens heeft het hoogheemraadschap representatieve meetlocaties gezocht voor kwaliteit van het inlaatwater en uitgeslagen water (Tabel 3.4).

\section{Tabel 3.4}

Overzicht meetpunten (debiet en kwaliteit) voor afleiding van inkomende en uitgaande nutriëntenvracht

\begin{tabular}{|c|c|c|c|}
\hline Deelgebied & & Debiet & Kwaliteit \\
\hline \multirow[t]{2}{*}{ Nesse } & Inlaat & INL-7, INL-26 & Inlet nr. 7, inlet nr. $26^{1)}$ \\
\hline & Uitlaat & KGM-30 & KOP301 \\
\hline \multirow[t]{2}{*}{ Veurink } & Inlaat & INL-259, INL-302 & LEK ${ }^{2)}$ \\
\hline & Uitlaat & INL32, KGM-52, KGM-64 & KOP1035 (KOP10013), KOP0201, Loetbos ${ }^{4)}$ \\
\hline \multirow[t]{2}{*}{ Krimpenerwaard } & Inlaat & INL-KGM63，INL-167，INL-176，INL-279，INL-304 & LEK ${ }^{2)}$, Vlist ${ }^{5)}$ \\
\hline & Uitlaat & $\begin{array}{l}\text { KGM-63, INL-262, INL-259, INL-302, INL-307, } \\
\text { KDU-NEW-01, KST-29, KSY-513, INL-EKP, INL-303 }\end{array}$ & Bergvliet ${ }^{6)}$, Bergambacht ${ }^{7)}$, KOP0801 \\
\hline \multirow[t]{2}{*}{ Verdoold } & Inlaat & $\begin{array}{l}\text { INL-32, INL-307, KDU-NEW-01, KST-29, KSY-513, } \\
\text { INL-EKP, INL-303 }\end{array}$ & Bergvliet ${ }^{6)}$, Bergambacht ${ }^{7)}$, Loetbos ${ }^{4)}$ \\
\hline & Uitlaat & INL-7, INL-26, KGM-118 & KOP0427 \\
\hline \multicolumn{4}{|c|}{ 1) Gemiddelde N- en P-concentratie per maand op basis van de meetpunten KOP0309 en KOP0310 } \\
\hline \multicolumn{4}{|c|}{ 2) Gemiddelde N- en P-concentratie per jaar op basis van meetpunten in de Lek } \\
\hline \multicolumn{4}{|c|}{ 3) Voor de periode $2000-2004$ is gebruikgemaakt van KOP1001, voor $2005-2014$ is KOP1035 gebruikt } \\
\hline \multicolumn{4}{|c|}{ 4) Gemiddelde N- en P-concentraties per maand } \\
\hline \multicolumn{4}{|c|}{ 5) Gemiddelde N- en P-concentratie per maand op basis van de meetpunten EO17 en EO19 } \\
\hline
\end{tabular}

Voor de kwaliteit van het uitgeslagen water zijn de werkelijk gemeten nutriëntenconcentraties gebruikt nabij de gemalen. De nutriëntenconcentraties worden over het algemeen tweewekelijks of maandelijks gemeten en voor de totale balansperiode (2000-2014) beschikbaar. Om de meetwaarden van de nutriëntenconcentraties op te schalen in tijd, wordt een lineaire interpolatie gedaan tussen twee meetwaarden om op die wijze een dagelijkse nutriëntenconcentratie te bepalen.

Het vinden van representatieve meetpunten voor het afleiden van de inkomende vracht is lastiger. De meetlocaties die in aanmerking komen, zijn suboptimaal, omdat de meetlocaties niet op de juiste plaats liggen (ver van inlaat- of uitlaat), niet jaarlijks bemonsterd worden dan wel slechts een beperkt aantal jaren binnen de periode 2000-2014 zijn bemeten. In overleg met het hoogheemraadschap is ervoor gekozen om een aantal basiswaarden te hanteren op basis van de belangrijkste beschikbare metingen. Deze basiswaarden zijn gemiddelde maandelijkse stikstof- en fosforconcentraties. Voor alle jaren worden dezelfde maandelijkse waarden aangehouden. Vervolgens wordt de inkomende vracht op dezelfde wijze afgeleid als voor de uitlaat (lineaire interpolatie).

Voor ieder afzonderlijk deelgebied is op deze wijze de belasting via inlaatwater berekend. Tabel 3.5 geeft een overzicht van de vrachten en debietgemiddelde concentraties van de inlaatpunten. Uit deze tabel blijkt dat een belangrijk deel (ongeveer de helft) van de totale belasting van inlaatwater afkomstig is van de omliggende rivieren, de Lek en de Vlist. De debietgemiddelde concentraties van het buitenwater zijn voor fosfor beduidend lager (schoner) dan het inlaatwater dat via het ene naar het andere deelgebied wordt doorgevoerd. Dit betekent dat dit water flink wordt opgeladen door de interne bronnen. Verder valt op dat het water uit de Lek een duidelijk andere samenstelling heeft dan de Vlist, namelijk wat hogere stikstofconcentraties en veel lagere fosforconcentraties. 
Tabel 3.5

Vrachten en debietgemiddelde concentraties inlaatwater inlaatpunten, geordend per deelgebied en totalen van het ingelaten rivier- en doorvoerwater

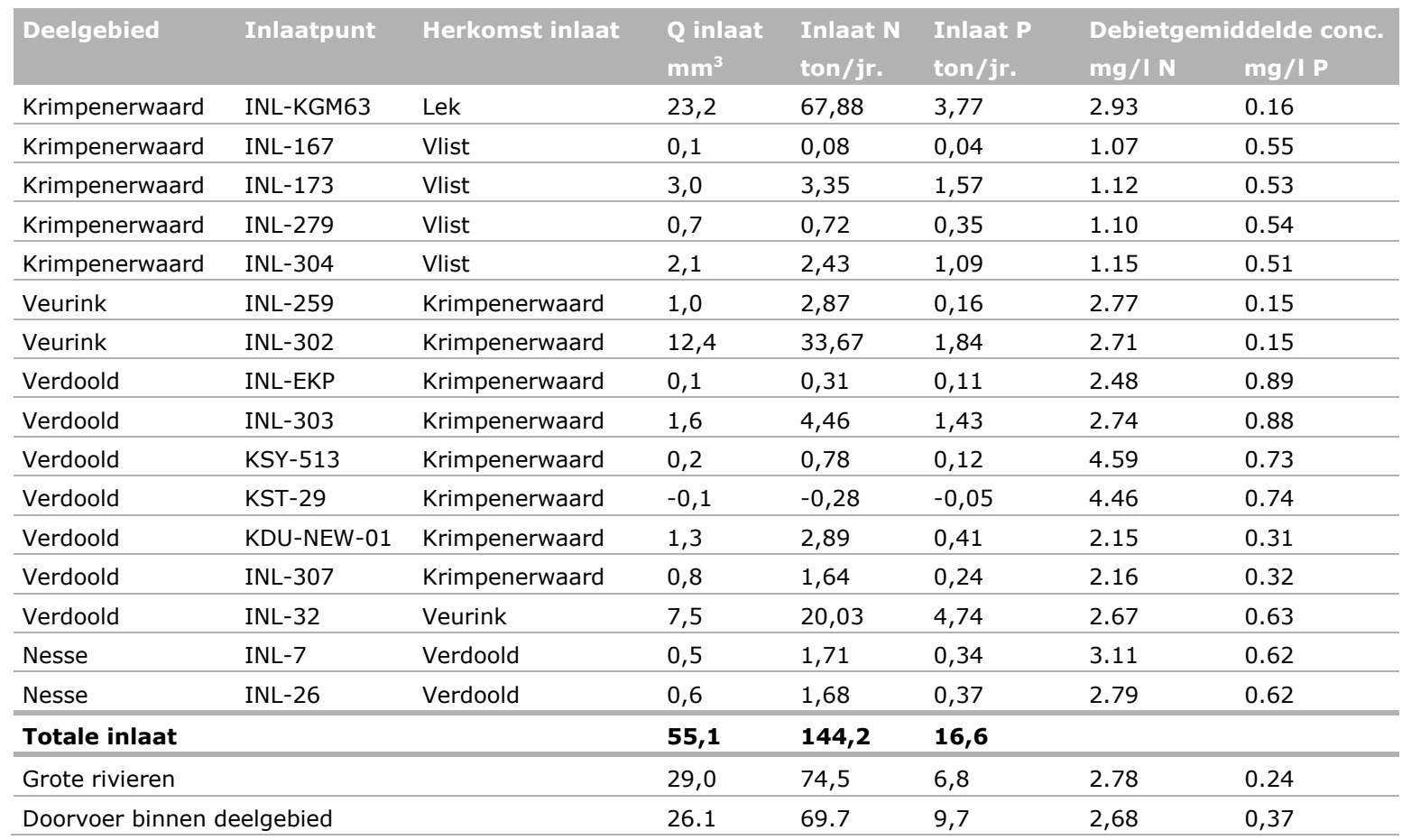

\subsection{Overige bronnen}

In de vorige paragrafen is de werkwijze besproken voor het afleiden van de uit- en afspoeling vanuit landbouw- en natuurgebieden en de inkomende en uitgaande vracht. Naast deze belasting wordt het oppervlaktewater ook belast via een aantal andere bronnen. De bijdrage van deze bronnen aan de nutriëntenbelasting van het oppervlaktewater wordt afgeleid conform de ECHO-methodiek (Kroes et al., 2011). Een overzicht van deze bronnen is in Tabel 3.6 weergegeven.

Tabel 3.6

Overzicht van de overige bronnen en de herkomst van deze informatie

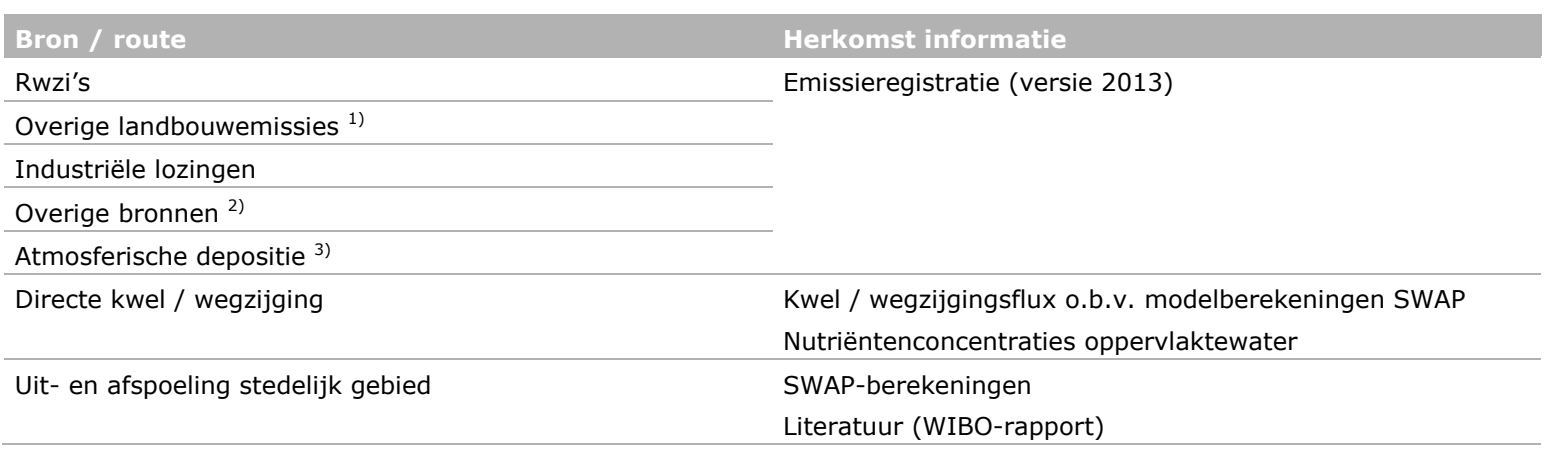

1) o.a. meemesten sloten, glastuinbouw, erafspoeling

2) o.a. huishoudelijk afval, ongerioleerde lozingen, verkeer, vervoer

3) atmosferische depositie open water 
De stikstof- en fosforbelasting van het oppervlaktewater via de directe kwel en de wegzijging vanuit het oppervlaktewater naar het grondwater is afgeleid op basis van het areaal open water, de kwel of wegzijgingsflux en bijbehorende concentraties. Het areaal open water is door het hoogheemraadschap aangeleverd. Voor het schatten van de gebiedsgemiddelde kwel- of wegzijgingsflux wordt gebruikgemaakt van SWAP-berekeningen. Voor de nutriëntenconcentraties zijn de gemeten concentraties in het oppervlaktewater gebruikt.

In deze studie is ook de uit- en afspoeling vanuit stedelijk gebied meegenomen. Hierbij is aangenomen dat $50 \%$ via de rioolpersleidingen naar het buitenwater gaat. Voor de andere $50 \%$ (recreatief/onverhard gebied) wordt de uit- en afspoelingsflux van een recreatief grasplot overgenomen. Bijgaande emissies van $\mathrm{N}$ en $\mathrm{P}$ zijn afgeleid uit literatuur (recente studie Witteveen en Bos).

Bij controle van de atmosferische stikstofdepositie getallen is geconstateerd dat in EmissieRegistratie wordt uitgegaan van een open water oppervlak van circa 7\%. Deze getallen zijn naar boven toe bijgesteld naar rato van de in de onderhavige studie aangehouden arealen open water.

\subsection{Retentie}

Retentie in het oppervlaktewater staat voor het verwijderen en vastleggen van nutriënten in de waterlopen. Dit kan door tijdelijke en permanente opslag in onder andere waterplanten en in de waterbodem en/of door gasvormige emissies naar de atmosfeer (denitrificatie).

De retentie is geschat conform de werkwijze die is gehanteerd binnen de Evaluatie Meststoffenwet 2012 (Van Boekel et al., 2012) en in de studie voor HHNK bij het afleiden van theoretische achtergrondconcentraties (Van Boekel et al., 2015). In Bijlage 2 is een uitgebreidere beschrijving van de methode gegeven. De belangrijkste uitganspunten zijn:

- De grootte van deze retentieprocessen is voor stikstof afgeleid uit metingen (PLONS-project, www.plons.wur.nl). Op basis van de eigenschappen van de polders is de capaciteit van het oppervlaktewatersysteem bepaald om stikstof vast te leggen, uitgedrukt in gram per $\mathrm{m}^{2}$ waterbodem. De zo berekende absolute stikstofretentie is van toepassing voor alle nutriëntenbronnen in polders met voornamelijk klei of veen in de ondergrond.

- Voor de fosforretentie in poldersystemen zijn dezelfde retentiefactoren aangehouden die zijn gehanteerd bij de evaluatie van de Meststoffenwet (Van Boekel et al., 2012). Voor de uit- en afspoeling is een vaste retentiefactor gebruikt van 0,5 en voor de andere bronnen is een vaste retentiefactor van 0,2 aangehouden.

- Voor de puntbronnen wordt bij de berekening van de retentie rekening gehouden met de locatie van de puntbron. Voor een puntbron die loost nabij het uitstroompunt wordt een lagere retentie berekend als een puntbron die meer bovenstrooms in de polder loost.

Uit de berekening van de stoffenbalans bleek dat de retentie voor stikstof volgens deze werkwijze circa 15 à $25 \%$ bedraagt ten opzichte van de totale inkomende vracht, terwijl in de studie Monitoring Stroomgebieden (van Gerven, 2011) een retentie met een oppervlaktewaterkwaliteit model was afgeleid van circa 50\%. Omdat in Monitoring Stroomgebieden hier met meer detail naar is gekeken en dit ook berekend is met een oppervlaktewater kwaliteitsmodel, is voor stikstof een retentie van $50 \%$ aangehouden. Voor fosfor wordt met $\mathrm{ECHO}$ een retentie voor de diffuse bronnen berekend van $50 \%$ en $20 \%$ voor inlaat en puntbronnen (hier de rwzi). Dit komt goed overeen met de retentie zoals die voor fosfor in Monitoring Stroomgebieden was afgeleid. 


\subsection{Modellering en toetsing water- en stoffenbalans}

Voor de water- en stofbalans wordt uitgegaan van de indeling in de vier deelgebieden. Allereerst is per deelgebied de waterbalans berekend, volgens de in Figuur 3.6 aangegeven schema's.

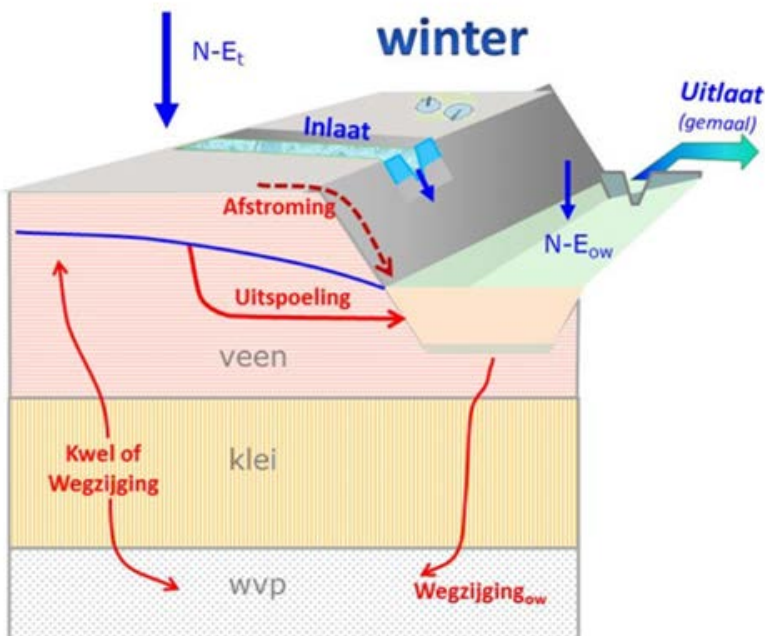

Uitlaat winter $=$

af- en uitspoeling - wegzijging $_{o w}+\mathrm{N}-\mathrm{E}_{\mathrm{ow}}+$ inlaat

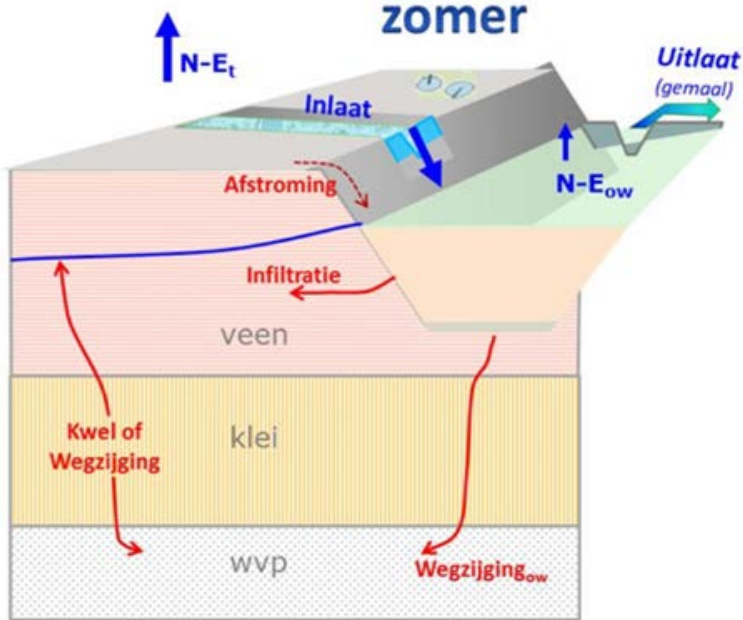

Uitlaat zomer $=$

afstroming - infiltratie - wegzijging $_{\mathrm{ow}}+\mathrm{N}-\mathrm{E}_{\mathrm{ow}}+$ inlaat

Figuur 3.6 Schematische weergave berekening waterbalans winter- (links) en zomerperiode (rechts)

Voor ieder deelgebied wordt voor het inlaatwater uitgegaan van de door HHSK aangeleverde debieten. Vanuit de meteocijfers zijn de neerslag en verdamping op open water berekend.

Met SWAP-WOFOST is de af- en uitspoeling berekend. In de zomer wordt door de relatief hoge waterpeilen veelal een negatieve uitspoeling berekend. Dit wordt aangeduid als infiltratie. Met de SWAP-WoFOST modellen is voor de onderrandvoorwaarde de stijghoogte van het watervoerende pakket genomen vanuit de voor dit project gegenereerde isohypsenkaart en daarop gesuperponeerd de seizoenvariatie van de stijghoogten. Voor de hydraulische weerstand is de c-waarde overgenomen uit het regionale grondwatermodel MORIA. Met deze weerstand wordt de kwel (of wegzijging) vanuit het watervoerend pakket naar het bodemprofiel berekend. Tevens is deze weerstand gebruikt om de wegzijging vanuit de waterlopen naar het watervoerende pakket te berekenen.

De uit metingen afgeleide uitgaande debieten die HHSK heeft aangeleverd, zijn benut om de modellering te kalibreren. Met name is hierbij gedetailleerd gekeken naar de boven- en onderrandvoorwaarden van de rekenplots. De kalibratie is zodanig uitgevoerd dat de berekende langjarige gemiddelde uitlaat overeenkomt met de uit metingen afgeleide uitlaat en dat daarbij ook het seizoenpatroon van netto-inlaat- en netto-uitlaatwater in overeenstemming is met de door HHSK geleverde debieten. De wegzijging over de deklaag naar het watervoerende pakket is in het intrekgebied rond de drinkwaterwinning van Oasen in de Krimpenerwaard afgestemd met wat voor die oeverwinning bekend is over de herkomst van het gewonnen water (aandeel Lekwater, infiltratie in de uiterwaarden en infiltrerend neerslagwater in de Krimpenerwaard). 


\section{Modelresultaten}

\subsection{Waterbalans}

De uit metingen afgeleide uitgaande debieten die HHSK heeft aangeleverd, zijn benut om de modellering van de rekenplots te kalibreren. Als uitgangspunt voor de kalibratie is aangehouden dat de langjarige gemiddelde netto-uitlaat (uitlaat minus inlaat) zoals het model berekent, overeenkomt met de uit metingen afgeleide netto-uitlaat. Hierbij zijn aanpassingen gedaan voor de weerstand van de kleilaag en drainageweerstanden. In het gebied rond de drinkwaterwinning van Oasen (deelgebied Krimpenerwaard) is ook gekeken naar de herkomst van de drinkwaterwinning (het aandeel afkomstig uit de Lek en het aandeel afkomstig van het intrekgebied in de Krimpenerwaard).

Met SWAP is voor iedere rekenplot de afstroming en drainage/infiltratie naar het oppervlaktewater berekend. Voor het oppervlaktewatersysteem zijn de neerslag en verdamping (open water) berekend en de kwel/wegzijging naar het watervoerende pakket. De optelsom hiervan is het netto-debiet, wat gelijk gesteld kan worden aan de uitlaat minus de inlaat. De aldus berekende netto-debieten zijn per deelgebied voor de zomers en winters weergegeven in Bijlage 3. In de figuur zijn ook de nettodebieten weergegeven die zijn afgeleid uit de gegevens van HHSK (uitlaat minus inlaat).

Uit de figuren van Bijlage 3 blijkt dat de modelberekeningen qua seizoenpatroon (zomer-winter) goed aansluiten bij de debietgegevens van HHSK. De correlatie tussen de gemodelleerde netto-debieten en de netto-debieten die zijn afgeleid van de debietgegevens van HHSK, is weergegeven in Figuur 4.1. Hieruit kan geconcludeerd worden dat de met het model berekende waterbalans goed overeenkomt met de debieten van de in- en uitlaat zoals die door het waterschap zijn afgeleid op basis van de meetgegevens.

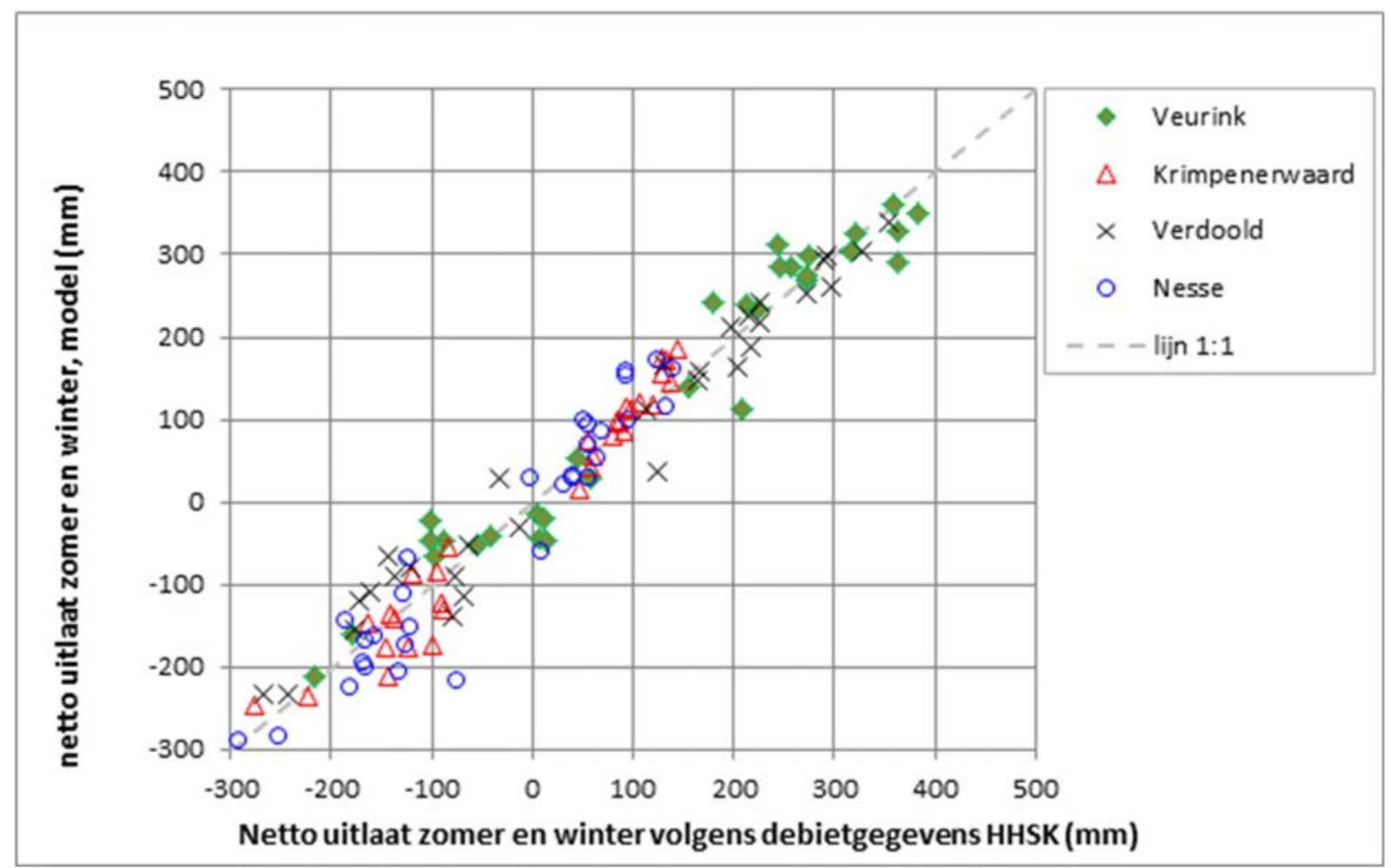

Figuur 4.1 Vergelijking netto-debiet berekend met het model en volgens de debietgegevens van HHNK 
De berekende balanstermen zijn weergegeven in Figuur 4.2. In deze figuur is de uitlaat minus de inlaat (netto-debiet) de optelsom van de overige balanstermen. Uit Figuur 4.2 kan worden afgelezen dat in de deelgebieden Krimpenerwaard en Nesse relatief veel oppervlaktewater wegzijgt naar het diepe grondwater en ook relatief veel oppervlaktewater infiltreert in het veenpakket. De resultaten van de kalibratie en daaruit volgende waterbalanstermen vormen een belangrijke basis voor de modellering van de af- en uitspoeling van nutriënten en de op te stellen nutriëntenbalansen.

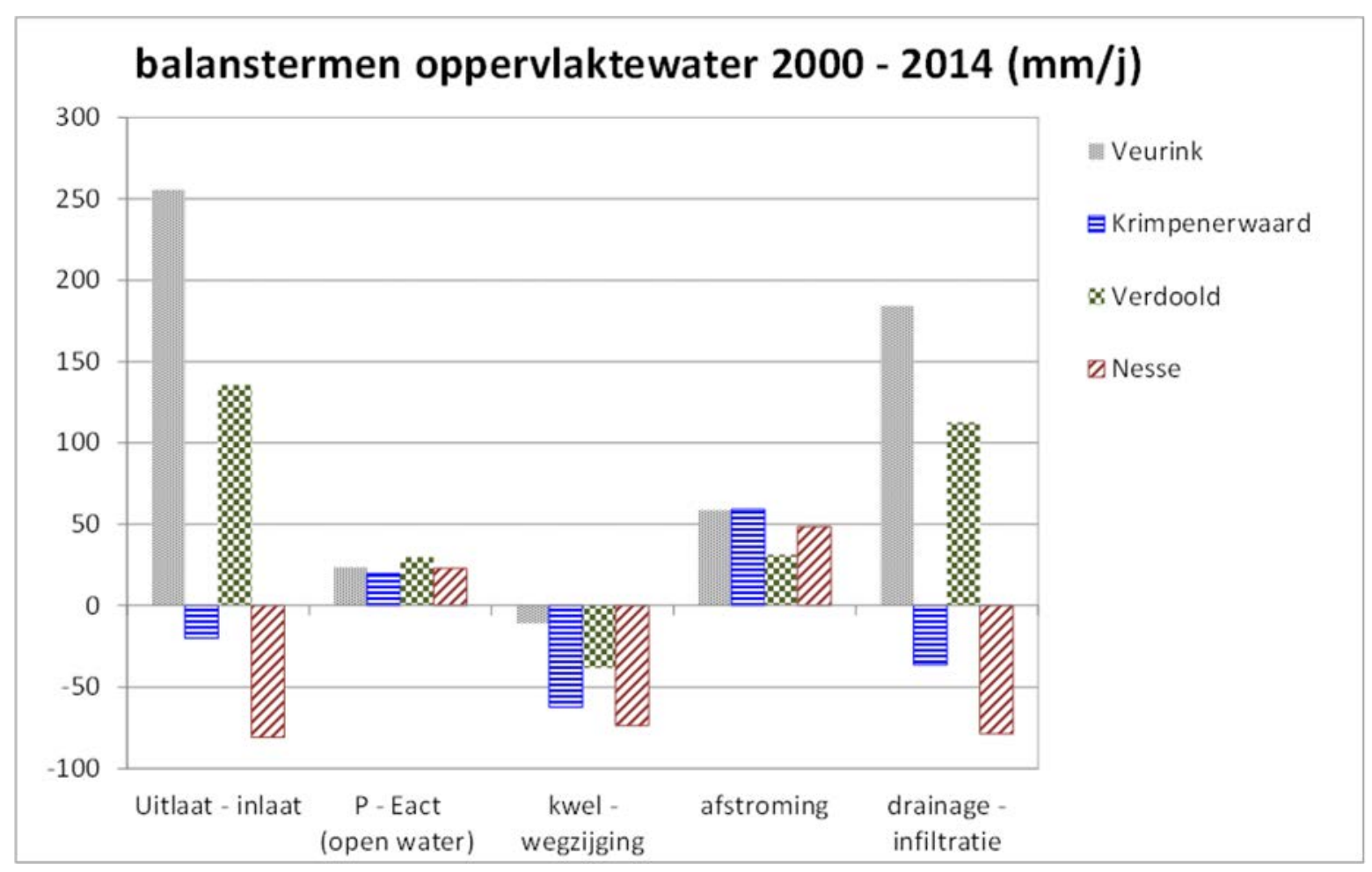

Figuur 4.2 Waterbalanstermen (langjarige gemiddelden)

\subsection{Uit- en afspoeling}

De berekende uit- en afspoeling is voor de vier gebieden weergegeven in Bijlage 4 (Figuur B4.1 en B4.2). Deze is ten behoeve van de interpretatie uitgesplitst in de bruto en netto af- en uitsplitsing. De nettobelasting door uit- en afspoeling is lager, omdat vooral in de zomer water met de daarin opgeloste nutriënten vanuit de sloten wegzijgt (infiltreert) naar het bodemprofiel. Dit geldt vooral in deelgebied Nesse en Krimpenerwaard en daarbij vooral voor fosfor, omdat het diepere transport bij fosfor groter is dan bij stikstof. De netto uit- en afspoeling (bruto uit- en afspoeling minus infiltratie) is het grootst in de deelgebieden Veurink en Verdoold.

De belasting van het oppervlaktewater met nutriënten varieert sterk over het jaar. Om deze variatie zichtbaar te maken, zijn over de gehele rekenperiode de gemiddelde maandvrachten berekend. Deze zijn weergegeven in Bijlage 4, Figuur B4.3 en Figuur B4.4. Uit deze analyse blijkt dat de uit- en afspoeling vooral plaatsvindt vanaf oktober tot en met maart en dat in de navolgende maanden (het groeiseizoen) de af- en uitspoeling veel lager is, vooral van april tot juli. In die maanden infiltreert ook een significant deel van de in het oppervlaktewater aanwezige stikstof en fosfor in het bodemprofiel. Dit is ook te verwachten, omdat dan de oppervlaktewaterpeilen relatief hoog zijn ten opzichte van de grondwaterstanden. 


\subsection{Overige emissies}

Vanuit de EmissieRegistratie zijn per deelgebied voor ieder jaar de overige punt- en diffuse bronnen berekend: overige landbouwemissies (glastuinbouw, meemesten, erafspoeling), rwzi's, atmosferische depositie op open water, industriële lozingen en overige diffuse bronnen (riooloverstorten, verkeer e.a.). De jaarvrachten van deze bronnen, gemiddeld over de periode 2000-2014, zijn voor stikstof en fosfor weergegeven in Tabel 4.1. Over deze periode bezien zijn de jaarvrachten van de rwzi's toegenomen (in 2008-2014 ongeveer een kwart hoger dan daaraan voorafgaand), de atmosferische depositie van stikstof is juist afgenomen (15\% t.o.v. 2000). De rwzi's vormen in de twee gebieden waarop wordt geloosd een significante bron, atmosferische depositie (direct op open water) is door het relatief grote areaal open water voor alle vier deelgebieden een significante diffuse bron. Zoals aangegeven in hoofdstuk 3, wordt voor atmosferische depositie in EmissieRegistratie met te kleine arealen open water gerekend (ca. 7\%). Daarom zijn deze getallen naar rato van de in deze studie aangenomen arealen open water naar boven bijgesteld.

Tabel 4.1

Overige punt- en diffuse stikstof- en fosforbronnen; gemiddelde jaarvrachten in de periode 2000-2014 (ton/jr.)

\begin{tabular}{|c|c|c|c|c|c|c|}
\hline Deelgebied & $\begin{array}{l}\text { Overige } \\
\text { landbouwemissies }{ }^{1)}\end{array}$ & Rwzi's & $\begin{array}{l}\text { Atmosferische depositie } \\
\text { open water }\end{array}$ & Stedelijk 2) & Overig ${ }^{3)}$ & Totaal \\
\hline \multicolumn{7}{|l|}{ stikstof } \\
\hline Veurink & 3,1 & - & 14,8 & 7,0 & 1,8 & 26,7 \\
\hline Krimpenerwaard & 2,5 & 4,6 & 10,9 & 2,7 & 1,1 & 21,7 \\
\hline \multicolumn{7}{|l|}{ fosfor } \\
\hline Nesse & 0,05 & - & - & 0,04 & 0,003 & 0,09 \\
\hline Veurink & 0,47 & - & - & 1,2 & 0,25 & 1,9 \\
\hline Krimpenerwaard & 0,37 & 1,38 & - & 0,45 & 0,11 & 2,3 \\
\hline
\end{tabular}

1) O.a. meemesten sloten, glastuinbouw, erafspoeling (Emissieregistratie 2013)

2) Stedelijk gebied: uit- en afspoeling, eenden, honden en bladval

3) Industriële lozingen en overige bronnen (o.a. overstorten, verkeer, vervoer) uit de Emissieregistratie 2013

\subsection{Nutriëntenbalans}

Met de resultaten van de modellering van de af- en uitspoeling en de kwantificering van de overige bronnen, retentie en inlaat, is voor ieder deelgebied een stikstof- en fosforbalans opgesteld. De jaarlijks berekende vrachten zijn opgenomen in de tabellen van Bijlage 5 . In Tabel 4.2 is voor ieder deelgebied de over de periode genomen gemiddelde belasting weergegeven, uitgedrukt in $\mathrm{kg} \mathrm{ha}^{-1}$. De absolute vrachten zijn opgenomen in Tabel 4.3 (ton jaar ${ }^{-1}$ ). Het aandeel van de verschillende bronnen wordt weergegeven in Figuur 4.3.

\section{Toetsing}

In hoeverre de berekende stikstof- en fosforbelasting van het oppervlaktewater per deelgebied plausibel is, kan worden getoetst door deze te vergelijken met de uit metingen en debietgegevens van HHSK afgeleide stikstof- en fosforvrachten. In Figuur 4.4 is de nettobelasting (ingaande minus uitgaande vrachten) vergeleken met wat uit de data (debieten in- en uitlaat, metingen en aannames van bijbehorende concentraties) van HHSK is afgeleid.

Vanwege de onzekerheden over de vrachten die op basis van de data van HHSK zijn afgeleid, is voor de vergelijking een bandbreedte (onzekerheidsmarge) aangehouden van $25 \%$. 
Tabel 4.2

Stikstof- en fosforbalans in $\mathrm{kg} \mathrm{ha}^{-1}$, gemiddeld over de periode $2000 \mathrm{t} / \mathrm{m} 2014$

\begin{tabular}{|c|c|c|c|c|c|c|c|c|}
\hline \multirow[t]{2}{*}{ Kop } & \multicolumn{4}{|c|}{ Stikstofbelasting } & \multicolumn{4}{|c|}{ Fosforbelasting } \\
\hline & Nesse & Veurink & Krimpenerwaard & Verdoold & Nesse & Veurink & Krimpenerwaard & Verdoold \\
\hline Uit- en afspoeling landbouw & 4,2 & 18,9 & 12,5 & 22,0 & $-0,22$ & 2,5 & 1,7 & 3,0 \\
\hline Overige landbouwemissies & 0,67 & 0,68 & 0,81 & 0,98 & 0,08 & 0,10 & 0,12 & 0,14 \\
\hline Atmosferische depositie & 3,3 & 3,3 & 3,5 & 4,3 & - & - & - & - \\
\hline Industriële lozingen & 0,002 & 0,03 & 0,000003 & 0,01 & 0,0003 & 0,01 & 0,000001 & 0,002 \\
\hline Overige bronnen & 0,08 & 0,38 & 0,34 & 0,25 & 0,004 & 0,05 & 0,03 & 0,04 \\
\hline Inlaat & 6,1 & 8,0 & 25,8 & 5,7 & 1,3 & 0,44 & 2,20 & 1,3 \\
\hline Directe kwel/wegzijging & $-2,8$ & $-0,32$ & $-1,4$ & $-1,5$ & $-0,73$ & $-0,09$ & $-0,20$ & $-0,19$ \\
\hline Retentie & 11,4 & 18,0 & 23,5 & 18,7 & 0,65 & 1,6 & 1,6 & 2,1 \\
\hline Totaal UIT (ECHO) & 8,6 & 17,6 & 22,1 & 17,2 & 0,74 & 1,9 & 3,0 & 2,9 \\
\hline Totaal UIT (data HHSK) & 5,5 & 18,7 & 22,3 & 15,4 & 1,14 & 3,9 & 3,6 & 2,1 \\
\hline
\end{tabular}

Tabel 4.3

Stikstof- en fosforbalans in ton jaar ${ }^{-1}$, gemiddeld over de periode 2000 t/m 2014

\begin{tabular}{|c|c|c|c|c|c|c|c|c|}
\hline \multirow[t]{2}{*}{ Kop } & \multicolumn{4}{|c|}{ Stikstofbelasting } & \multicolumn{4}{|c|}{ Fosforbelasting } \\
\hline & Nesse & Veurink & Krimpenerwaard & Verdoold & Nesse & Veurink & Krimpenerwaard & Verdoold \\
\hline Uit- en afspoeling landbouw & 2,3 & 85,7 & 39,0 & 115 & $-0,12$ & 11,2 & 5,3 & 15,8 \\
\hline Overige landbouwemissies & 0,37 & 3,1 & 2,5 & 5,1 & 0,05 & 0,47 & 0,37 & 0,73 \\
\hline Atmosferische depositie & 1,8 & 14,8 & 10,9 & 22,2 & - & - & - & - \\
\hline Industriële lozingen & 0,001 & 0,11 & 0,00001 & 0,04 & 0,0002 & 0,02 & 0,000002 & 0,01 \\
\hline Overige bronnen & 0,04 & 1,7 & 1,1 & 1,3 & 0,002 & 0,22 & 0,11 & 0,19 \\
\hline Inlaat & 3,4 & 36,5 & 80,6 & 29,8 & 0,71 & 2,0 & 6,8 & 7,0 \\
\hline Directe kwel/wegzijging & $-1,5$ & $-1,4$ & $-4,3$ & $-7,7$ & $-0,41$ & $-0,43$ & $-0,64$ & $-1,0$ \\
\hline Retentie & 6,3 & 82 & 73 & 98 & 0,36 & 7,5 & 4,9 & 10,8 \\
\hline Totaal UIT (ECHO) & 4,8 & 80 & 69 & 90 & 0,41 & 8,7 & 9,5 & 15,2 \\
\hline Totaal UIT (data HHSK) & 3,0 & 85 & 70 & 80 & 0,63 & 17,6 & 11,1 & 11,0 \\
\hline
\end{tabular}



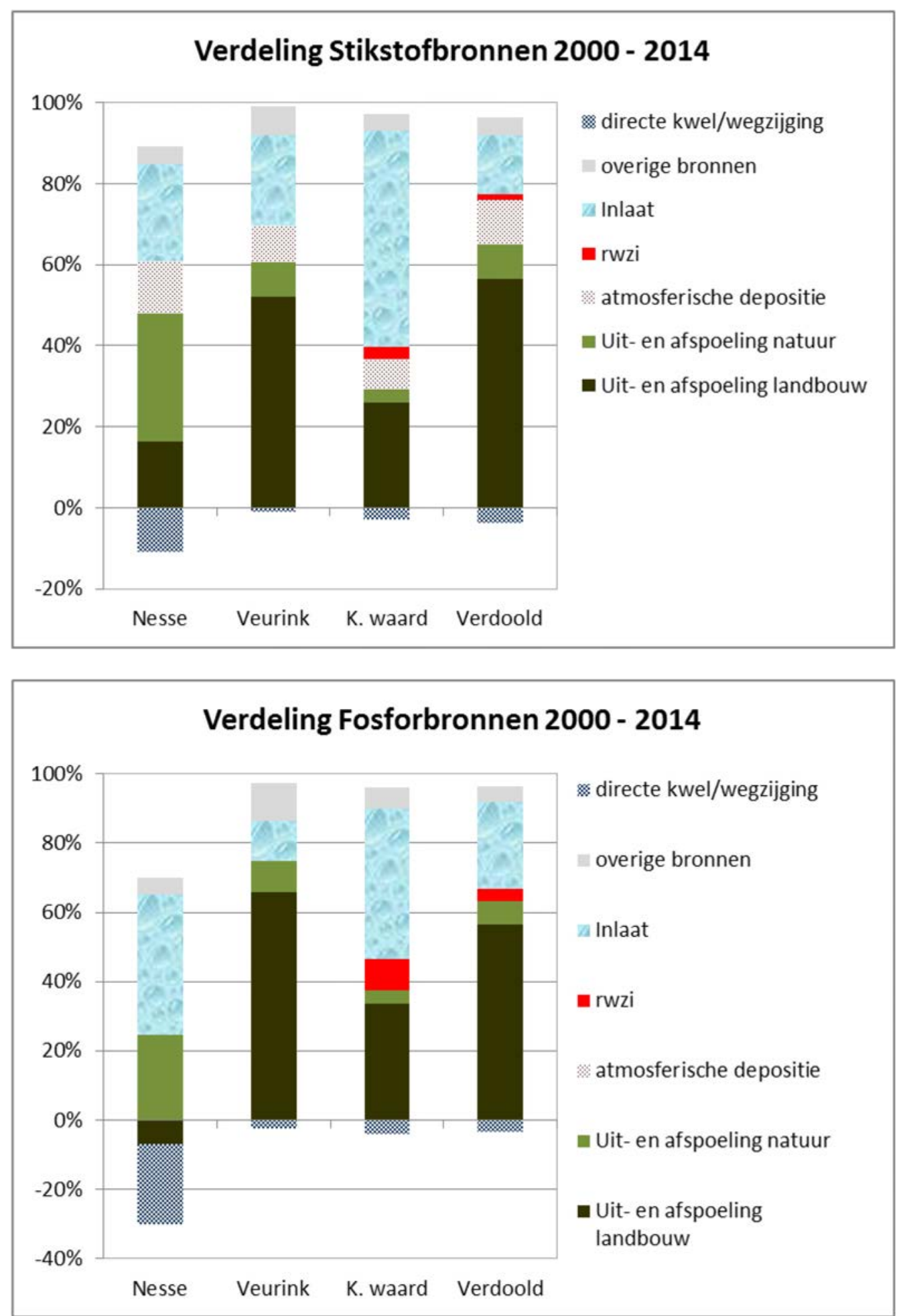

Figuur 4.3 Aandeel van de verschillende bronnen in de totale stikstofbelasting (boven) en fosforbelasting (onder). In de berekende percentages is retentie niet meegenomen 

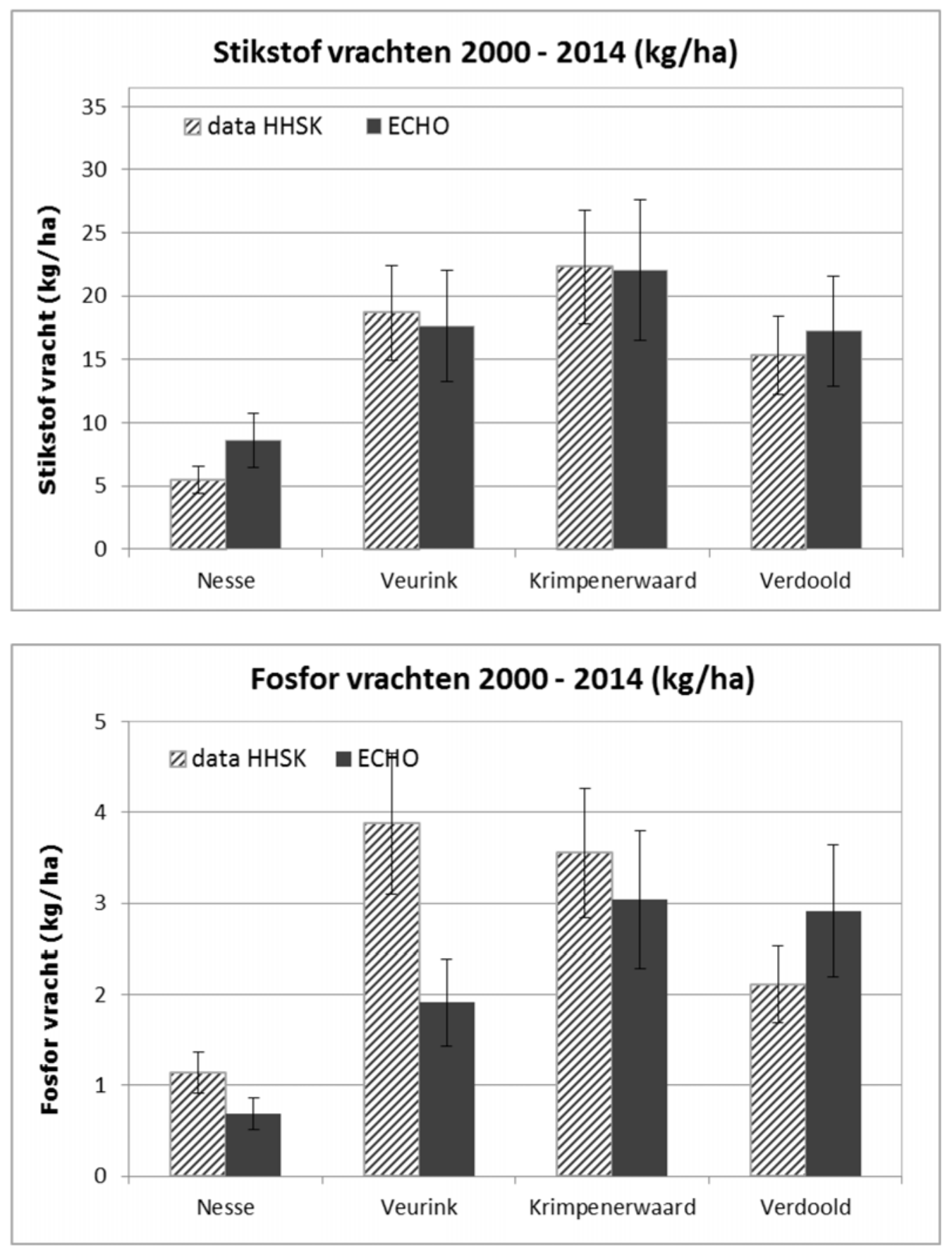

Figuur 4.4 Vergelijking uitgaande vrachten zoals berekend met ECHO en zoals afgeleid uit de data van HHSK (debieten en concentraties in- en uitlaat). In de figuur zijn indicatieve bandbreedtes voor onzekerheidsmarges aangegeven

Uit deze overzichten blijkt dat:

- De balansen redelijk goed overeenkomen met de nettovrachten (uitlaat minus inlaat) die zijn afgeleid uit de data (concentraties en debieten) van HHSK. De berekende en uit metingen afgeleide belasting komt voor de Krimpenerwaard en Verdoold vrij goed overeen. Voor deelgebied Veurink is de fosforbelasting duidelijk lager dan uit de metingen is afgeleid en voor de Nesse lijkt de stikstofbelasting iets te worden overschat.

- De belangrijkste posten in de stikstofbalans zijn af- en uitspoeling landbouwgronden, inlaat, atmosferische depositie en af- en uitspoeling vanuit natuurgronden. De belangrijkste posten in de fosforbalans zijn af- en uitspoeling landbouwgronden, inlaat en uit- en afspoeling natuur.

- Opvallend is dat directe wegzijgingsverliezen vanuit de waterlopen naar diep grondwater een belangrijke negatieve balansterm is in deelgebied Nesse, met name geldt dit voor fosfor. Ook in de Krimpenerwaard en Verdoold geeft de kwel/wegzijging een negatieve balans. 


\subsection{Herkomst analyse uit- en afspoeling}

Een belangrijk doel van de bronnenanalyse is om onderscheid te kunnen maken tussen bronnen die beïnvloedbaar zijn en direct effect sorteren, bronnen die ook beïnvloedbaar zijn, maar waar effecten pas op korte tot langere termijn zichtbaar worden en bronnen die niet of nauwelijks in het gebied (regionaal) beïnvloedbaar zijn. Deze indeling is weergegeven in Tabel 4.4.

\section{Tabel 4.4}

Stikstof- en fosforbalans in ton/jaar, gemiddeld over de periode 2000 t/m 2014

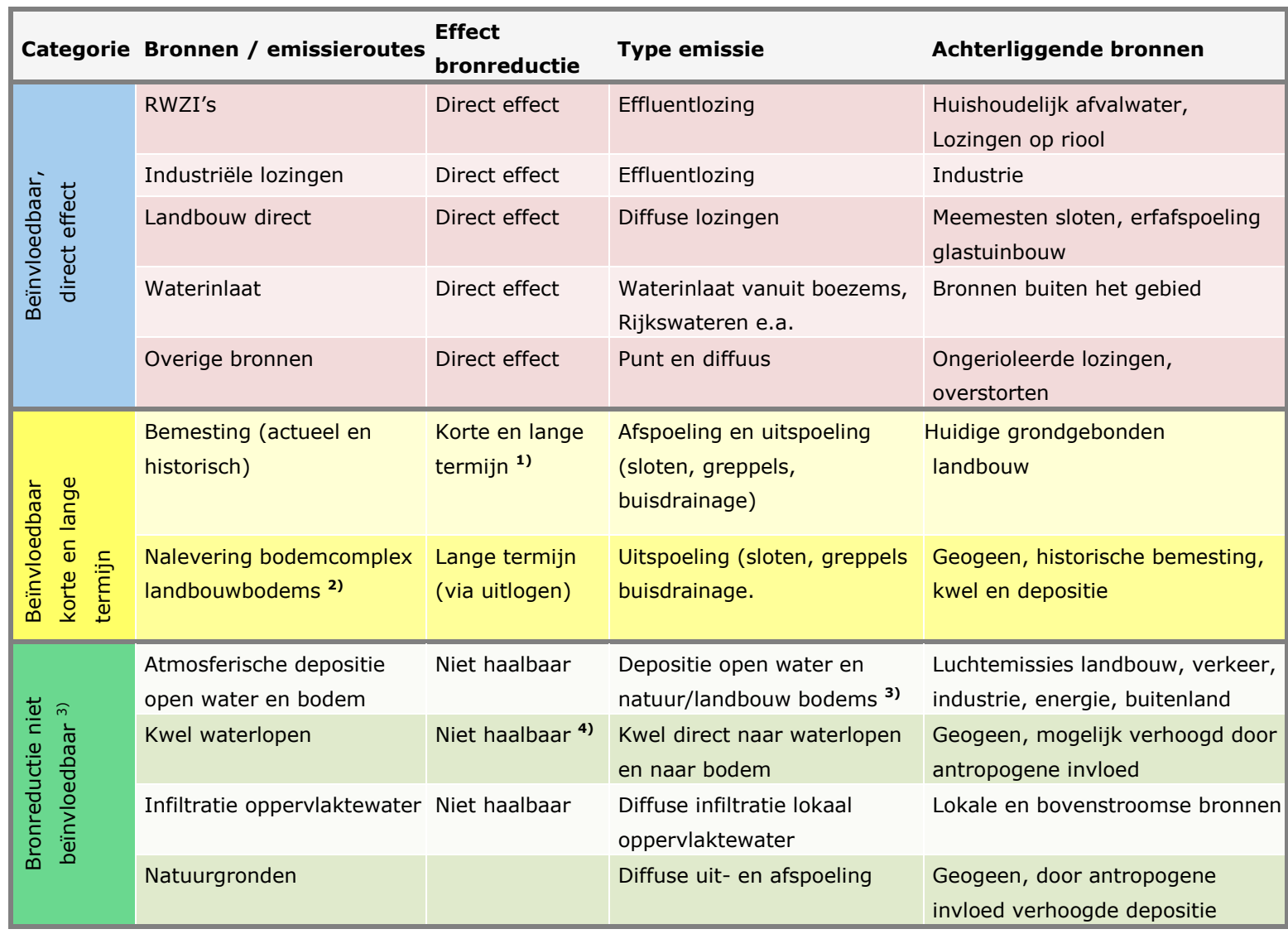

1) Kortetermijneffect voornamelijk de reductie van de routeafspoeling, hotspots, korte stromingspatronen. Zowel voor stikstof als fosfor zal bronreductie voor een deel snel effect hebben. Voor fosfor kan het uiteindelijke effect decennia lang duren, voor stikstof is deze termijn i.h.a. korter.

2) Nalevering door verwering, oplossen metaal(hydr)oxides, oxidatie, historische bemesting, historische kwel en historische depositie.

3) Bronreductie niet haalbaar, maar atmosferische depositie op landbouwbodems zou meegerekend kunnen worden in het bepalen van de mestgiften om te komen tot evenwichtsbemesting. In voorgenomen landelijk mestbeleid wordt atmosferische depositie niet meegerekend.

4) Significante bronreductie niet haalbaar, omdat de bron gerelateerd is aan de functie van het gebied c.q. de drooglegging en daardoor is op te vatten als onomkeerbare hydromorfologische ingreep.

Beleidsmatig kan deze indeling worden gebruikt om een achtergrondbelasting en daaruit af te leiden achtergrondconcentraties te bepalen, en daarmee het afleiden of bijstellen van KRW-doelen te ondersteunen. Bij dit onderscheid en deze terminologie moet worden bedacht dat de bronnen die gerekend worden tot de achtergrondbelasting voor een deel ook antropogeen beinvloed zijn. Atmosferische depostie van stikstof is verhoogd door invloed van verkeer, industrie en ammoniakemissie landbouw. En de nalevering vanuit het bodemcomplex (geogeen) is verhoogd, doordat de ontwatering van moerige bodems gepaard gaat met versnelde mineralisatie. 
Maar omwille van het stellen van realistische doelen wordt voor atmosferische depositie gesteld dat dit niet op het niveau van waterlichamen of beheergebieden van waterschappen significant teruggedrongen kan worden en dat nalevering vanuit het bodemcomplex niet zonder rigoreuze maatregelen teruggedrongen kan worden.

$\mathrm{Nu}$ is in het voorgaande al met ECHO de stikstof- en fosforbelasting van de verschillende bronnen berekend. Alleen is daarbij nog geen onderscheid gemaakt in de bronnen achter de af- en uitspoeling.

De te onderscheiden achterliggende bronnen achter de af- en uitspoeling zijn:

- atmosferische depositie;

- bemestingsoverschot (historisch en actueel);

- kwel;

- nalevering bodem (geogeen);

- uitspoeling van eerder gefiltreerd oppervlaktewater; als de grondwaterstanden lager zijn dan de slootpeilen, infiltreert dit slootwater in het bodemprofiel en spoelt dan later (als de grondwaterstanden weer hoger zijn dan het waterpeil in de sloot) weer uit.

Het aandeel van de af- en uitspoeling in de totale uitspoeling is weergegeven in Tabel 4.5. Uit Tabel 4.5 blijkt dat de af- en uitspoeling voor zowel stikstof als fosfor een groot aandeel heeft in de totale belasting, met name deelgebied Verdoold en Veurink (65 à 70\%). In de Nesse en Krimpenerwaard is dit aandeel voor fosfor beduidend lager, omdat er veel wegzijging plaatsvindt en daarmee de inlaat hier een relatief groot deel van de belasting vormt.

\section{Tabel 4.5}

Aandeel uit- en afspoeling ten opzichte van de totale belasting. Hierbij is de (negatieve) kwel/wegzijging niet meegerekend in de totale belasting

\begin{tabular}{lllllllll} 
& \multicolumn{2}{l}{$\begin{array}{l}\text { Stikstof uit- en afspoeling t.0.v. totale } \\
\text { belasting }\end{array}$} & & & \multicolumn{2}{c}{$\begin{array}{l}\text { Fosfor uit- en afspoeling t.0.v. totale } \\
\text { belasting }\end{array}$} \\
\cline { 2 - 9 } & Nesse & Veurink & Krimpenerwaard Verdoold Nesse & Veurink & Krimpenerwaard Verdoold \\
Landbouw percelen & $18 \%$ & $53 \%$ & $27 \%$ & $59 \%$ & $-11 \%$ & $67 \%$ & $35 \%$ & $5 \%$ \\
\hline Natuur percelen & $35 \%$ & $9 \%$ & $4 \%$ & $9 \%$ & $39 \%$ & $9 \%$ & $4 \%$ & $7 \%$ \\
\hline Landbouw \& natuur & $54 \%$ & $61 \%$ & $30 \%$ & $67 \%$ & $28 \%$ & $77 \%$ & $39 \%$ & $65 \%$ \\
\hline
\end{tabular}

Het is niet eenvoudig om de precieze herkomst en daarmee de bijdrage van bronnen achter uit- en afspoeling te kwantificeren, omdat de verschillende emissiebronnen op verschillende plaatsen in het plant-bodem-watersysteem aangrijpen en verschillende emissieroutes andere omzettings- en vastlegginsprocessen volgen. Omdat de bronsterkte (bemesting, depositie, kwel) invloed heeft op de omzettingsprocessen in de bodem en de gewasopname en deze processen elkaar ook onderling beïnvloeden, kan de bijdrage van de afzonderlijke bronnen niet met eenvoudige aan-uit modelscenario's worden berekend. Alterra heeft daarom een nieuwe rekenmethode ontwikkeld, waarbij de bronsterkte in elke nieuwe rekenrun steeds een klein stapje wordt verminderd. Uit de resultaten van deze rekenruns wordt vervolgens een regressie berekend tussen de bronsterkte en de resulterende uit- en afspoeling.

Deze methode is toegepast en nader toegelicht in de achtergrondrapportage Bronnen van diffuse nutriëntenbelasting van het oppervlaktewater. Evaluatie Meststoffenwet 2012 (Groenendijk et al., 2012). De herkomst van de bronnen kan met deze methode worden berekend voor STONE-rekenplots. Dit is landsdekkend gedaan voor de evaluatie van de Mestwetgeving in 2014 (Groenendijk et al., 2014). In de onderhavige studie zijn echter specifieke rekenplots gegenereerd die op onderdelen afwijken van STONE-plots. Daarom is voor de onderverdeling in achterliggende bronnen uitgegaan van resultaten van de studie Monitoring Stroomgebieden. Wel is deze onderverdeling vergeleken met de gedane bronnenanalyse van STONE-plots in veenweidegebieden (STONE-plots in veenweidegebied. Landbouwgrasland, grondwatertrappen II-III*). De procentuele bijdrage van de bronnen achter de uiten afspoeling die voor Monitoring Stroomgebieden is berekend, is redelijk in overeenstemming met wat voor de STONE-plots is berekend. 
Figuur 4.5 laat de te onderscheiden achterliggende bronnen van de uit- en afspoeling zien. De grootste bronnen zijn de bemesting en de veenbodem. Bij de laatste gaat het om mineralisatie (vooral stikstof) en uitloging van de permanent verzadigde veenbodem. Bemesting is onderverdeeld in 'huidig', toegediend in de periode 2001 t/m 2010, en 'historisch', toegediend in de periode $1941 \mathrm{t} / \mathrm{m}$ 2000.

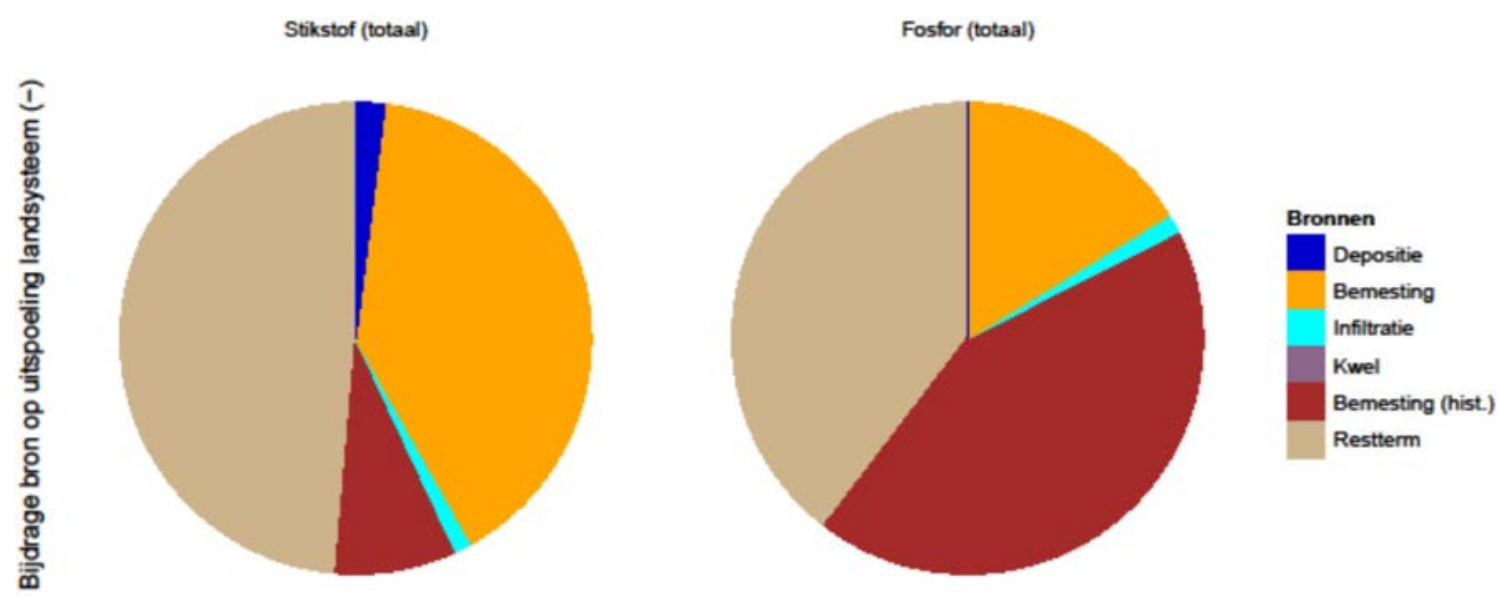

Figuur 4.5 Verdeling van de bronnen achter de uit- en afspoeling

Voor stikstof is de bijdrage van bemesting en de veenbodem even groot: $48 \%$. 38 procentpunten (80\%) hiervan komen voor rekening van de huidige bemesting en de overige 10 procentpunten van historische bemesting. Met mest toegediende stikstof wordt voor een deel ingebouwd in de organische stof van humus en verrijkt op die manier de bodem met $\mathrm{N}$. Aan het bodemcomplex geboden $\mathrm{N}$ is een relatief maar zeer kleine hoeveelheid. Van de overige bronnen speelt alleen de atmosferische depositie nog een kleine rol (ca. 4\%).

Voor fosfor is de bijdrage van de bemesting met bijna $60 \%$ anderhalf keer zo groot als die van de bodem (40\%). Opvallend daarbij is dat de historische bemesting het grootste aandeel levert: 42 procentpunten (70\%) tegen bijna 18 procentpunten voor de recente bemesting. De historische bemesting bestaat uit aan het bodemcomplex gebonden fosfaat die afkomstig is van vanaf 1941 toegediende fosformeststoffen. Bij P heeft alleen de infiltratie van oppervlaktewater nog een zeer geringe bijdrage aan de belasting van datzelfde oppervlaktewater. Het kan hierbij deels om dezelfde fosfor gaan die eerder is uitgespoeld.

De onderverdeling in wel/niet beïnvloedbare bronnen is weergegeven in Tabel 4.6. Met deze onderverdeling kunnen keuzes voor het afleiden van achtergrondconcentraties, het eventueel bijstellen van waterkwaliteitsdoelen en inzet voor maatregelen worden onderbouwd. 
Tabel 4.6

Aandeel nutriëntenbronnen naar de mate waarin deze beïnvloed kunnen worden (naar indeling Tabel 4.4)

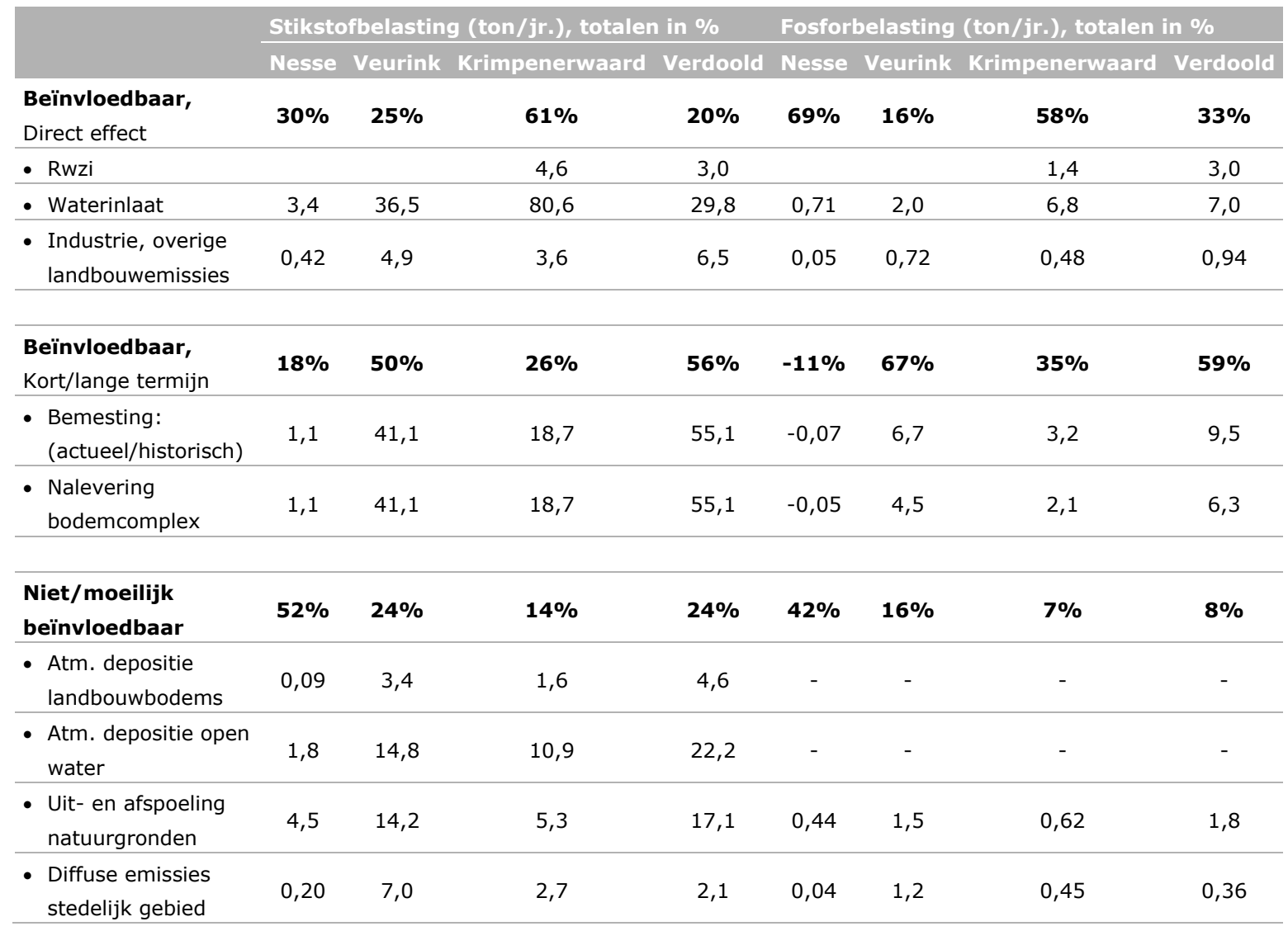




\section{Scenario's}

\section{$5.1 \quad$ Inleiding}

Met ECHO zijn berekeningen uitgevoerd om de effecten te verkennen van de volgende scenario's:

- Autonome situatie

- Kringlooplandbouw

- Uitbreiding areaal natuur

- Onderwaterdrainage

Tabel 5.1 geeft een overzicht van de uitgangspunten die voor deze scenario's zijn aangehouden. De uitgangspunten die in de berekeningen veranderen, betreft de input van de SWAP-Animo rekenplots waarmee de uit- en afspoeling wordt berekend. Dit betreft input voor de meteo (neerslag en verdamping), de mestgiften en de drooglegging in de natuur en landbouwgronden.

Tabel 5.1

Uitgangspunten rekenscenario's voor de berekening van de uit- en afspoeling

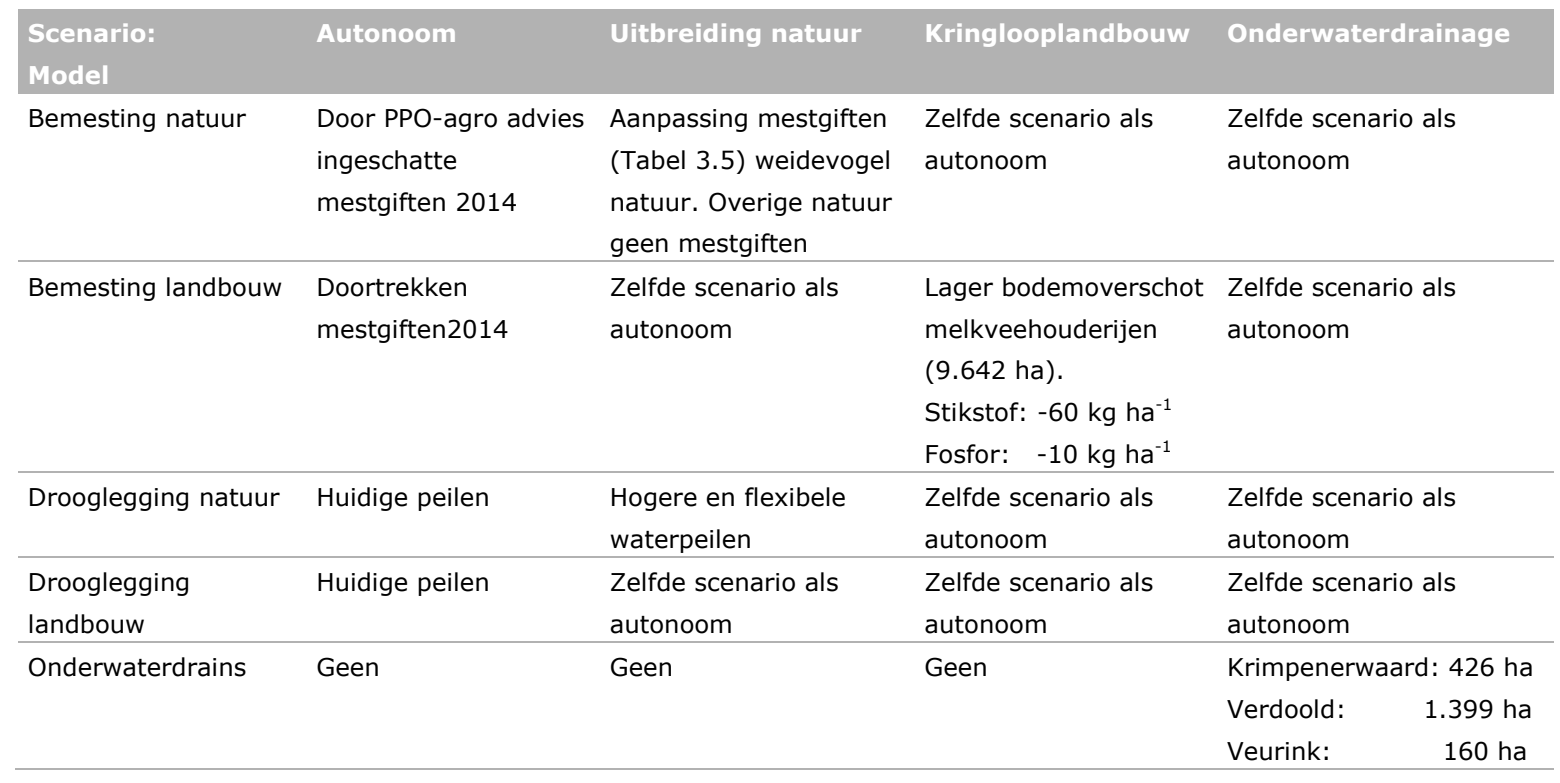

\subsection{Uitgangspunten scenario's}

\section{Algemeen}

Voor alle rekenscenario's geldt dat met het modelinstrumentarium een periode van 15 jaar is doorgerekend. De eindsituatie van de berekende huidige situatie (eind december 2014) is voor elk scenario het beginpunt van de modelberekeningen. In principe wordt dus de periode 2015 tot 2029 doorgerekend met de meteo van 2000-2014. Om de invloed van het klimaat eruit te filteren, worden de scenario's met elkaar vergeleken op basis van de 15-jaar gemiddelde uit- en afspoeling. Het tijdvenster waarop de verschillen tussen de scenario's worden beschouwd, is daarmee 7,5 jaar. 


\section{Autonome situatie}

Om de effecten van scenario's te kunnen berekenen, is een autonome situatie berekend door vanaf 2014 een klimaatperiode van eveneens 15 jaar door te rekenen met het huidige landgebruik, drooglegging en hetzelfde klimaat als 2000-2014. Hierbij is de bemestingsdruk van 2014 doorgetrokken.

Kringlooplandbouw (verlaging van de bodemoverschotten in de landbouwpercelen)

Bij melkveehouderijen kan door een uitgekiend pakket van maatregelen de efficiency van het mineralenmanagement verbeteren, zodanig dat de verliezen naar de bodem afnemen zonder dat het bedrijfsresultaat afneemt. Met de adviestool KringloopWijzer kunnen bij een bedrijf de verbeterpunten voor het mineralenmanagement worden geïdentificeerd. In de Voorstudie Kringlooplandbouw veenweide (Schipper et al., 2015), is op basis van beschikbare KringloopWijzer data geconcludeerd dat voor stikstof het bodemoverschot in het veenweidegebied kan afnemen met grofweg $60 \mathrm{~kg} \mathrm{~N} \mathrm{ha}^{-1}$, voor fosfor met $11 \mathrm{~kg} \mathrm{P} \mathrm{ha}^{-1}$.

\section{Uitbreiding areaal natuur}

Het hoogheemraadschap heeft een kaart geleverd met daarin weergegeven de EHS-gebieden. Deze kaart is geclipt en omgezet in een rasterbestand (zie Figuur 5.1). In de berekening van de huidige situatie is hiervan ongeveer de helft natuur, aangenomen is dat deze volgens weidevogelbeheer worden bemest. In het scenario verdubbelt het areaal natuur ongeveer. De voor het scenario gehanteerde natuurarealen zijn weergegeven in Tabel 5.2.

Tabel 5.2

Arealen natuur en verdeling tussen weidevogelbeheer en overig natuurgrasland

\begin{tabular}{|c|c|c|c|c|c|c|}
\hline & Nesse & & Veurink & Krimpenerwaard & Verdoold & Totaal \\
\hline Natuur areaal Huidig & 173 & & 222 & 164 & 560 & 1.119 \\
\hline Natuur areaal toekomst scenario & 300 & & 400 & 170 & 1.170 & 2.040 \\
\hline Overig & & 0 & & 0 & 570 & 970 \\
\hline
\end{tabular}

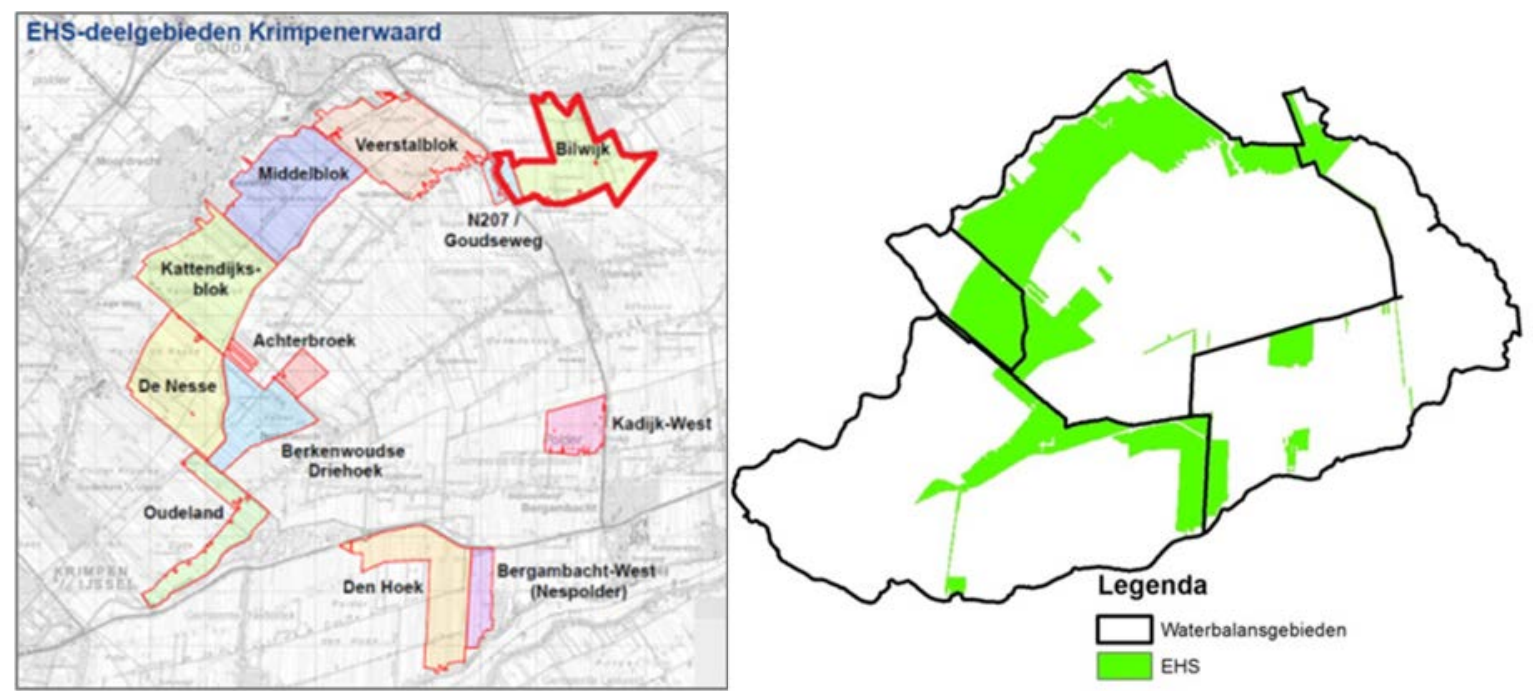

Figuur 5.1 Areaal EHS binnen de deelgebieden van de Krimpenerwaard 
Voor al deze gebieden is ook aangenomen dat de oppervlaktewaterpeilen iets worden verhoogd, uitgaande van flexibel peilbeheer. De huidige en de voor het scenario aangenomen flexibele peilen zijn weergeven in Tabel 5.3 en Figuur 5.2. Voor het flexibele peilbeheer wordt in het model de waterbalans volgens een bakjessysteem bijgehouden. Bij een peildaling van 7,5 cm wordt in het model dan water aangevoerd, en bij een peilstijging van 7,5 wordt water afgevoerd. De drooglegging is bepaald uit het verschil tussen de maaiveldhoogte volgens de AHN3 en de peilen volgens Figuur 5.2. Het resultaat staat in Figuur 5.3. De gebieden Graafzijde-Zuid en Achterbroek-West laten een zeer geringe drooglegging zien. Per basisplot (Swap-Animo) is de gemiddelde drooglegging van de bijbehorende grids met natuur en de bijbehorende oppervlakte bepaald. Vervolgens zijn de plots geclusterd naar rekenplots waarbij de gemiddelde drooglegging is bepaald, gewogen naar oppervlakte van de bijbehorende plots.

\section{Tabel 5.3}

Overzicht peilgebieden bemalingsgebied Verdoold

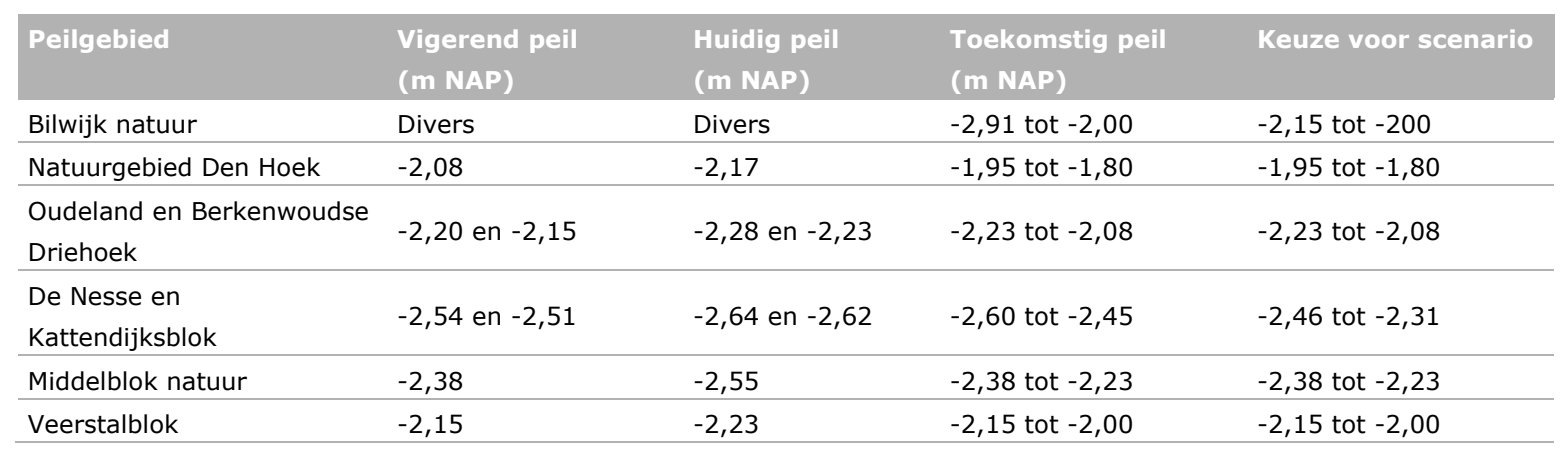

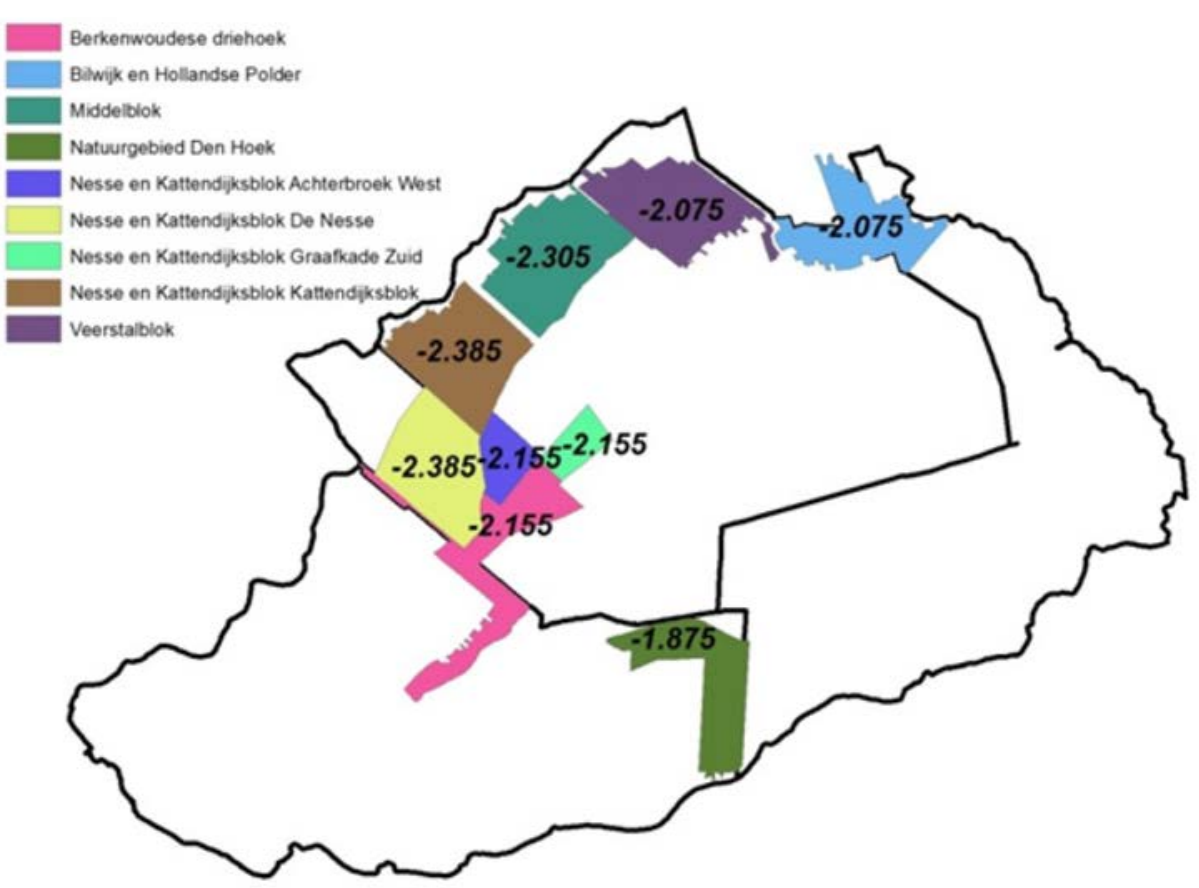

Figuur 5.2 Aangenomen gemiddelde waterpeil toekomstige natuur 


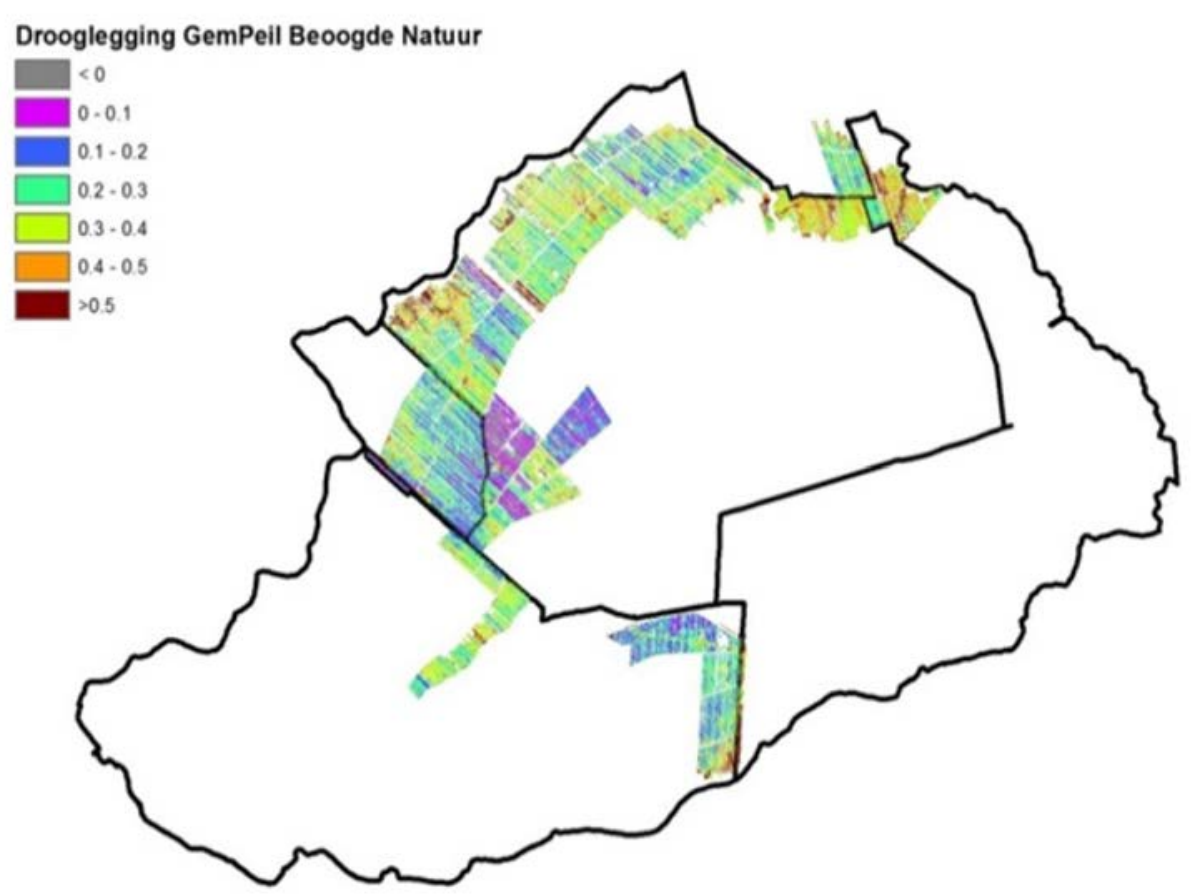

Figuur 5.3 Drooglegging voor toekomstige natuur

\section{Onderwaterdrainage}

Onderwaterdrainage kan in veengebieden de oxidatie van het veen en daarmee de maaivelddaling vertragen en daarbij ook een positieve invloed hebben op de uitspoeling van nutriënten. Voor het scenario is aangenomen dat $20 \%$ van de landbouwpercelen wordt uitgerust met onderwaterdrainage.

Voor de keuze van de gebieden waar deze in potentie aanwezig is, is aangehouden dat onderwaterdrainage wordt toegepast op de koopveengronden waar de drooglegging in de huidige situatie varieert van 40 tot $60 \mathrm{~cm}-\mathrm{mv}$. Met deze criteria komen hoofdzakelijk landbouwpercelen in Verdoold in aanmerking. Voor de hier geselecteerde rekenplots is de drooglegging ongeveer $45 \mathrm{~cm}-\mathrm{mv}$. Ook een aantal rekenplots in de Krimpenerwaard en Veurink komen hiervoor in aanmerking.

\subsection{Berekende effecten autonome situatie}

De rekenresultaten van de autonome situatie zijn weergegeven in Figuur 5.4. In de figuur worden de vijftienjarig gemiddelde vrachten vergeleken met de gemiddelde uit- en afspoeling zoals die is berekend voor de huidige situatie. In principe gelden de gemiddeldes van het autonome scenario voor de periode 2015 tot en met 2029. Zoals eerder aangegeven, is hierbij dezelfde meteo aangehouden als 2000-2014. Klimaateffecten worden aldus niet meegenomen. De berekende absolute vrachten zijn op jaarbasis weergegeven in Bijlage 5. Ten opzichte van de huidige situatie wordt voor de autonome situatie een lagere uit- en afspoeling voor stikstof berekend, omdat enerzijds lagere mestgiften dan in de huidige situatie zijn ingevoerd (zie Tabel 3.3) en anderzijds omdat er minder naijlingeffect is van de hoge mestgiften in de periode vóór 2000. De fosforbelasting van het oppervlaktewater neemt echter toe (m.u.v. Verdoold). 

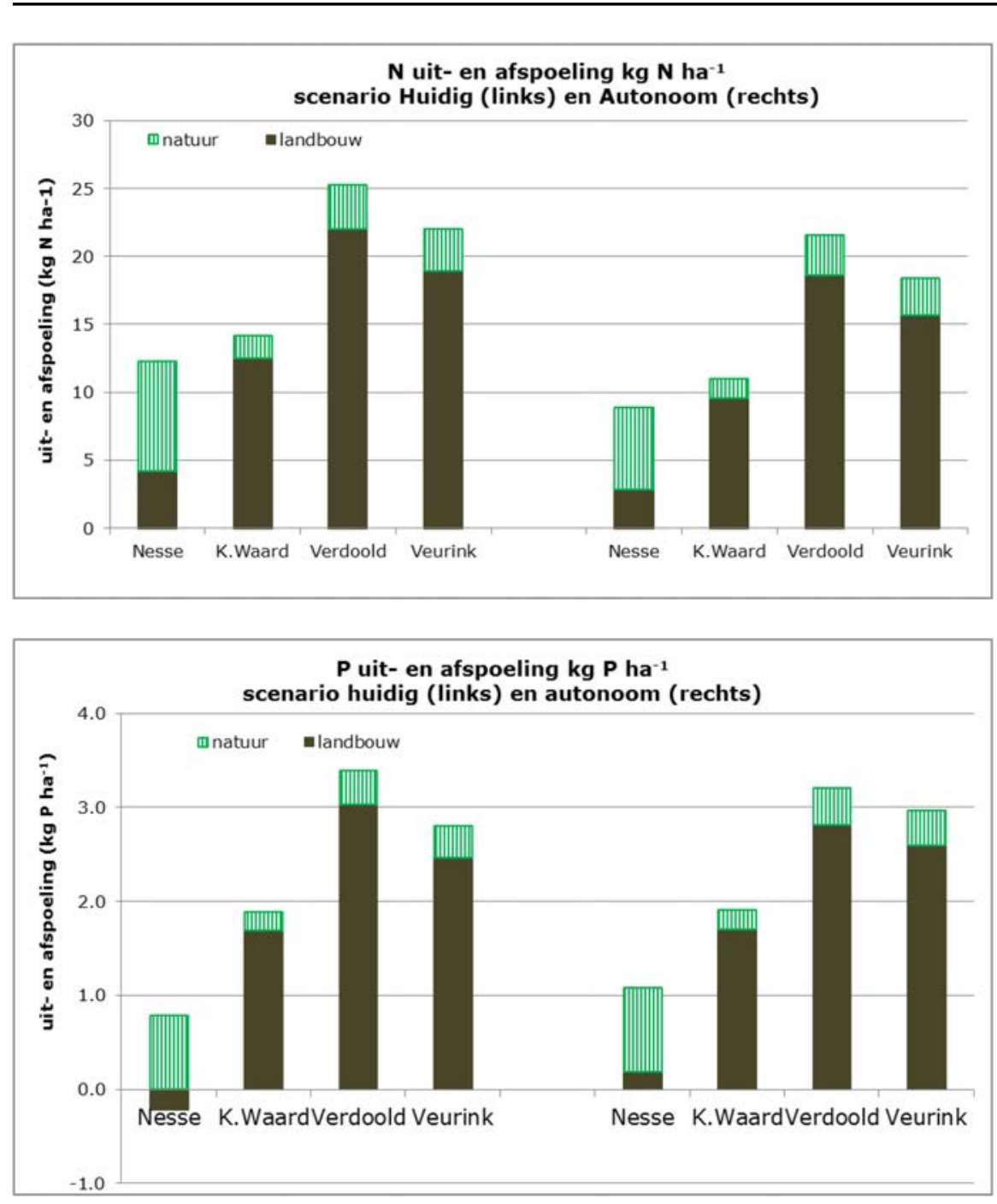

Figuur 5.4 Berekende uit- en afspoeling autonome situatie, vergeleken met de huidige situatie 


\subsection{Berekende effecten scenario's}

De scenario's voor de uitbreiding van natuur, onderwaterdrainage, kringlooplandbouw en een combinatie daarvan hebben effect op de uit- en afspoeling van de nutriënten naar het oppervlaktewater. In Figuur 5.5 zijn deze effecten weergegeven voor de huidige situatie en de berekende scenario's. De berekende absolute waarden voor de af- en uitspoeling zijn opgenomen in Tabel 5.4. De verschillen ten opzichte van de autonome situatie zijn opgenomen in Tabel 5.5.
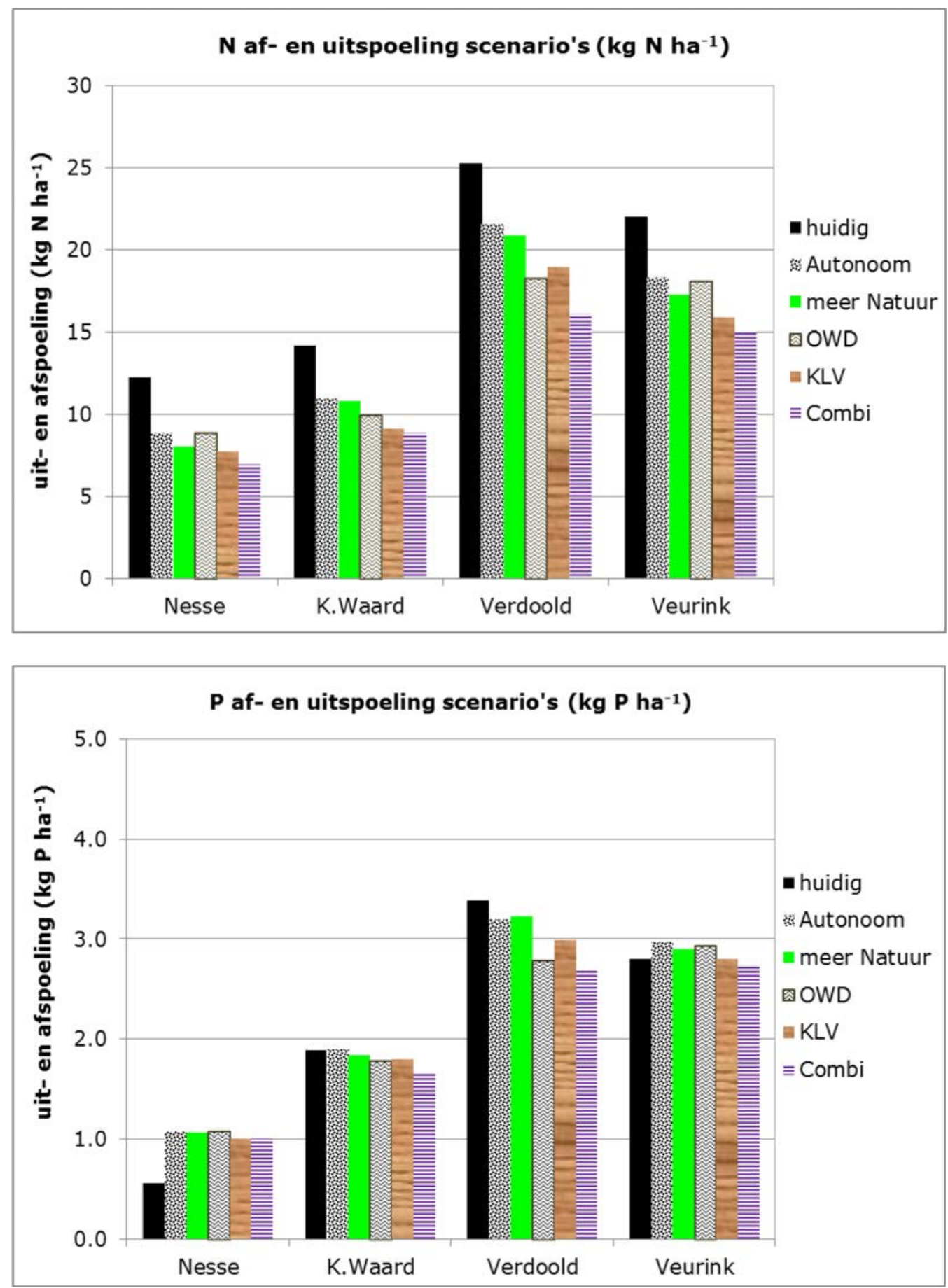

Figuur 5.5 Berekende uit- en afspoeling scenario's 
Tabel 5.4

Berekende uit- en afspoeling huidige situatie en de vijf scenario's. Onderwaterdrainage is afgekort als OWD, Kringlooplandbouw veenweide als KLV, Combi betreft meer natuur+ OWD + KLV

\begin{tabular}{|c|c|c|c|c|c|c|c|}
\hline Deelgebied & Areaal (ha) & Huidig & Autonoom & Meer Natuur & OWD & KLV & Combi \\
\hline \multicolumn{8}{|c|}{ Totale uit- en afspoeling stikstof $\left(\mathrm{kg} \mathrm{N} \mathrm{ha}^{-1} \mathrm{jaar}^{-1}\right)$} \\
\hline Nesse & 553 & 12,3 & 8,9 & 8,0 & 8,9 & 7,8 & 6,9 \\
\hline Verdoold & 5.219 & 25,3 & 21,6 & 20,9 & 18,2 & 19,0 & 16,1 \\
\hline Veurink & 4.539 & 22,0 & 18,3 & 17,3 & 18,1 & 15,9 & 15,0 \\
\hline Nesse & 553 & 0,6 & 1,1 & 1,1 & 1,1 & 1,0 & 1,0 \\
\hline Krimpenerwaard & 3.125 & 1,9 & 1,9 & 1,8 & 1,8 & 1,8 & 1,7 \\
\hline Verdoold & 5.219 & 3,4 & 3,2 & 3,2 & 2,8 & 3,0 & 2,7 \\
\hline Veurink & 4.539 & 2,8 & 3,0 & 2,9 & 2,9 & 2,8 & 2,7 \\
\hline
\end{tabular}

Tabel 5.5

Berekende uit- en afspoeling scenario's ten opzichte van het autonome scenario (autonoom gesteld op $100 \%)$

\begin{tabular}{|c|c|c|c|c|c|c|}
\hline Deelgebied & Huidig & Autonoom & Meer Natuur & OWD & KLV & Combi \\
\hline & \multicolumn{6}{|c|}{ Totale uit- en afspoeling stikstof } \\
\hline Nesse & $138 \%$ & $100 \%$ & $91 \%$ & $100 \%$ & $88 \%$ & $78 \%$ \\
\hline Verdoold & $117 \%$ & $100 \%$ & $97 \%$ & $85 \%$ & $88 \%$ & $74 \%$ \\
\hline Veurink & $120 \%$ & $100 \%$ & $94 \%$ & $98 \%$ & $87 \%$ & $82 \%$ \\
\hline Nesse & $53 \%$ & $100 \%$ & $100 \%$ & $100 \%$ & $94 \%$ & $94 \%$ \\
\hline Krimpenerwaard & $99 \%$ & $100 \%$ & $97 \%$ & $94 \%$ & $95 \%$ & $87 \%$ \\
\hline Verdoold & $106 \%$ & $100 \%$ & $101 \%$ & $87 \%$ & $94 \%$ & $84 \%$ \\
\hline Veurink & $94 \%$ & $100 \%$ & $98 \%$ & $99 \%$ & $94 \%$ & $92 \%$ \\
\hline
\end{tabular}

Uit de resultaten komt duidelijk naar voren dat de afname niet heel groot is. De autonome situatie geeft voor stikstof een behoorlijke afname, maar het effect van de overige scenario's zijn ten opzichte van het autonome scenario vrij beperkt. Ook voor fosfor is het effect van de scenario's op de uit- en afspoeling beperkt. In het navolgende worden de effecten van scenario's kort toegelicht.

\section{Scenario Autonoom}

De stikstof belasting loopt met zo'n 15\% terug, terwijl P of weinig verandert door de sterke buffering of zelfs wat toeneemt. Dat laatste is een gevolg van de toenemende oplading door bemesting en vooral ook aan de $\mathrm{P}$ uit weidevogelmest. Het teruglopen van stikstof heeft vooral te maken met het langzaam uitputten van de met bemesting verrijkte bodem dat al is ingezet in de berekening van de huidige situatie. De bemesting loopt vanaf 2000 terug en daardoor wordt de bodem langzaam uitgeput door het gewas. Bij fosfor is de tijd daarvoor te kort door de sterke buffering (nalevering vanuit de bodem).

\section{Scenario uitbreiding areaal natuur}

De absolute vrachten van de uit- en afspoeling zijn weergegeven in Tabel 5.6. Dit scenario geeft een relatief vrij geringe afname van de uit- en afspoeling ten opzichte van het autonome scenario. Hierbij moet worden bedacht dat per deelgebied het areaal landbouw dat in het rekenscenario is omgezet in natuur sterk verschilt (zie ook Tabel 5.2); in Veurink en Verdoold is dat respectievelijk 400 ha en 570 ha nieuwe natuur waar niet wordt bemest, in de Nesse is dat 127 ha waarbij wordt uitgegaan van bemesting volgens weidevogelbeheer. In de Krimpenerwaard is de uitbreiding slechts 6 ha. 
Daarnaast speelt ook sterk mee dat de waterpeilen worden verhoogd. Dit brengt met zich mee dat door de natte omstandigheden meer stikstof wordt afgebroken en fosfaat juist door meer oppervlakkige afstroming vaker kan afspoelen naar de sloten. Dit laatste komt ook naar voren in de berekeningen voor Verdoold, waar het scenario natuur in totaal een net iets hogere af- en uitspoeling geeft dan het autonome scenario.

\section{Tabel 5.6}

Absolute vrachten uit- en afspoelingscenario Natuur ten opzichte van het autonome scenario

\begin{tabular}{|c|c|c|c|c|c|c|c|c|}
\hline \multirow[t]{2}{*}{ Deelgebied } & \multirow{2}{*}{$\begin{array}{l}\text { Areaal } \\
\text { ha }\end{array}$} & \multirow{2}{*}{$\begin{array}{l}\text { Extra } \\
\text { natuur } \\
\text { ha }\end{array}$} & \multicolumn{2}{|l|}{ Autonoom } & \multicolumn{2}{|c|}{ Scenario natuur } & \multicolumn{2}{|c|}{$\begin{array}{l}\text { Afname scenario } \\
\text { natuur }\end{array}$} \\
\hline & & & $\mathbf{N}$ ton jaar $^{-1}$ & P ton jaar ${ }^{-1}$ & N ton jaar ${ }^{-1}$ & P ton jaar ${ }^{-1}$ & $\mathbf{N}$ ton jaar $^{-1}$ & P ton jaar ${ }^{-1}$ \\
\hline Krimpenerwaard & 3.125 & 6 & 34,3 & 5,9 & 33,8 & 5,7 & 0,5 & 0,2 \\
\hline Verdoold & 5.219 & 610 & 112,6 & 16,7 & 109,0 & 16,8 & 3,6 & $-0,1$ \\
\hline
\end{tabular}

Scenario Kringlooplandbouw veenweide (KLV)

Zoals aangegeven, is voor dit scenario (in de figuren en tabellen afgekort als KLV) aangenomen dat ten opzichte van de autonome situatie het bodemoverschot bij de melkveebedrijven voor stikstof afneemt met $60 \mathrm{~kg} \mathrm{~N} \mathrm{ha}^{-1}$ en voor fosfor met $10 \mathrm{~kg} \mathrm{P} \mathrm{ha}^{-1}$. Ten behoeve van de interpretatie is in Tabel 5.7 de absolute af- en uitspoeling van het scenario weergegeven. Uit deze tabel blijkt dat uit- en afspoeling van stikstof ten opzichte van het autonome scenario zo'n $15 \%$ afneemt. Als gekeken wordt naar het areaal waarvoor de daling van het stikstof bodemoverschot in de modelberekening is doorgevoerd ('areaal KLV' in de tabel), werkt de afname van het overschot voor stikstof $\left(60 \mathrm{~kg} \mathrm{ha}^{-1}\right)$ ca. 3 à 6,5\% door in de verlaagde uit- en afspoeling. Voor fosfor is dit effect minder groot. Bekend is ook dat de uit- en afspoeling van fosfor minder door het bodemoverschot wordt gestuurd.

\section{Tabel 5.7}

Absolute vrachten uit- en afspoelingscenario Kringlooplandbouw Veenweide (KLV) ten opzichte van het autonome scenario

\begin{tabular}{|c|c|c|c|c|c|c|c|c|}
\hline \multirow[t]{2}{*}{ Deelgebied } & \multirow{2}{*}{$\frac{\text { Areaal }}{\text { ha }}$} & \multirow{2}{*}{$\begin{array}{l}\text { Areaal KLV } \\
\text { ha }\end{array}$} & \multicolumn{2}{|l|}{ Autonoom } & \multicolumn{2}{|c|}{ Scenario KLV } & \multicolumn{2}{|c|}{ Afname scenario KLV } \\
\hline & & & $\mathbf{N}$ ton jaar ${ }^{-1}$ & P ton jaar ${ }^{-1}$ & $\mathbf{N}$ ton jaar $^{-1}$ & P ton jaar ${ }^{-1}$ & $\mathbf{N}$ ton jaar $^{-1}$ & P ton jaar ${ }^{-1}$ \\
\hline Nesse & 553 & 321 & 4,9 & 0,6 & 4,3 & 0,6 & 0,6 & 0,0 \\
\hline Verdoold & 5.219 & 4.103 & 112,6 & 16,7 & 99,0 & 15,6 & 13,6 & 1,1 \\
\hline Veurink & 4.539 & 2.851 & 83,3 & 13,5 & 72,1 & 12,7 & 11,2 & 0,8 \\
\hline
\end{tabular}

\section{Scenario onderwaterdrainage (OWD)}

In dit scenario is gerekend met 1.985 ha onderwaterdrainage. Dit is ongeveer $20 \%$ van het areaal grasland dat landbouwkundig wordt beheerd. Tabel 5.8 geeft de absolute af- en uitspoeling weer van het scenario en de afname hiervan ten opzichte van het autonome scenario. De afname is het grootst in de deelgebieden waar het meeste areaal onderwaterdrainage is ingevoerd. In deelgebied Verdoold is volgens de berekeningen onderwaterdrainage het effectiefst. Daar is de afname van de uit- en afspoeling per ha onderwaterdrainage het grootst; per ha onderwaterdrainage $12,4 \mathrm{~kg} \mathrm{~N}$ en $1,6 \mathrm{~kg}$ P. In de andere deelgebieden is onderwaterdrainage minder effectief (circa $8 \mathrm{~kg} \mathrm{~N}$ en $1 \mathrm{~kg} P$ per ha onderwaterdrainage). 
Tabel 5.8

Absolute vrachten uit- en afspoelingscenario Onderwaterdrainage (OWD) ten opzichte van het autonome scenario

\begin{tabular}{|c|c|c|c|c|c|c|c|c|}
\hline \multirow[t]{2}{*}{ Deelgebied } & Areaal & $\begin{array}{l}\text { Areaal } \\
\text { OWD }\end{array}$ & Autonoom & & \multicolumn{2}{|c|}{ Scenario OWD } & \multicolumn{2}{|c|}{$\begin{array}{l}\text { Afname scenario } \\
\text { OWD }\end{array}$} \\
\hline & ha & ha & $\mathbf{N}$ ton jaar ${ }^{-1}$ & $P$ ton jaar ${ }^{-1}$ & $\mathbf{N}$ ton jaar ${ }^{-1}$ & P ton jaar ${ }^{-1}$ & $\mathbf{N}$ ton jaar ${ }^{-1}$ & $P$ ton jaar ${ }^{-1}$ \\
\hline Krimpenerwaard & 3.125 & 426 & 34,3 & 5,9 & 31,1 & 5,5 & 3,2 & 0,4 \\
\hline Verdoold & 5.219 & 1.399 & 112,6 & 16,7 & 95,2 & 14,5 & 17,5 & 2,2 \\
\hline
\end{tabular}




\section{Discussie modelberekeningen af- en uitspoeling}

\subsection{Modelberekeningen waterbalans}

De waterhuishouding van elk waterbalansgebied is berekend met de SWAP-modellen van alle onderscheiden rekenplots. De gedetailleerde modellering van het landsysteem, gegeven de randvoorwaarden als watertermen neerslag minus verdamping en kwel of wegzijging, en het opgelegde peil leiden tot wateruitwisseling tussen land en oppervlaktewater. Samen met dezelfde randvoorwaarden neerslag minus verdamping en kwel/wegzijging voor het oppervlaktewater leidt dat tot uitmalen en inlaten van water. Voor hoeveelheden bemalen en ingelaten water zijn gegevens beschikbaar gesteld door HHSK die zijn verkregen door meten gecombineerd met modelleren. Dat houdt in dat ze behept zijn met een bepaalde, onbekende onzekerheid.

De SWAP-uitkomsten zijn geïnterpreteerd tot netto hoeveelheden uit te malen of in te laten water door ze te verrekenen met de landoppervlakten van de plots en door neerslag en kwel op, en verdamping en wegzijging uit het oppervlaktewater te berekenen gegeven het percentage oppervlaktewater, en deze termen mee te nemen in de waterbalans van het oppervlaktewater. Op deze manier is de juistheid van de SWAP-berekeningen getoetst en verbeterd door bijstelling van grootheden. Aandachtspunt tijdens het kalibreren is enerzijds dat de uit metingen afgeleide debieten een bepaalde onzekerheid hebben, met name met betrekking tot de hoeveelheden inlaatwater. Anderzijds is bij de modellering uitgegaan van een vast peil gedurende het hele jaar dat is afgeleid uit de droogleggingskaart. In werkelijkheid fluctueert het peil afhankelijk van het weer en hoe de waterbeheerder hierop anticipeert. De schommelingen in het peil hebben een dempend effect op de wateruitwisseling tussen land en oppervlaktewater: bij veel regen stijgt het oppervlaktewaterpeil, wat een remmende werking op de waterafvoer vanuit het land betekent; bij een grote verdampingsvraag daalt het peil, wat de infiltratie van slootwater in de landbodem remt.

Het bleek dan ook steeds nodig om het model bij te sturen op basis van de bemalings- en inlaatgegevens van HHSK. Dit is vooral gedaan door de randvoorwaarden bij te stellen: de stijghoogte in het eerste watervoerende pakket en de drooglegging. Dit is eenvoudiger en eenduidiger dan de procesparameters van het landsysteem bij te stellen. Een belangrijk argument hiervoor is dat beide grootheden ondanks de detailkaarten vrij onzeker zijn. Dat geldt vooral voor de stijghoogten, omdat het ruimtelijke patroon hiervan is verkregen door interpolatie tussen de beschikbare

stijghoogtebuizen. Vooral in de gebieden waar de stijghoogtegradiënten groot zijn, is deze interpolatie vrij onzeker. Daarnaast is ook temporeel geïnterpoleerd met bijgaande onzekerheden. De buisgegevens zijn gebruikt om een sinusvormig verloop in de tijd te fitten waarvan de parameters in het model worden gebruikt. In veel gevallen was het gemeten verloop in stijghoogten niet mooi sinusvormig en/of was er geen constante basislijn aanwezig, maar vertoonde deze een duidelijk dalende of stijgende trend. Beide randvoorwaarden, stijghoogten en drooglegging, zijn nodig in het model als waarden ten opzichte van het maaiveld. En juist het maaiveld in veenweiden is erg onzeker; in de tijd door maaivelddaling en in de ruimte door ongelijke maaiveldligging door ongelijke maaivelddaling binnen percelen. Bijstellen van de drooglegging is terughoudend gebeurd, meestal binnen $5 \mathrm{~cm}$, behalve bij extreme, moeilijk te verantwoorden droogleggingen. De stijghoogten zijn over het algemeen binnen $10 \mathrm{~cm}$ aangepast. Voor rekenplots met buizen waarin een duidelijke trend in het verloop van de stijghoogte zichtbaar was, is een extra functionaliteit in SWAP ingebouwd om de stijghoogte in de tijd te laten verlopen. In andere gevallen was er een duidelijke trend in de tijd van het verschil tussen berekende debieten en de debieten van HHSK. Vaak was de trend dat de berekende debieten achterbleven. Dat is geïnterpreteerd als het gevolg van niet meenemen van de maaivelddaling in het model, waardoor de stijghoogte relatief diep blijft en wegzijging wordt overschat of kwel onderschat, en afvoer naar het oppervlaktewater onderschat.

In die gevallen is er een licht stijgende trend van de stijghoogte in het model opgenomen van enkele millimeters tot enkele centimeters per jaar. Deze inbreng van een verloop in de tijd van de stijghoogte gaf aanzienlijke verbeteringen van de modelresultaten. 
In waterbalansgebied de Krimpenerwaard, waarin de oevergrondwaterwinning nabij Bergambacht is gesitueerd, is voor de rekenplot 'Drechtvaaggrond met wegzijging en agrarisch grasland' een aparte aanpassing aan de stijghoogte gepleegd. Deze is met ruim $2 \mathrm{~m}$ verlaagd tot $320 \mathrm{~cm}$ beneden maaiveld om de grote inlaat die de inlaatdebieten van HHSK aangaven te kunnen berekenen. Zonder deze aanpassing berekende het model gemiddeld ongeveer drie miljoen kubieke meter per jaar te weinig inlaat. Deze hoeveelheid komt overeen met ruim 20\% van de totale onttrokken hoeveelheid grondwater voor de waterwinning van ruim $14 \mathrm{Mm}^{3}$ per jaar (Spijker et al., 2009). Het onttrokken water bestaat voor $60 \%$ uit rivierwater, voor $20 \%$ uit water uit de uiterwaarden van de Lek en voor $20 \%$ uit polderwater (Spijker et al., 2009). Voor de laatste $20 \%$ is water vanuit waterbalansgebied Krimpenerwaard nodig, wat leidt tot een extra onttrekkingspost op de waterbalans die moet worden aangevuld met extra netto-inlaat.

Op deze manier zijn berekeningen van de waterbalansen van het landsysteem verkregen die, gezien de onzekerheden, goed overeenstemmen met hetgeen uit de debieten van HHSK kon worden afgeleid. Ten opzichte van de eerder uitgevoerde modelleringsstudie van de Krimpenerwaard van Monitoring Stroomgebieden (Van Gerven et al., 2011) ligt in deze berekeningen veel meer detail besloten vanwege de grotere mate van detail in de randvoorwaarden drooglegging en stijghoogten en daarmee gedetailleerde kwel/wegzijgingspatronen. Dat impliceert ook dat het bereik in berekende debieten en kwel en wegzijging groter is. In de slechts drie rekenplots van het landsysteem van Monitoring Stroomgebieden was vooral de onderrand, de kwel en wegzijging, sterk uitgemiddeld. Dat geldt vooral voor de sterke wegzijging aan de noordrand van het gebied. Deze grotere mate van detail in waterstromen ten opzichte van Monitoring Stroomgebieden was een hoofddoel en -opdracht van deze modelstudie. De conclusie is dat dat doel is bereikt. Daarnaast was ook de toetsing aan gegevens van HHSK gedetailleerder dan bij Monitoring Stroomgebieden: meer aaneengesloten jaarreeksen met dagcijfers van de in- en uitlaatdebieten, waarbij uitmaalcijfers door HHSK zijn gecorrigeerd voor verschillen tussen gemaalcapaciteit en werkelijke debieten en waarbij schattingen over de hoeveelheden inlaatwater beter zijn onderbouwd door deze (mede) te baseren op resultaten van een hydrologische Sobek-modellering.

\subsection{Modelberekeningen nutriëntenbronnen}

\section{Modelberekeningen uit- en afspoeling nutriënten}

Een belangrijke basis voor het modelleren van de uit- en afspoeling is de kwel en wegzijging. De kalibratieresultaten van de waterbalans geven vertrouwen dat deze belangrijke randvoorwaarde zowel ruimtelijke als temporeel goed in het modelinstrumentarium is meegenomen. Gelet op de bijkomende onzekerheden, zijn vooral de gedane aannames rond de bemesting en nutriëntenopname door het gewas bepalend voor de berekende uit- en afspoeling. De bemesting in de referentieperiode (20002014 ) is redelijk goed bekend, mede door inbreng van gebiedskennis PPP-agro Advies. De gewasopname die aan het nutriëntenuitspoelingsmodel ANIMO is opgelegd voor de huidige situatie van de landbouwgronden, is verkregen uit de studie Monitoring Stroomgebieden. Deze zijn in de onderhavige studie getoetst aan de hand van praktijkgegevens van praktijkonderzoek naar bodem en gewasopbrengsten in veenweiden.

Voor natuurgrasland is de opname conform de aanpak in STONE niet opgelegd vanuit externe berekeningen, maar wordt door ANIMO zelf berekend. In deze berekeningen zijn verschillende onzekere aannamen gedaan die niet per se van kracht zijn voor het gebied van deze studie. Daarnaast zijn de hoeveelheid en de samenstelling van de ruwe stalmest nogal onzeker zoals deze zijn geschat door een deskundige landbouwvoorlichter. Vooral de hoeveelheid fosfor in deze mest lijkt hoog. De bemesting voor weidevogelgrasland komt, afgaande op de aangehouden hoeveelheden en samenstelling stalmest, uit op bijna $200 \mathrm{~kg} \mathrm{~N} \mathrm{ha}^{-1} \mathrm{jaar}^{-1}$ en $28 \mathrm{~kg} \mathrm{P}^{-1} \mathrm{jaar}^{-1}$. Ten opzichte van de aangenomen bemesting voor landbouwgronden in de autonome situatie (340 kg N ha-1 $\mathrm{jaar}^{-1}$ en $36 \mathrm{~kg} \mathrm{P} \mathrm{ha}^{-1}$ jaar $^{-1}$ ), zijn de aangehouden mestgiften voor de natuurgraslanden (weidevogel) opvallend hoog; $59 \%$ van de $\mathrm{N}$-bemesting van landbouwgronden en maar liefst $78 \%$ voor $\mathrm{P}$. 
Deze giften komen vooral voort uit hetgeen wettelijk (en dus maximaal) is toegestaan. De nog relatief hoge mestgiften, de relatief laag berekende gewasopname en de hoge opladingsgraad met nutriënten vanuit het verleden van voormalige landbouwgebieden die worden omgezet in weidevogelland, gecombineerd met de vaak geringere nieuw ingestelde drooglegging, leidt tot een relatief grote uitspoeling van nutriënten.

Voor de autonome situatie is de gewasopname in de landbouwpercelen doorgetrokken vanuit de huidige situatie aan het einde van deze periode die dezelfde bemesting heeft. Omdat deze gewasopname niet is berekend, zoals bij de huidige gewasopname, is deze opname nogal onzeker. Maar deze berekeningen betreffen een scenario waarin ook andere zaken als het weer onzeker zijn. In die zin is de gebruikte schatting verantwoord.

\section{Nutriëntenbelasting vanuit overige bronnen}

Naast uit- en afspoeling wordt het oppervlaktewater vooral met nutriënten belast door inlaatwater, atmosferische depositie en, zij het in mindere mate, rwzi's. De nutriëntenvrachten die voor inlaat zijn berekend, zijn gebaseerd op de gegevens van HHSK: inlaatdebieten en concentraties die per inlaatpunt representatief worden geacht. De aangehouden concentraties van het water in de Lek en de Vlist werken sterk door in de vrachten. Deze zijn redelijk goed bekend door de beschikbare monitoring en de wetenschap dat de concentraties, gelet op de omvang en stroming van deze rivieren, niet sterk van plaats tot plaats (en dus per inlaatpunt) zal verschillen. Voor Veurink, Nesse en Verdoold is het inlaatwater afkomstig van de Krimpenerwaard en water dat onderling wordt uitgewisseld. Voor dit doorvoerwater heeft HHSK de concentraties voornamelijk gebaseerd op de gemiddelde waterkwaliteit van het deelgebied dat dit water doorvoert. De huidige waterkwaliteitsmonitoring is niet voldoende uitgebreid om hoogfrequent in het jaar metingen vlakbij het doorvoerpunt te verzamelen die representatief zijn voor de kwaliteit van het inlaatwater.

De onzekerheden over de omvang van de overige nutriëntenbronnen zijn vrij gering; de lozingen van rwzi's worden betrouwbaar bepaald op basis van metingen en de atmosferische $\mathrm{N}$-depositie is redelijk goed bekend. Vooral het areaal open water is een belangrijk factor in de vrachtberekeningen van de atmosferische depositie. Zoals aangegeven, rekent EmissieRegistratie voor de deelgebieden met duidelijk te lage open water arealen. Deze getallen zijn in de onderhavige studie hierop gecorrigeerd (naar boven bijgesteld).

Een belangrijke factor in de nutriëntenbalans is de retentie; de hoeveelheid nutriënten die in de sloten en andere regionale polderwateren achterblijft door afbraak, plantenopname en vastlegging aan het sediment. In de Monitoring Stroomgebiedenstudie is hier veel aandacht aan besteed en met het daarbij gebruikte waterkwaliteitsmodel (Nuswa-Light) is een retentie van $50 \%$ voor stikstof en fosfor afgeleid. In de ECHO-methode wordt gerekend met een uit het onderzoek PLONS afgeleide empirische relatie o.b.v. globale kenmerken van het watersysteem. De retentie kan per gebied beter geschat worden door apart te kijken naar de verblijftijden van het water en de routing en verblijftijden van het inlaatwater. Voor stikstof levert deze methode een veel lagere retentie (15 à 25\%). Er is daarom gekozen om voor stikstof een retentie aan te nemen van $50 \%$. Voor fosfor levert de ECHO methode $50 \%$ retentie voor diffuse bronnen en $20 \%$ voor puntbronnen dat redelijk aansluit bij de retentie zoals die in Monitoring Stroomgebieden is afgeleid.

Hoewel er diverse onzekerheden in de bronnenanalyse zijn, geeft de vergelijking van de berekende en uit metingen afgeleide nutriëntenbalans redelijk vertrouwen in de berekende bronnenanalyse van de huidige situatie.

\section{Modelberekeningen scenario's}

De effecten van de scenario's zijn gekwantificeerd door een autonome situatie te definiëren en de scenario's door te rekenen voor de periode 2015-2029, waarbij voor het klimaat (meteo) gerekend is met de meteo van 2000-2014. Effecten van klimaatverandering zijn derhalve niet meegenomen. Dit zou ook gepaard gaan met grote onzekerheden, want belangrijke aannames die gedaan moeten worden om effecten van klimaatverandering op de nutriënten uit- en afspoeling te kwantificeren, zijn onzekerheden, zoals de invloed van $\mathrm{CO}_{2}$-verandering op de gewasgroei, de invloed van weersextremen op oppervlakkige afstroming en droogte. 
Belangrijk voor de interpretatie is dat in 2029 voor de nutriëntenhuishouding van de bodem nog geen evenwichtssituatie zal zijn bereikt. Dit betekent dat de uiteindelijke afname van de uit- en afspoeling groter zal zijn dan hetgeen in de onderhavige studie is bepaald op basis van het rekenkundige gemiddelde over de periode 2015-2029. Vooral voor fosfor geldt dat de huidige opgeladen fosfaattoestand lang (decennia) kan doorwerken in de uit- en afspoeling.

Voor onderwaterdrainage zijn nog weinig 'harde' meetgegevens uit veldexperimenten beschikbaar om het langjarige effect uit af te leiden. Met name de mate waarin slootwater via de buisdrainage doordringt in het bodemprofiel kan in de praktijk sterk afwijken van hetgeen theoretisch (en dus ook in het model) wordt verondersteld.

Voor kringlooplandbouw zal het effect sterk afhangen van de wijze waarop de melkveehouders het bodemoverschot weten terug te dringen. Dit zal in de praktijk sterk per bedrijf verschillen.

Voor het natuurscenario zijn de berekende effecten vooral afhankelijk van de aannames over de stalmestmestgiften bij weidevogelbeheer en de gewasopname.

De grote verschillen in kwel en wegzijging brengen met zich mee dat de effecten van de maatregelen sterk van plaats tot plaats verschillen. In gebieden waar een sterke wegzijging plaatsvindt, zoals in het noordelijk deel van de Nesse en delen van de Krimpenerwaard rond de drinkwaterwinning, is de netto-uitspoeling van de nutriënten gering, omdat een significant deel van de nutriënten vanuit de sloten weer infiltreert naar de diepere bodem.

De maatregelen hebben een positieve invloed op de uit- en afspoeling, hetgeen in de beschouwing van de maatregelen kwantitatief in beeld is gebracht. Voor het totale effect dient te worden bedacht dat de maatregelen ook een positief effect hebben op de kwaliteit van het water dat van het ene naar het andere deelgebied wordt doorgevoerd. 


\section{$7 \quad$ Conclusies en aanbevelingen}

\subsection{Conclusies}

Voor de Krimpenerwaard is een modelinstrumentarium opgebouwd dat de waterbalans en nutriëntenbalans transparant in beeld brengt voor de vier afwateringsgebieden binnen de Krimpenerwaard. Het modelinstrumentarium is opgebouwd op de modellen SWAP en Animo die ook zijn toegepast in de voorgaande studie Monitoring Stroomgebieden, deelgebied Krimpenerwaard. Ten opzichte van deze studie is de schematisatie sterk verfijnd en is gerekend met nieuwe (beter betrouwbare) inzichten voor het inlaatwater en uitlaat (kwantiteit en kwaliteit).

Op het niveau van de vier afwateringsgebieden is een goede fit tussen de berekende en uit metingen afgeleide waterbalans. De berekende nutriëntenbelasting komt redelijk overeen met hetgeen uit de metingen kan worden afgeleid. Alleen voor deelgebied Veurink lijkt de berekende belasting met fosfor te worden onderschat en voor de Nesse de stikstofbelasting te worden overschat. De resultaten van de berekende water- en nutriënten balansen bieden vertrouwen in de analyse van de herkomst en de doorgerekende scenario's.

De af- en uitspoeling van landbouw en natuurgronden vormt voor zowel stikstof als fosfor het merendeel van de totale belasting. Wel zijn er tussen de deelgebieden grote verschillen. In de Krimpenerwaard vormt inlaatwater vanuit de Lek een relatief grote bron. In de Nesse is relatief veel natuur en verdwijnt een significant deel van de fosforbelasting door wegzijging vanuit de sloten naar de landbouwbodems.

De herkomst van de belasting is onderverdeeld in beïnvloedbare en niet/moeilijk beïnvloedbare bronnen (Tabel 4.5). Een significant aandeel is beïnvloedbaar, vooral in de deelgebieden Krimpenerwaard en Verdoold. Verbetering van de kwaliteit van het inlaatwater en vermindering van inlaathoeveelheden kunnen een significant directe afname van de nutriëntenbelasting geven. Maatregelen om de uit- en afspoeling door minder mestgebruik of uitmijnen te verminderen, zullen niet snel effect hebben op de nutriëntenbelasting en daarbij speelt ook dat maar ongeveer de helft van de uit- en afspoeling afkomstig is van historische en actuele bemesting.

In de autonome situatie daalt de af- en uitspoeling van stikstof zo'n 15\%, terwijl fosfor of weinig verandert door de sterke buffering of zelfs wat toeneemt. Dat laatste is een gevolg van de toenemende oplading door bemesting, ook in weidevogelnatuur. De afname van stikstof komt door het langzaam uitputten van de met bemesting verrijkte bodem dat al is ingezet in de berekening van de huidige situatie. De bemesting loopt vanaf 2000 terug en daardoor wordt de bodem langzaam uitgeput door het gewas. Bij fosfor is de tijd daarvoor te kort door de sterke buffering (nalevering vanuit de bodem).

Door verruiming van het areaal natuur, aanleg van onderwaterdrainage op koopveengronden en lagere bodemoverschotten door kringlooplandbouw neemt de af- en uitspoeling verder af. Deze afname is ten opzichte van de autonome situatie met de voor deze scenario's gehanteerde uitgangspunten niet heel groot (circa 10 à 20\% verdere afname). Deze afname levert verder ook een verbetering van de kwaliteit van het water dat van het ene naar het andere deelgebied wordt doorgevoerd. 


\subsection{Aanbevelingen}

Met de berekende onderverdeling in wel/niet beïnvloedbare bronnen kunnen keuzes voor het afleiden van achtergrondconcentraties, eventueel het bijstellen van waterkwaliteitsdoelen en inzet voor maatregelen worden onderbouwd. Hoewel de effecten voor de beschouwde termijn niet heel groot lijken, wordt aanbevolen om in te zetten op kringlooplandbouw en onderwaterdrainage.

Kringlooplandbouw levert namelijk in de regel voor de melkveehouders een positief bedrijfsresultaat en onderwaterdrainage draagt naast verbetering van de waterkwaliteit ook bij aan het afremmen van maaivelddaling.

Voor de locatiekeuze van maatregelen wordt aanbevolen om specifiek te kijken naar kwel- en wegzijgingspatronen die sterk bepalend zijn voor de effectiviteit in termen van afname van de nutriëntenbelasting.

Voor het beheer en mogelijke uitbreiding van natuur wordt aanbevolen om specifiek aandacht te besteden aan mogelijke vermindering van mestgiften voor weidevogelbeheer. Verder wordt aanbevolen om de mogelijkheden voor verlaging van bodemoverschotten en de daarbij te verwachten afname van de uit- en afspoeling te onderzoeken aan de hand van bedrijfsbezoeken door landbouwadviseurs en toepassing van de KringloopWijzer, inclusief de in ontwikkeling zijnde uitbreiding daarvan met de waterkwaliteit module Hydrometra. De retentie is een belangrijke post in de nutriëntenbalans. Aanbevolen wordt om nader (model)onderzoek te verrichten naar deze retentie en naar mogelijkheden om deze te vergroten. 


\section{Literatuur}

Boekel, E.M.P.M. van; Roelsma, J.; Massop, H.T.L.; Mulder, H.M.; Jansen, P.C.; Renaud, L.V.; Hendriks, R.F.A.; Schipper, P.N.M. - 2015. Achtergrondconcentraties in het oppervlaktewater van HHNK: Hoofdrapport: Analyse achtergrondconcentraties voor stikstof en fosfor op basis van wateren nutriëntenbalansen voor het beheergebied van HHNK. Alterra-rapport 2475 - p. 129.

Boekel, E.M.P.M. van; Schipper, P.N.M.; Hendriks, R.F.A.; Massop, H.T.L.; Mulder, H.M.; Roelsma, J. 2013. Herkomst nutriëntenbelasting afvoergebieden HDSR, pilotstudie ECHO: regionale bronnenanalyse nutriëntenbelasting: Keulevaart, Eiland van Schalkwijk, Langbroekerwetering en Zegveld. Alterra-rapport 2408 - p. 108.

Gerven, L.P.A. van; Grift, B. van der; Hendriks, R.F.A.; Mulder, H.M. 2011. Nutriëntenhuishouding in de bodem en het oppervlaktewater van de Krimpenerwaard: bronnen, routes en sturingsmogelijkheden. Alterra-rapport 2220.

Hendriks, R.F.A., 1991. 'Afbraak en mineralisatie van veen. Literatuuronderzoek'. Rapport 199. DLO-Staring Centrum, Wageningen.

Hendriks, R.F.A., 1997. Oorzaken van diffuse stikstof- en fosforbelasting van het oppervlaktewater in veenweidegebieden. H2O (30) 1997, nr. 3: 66-69.

Hendriks, R.F.A., 2003. Bemesting hoofdoorzaak van eutrofe veensloten? H2O (36) 2003, nr. 11: 33-36.

Muhammetoglu, A. and S. Soyupak, 2000. A three-dimensional water quality-macrophyte interaction model for shallow lakes. Ecological Modelling 133, 161-180.

Nutriënten adviesgroep Waterschappen Rijn-West, 2012. Deelrapport 1: Stappenplan Nutriëntenaanpak. Projectgroep Rijn-West, 2012. "Nutriëntenmaatwerk in de polder, advies Nutriëntenproject Rijn-West". Concept-eindadvies versie 9 oktober 2012.

Roijackers, R., S. Szabó en M. Scheffer, 2004. Experimental analysis of the competition between algae and duckweed. Hydrobiologie 160, 401-412.

Schipper, Peter, Oscar Schoumans, Piet Groenendijk, Erwin van Boekel. Nutriëntenbelasting oppervlaktewater; Herkomst en bijdrage landelijke gebied. Notitie ter ondersteuning KRW-Rijn West aanpak Nutriënten - 11-5-2012. Alterra WUR Wageningen.

Siderius, C., P. Groenendijk, L.P.A. van Gerven, M.H.J.L. Jeuken en A.A.M.F.R Smit, 2008. Process description of NuswaLite; a simplified model for the fate of nutrients in surface waters. Alterra Wageningen, Alterra, Alterra Report 1226.2.

Spijker, J., R. Lieste, M.C. Zijp en A.C.M. de Nijs, 2009. Conceptuele modellen voor de Kaderrichtlijn Water en de Grondwaterrichtlijn. RIVM. Rapport 607300010/2009.

Tol-Leenders, T.P. van; Grift, B. van der; Walvoort, D.J.J.; Janssen, G.M.C.M.; Rozemeijer, J.; Marsman, A.; Mulder, H.M.; Bolt, F.J.E. van der; Schoumans, O.F. 2011. Monitoring van nutriënten in het oppervlaktewater van stroomgebieden: analyse van metingen in de gebieden Drentse Aa, Schuitenbeek, Krimpenerwaard en Quarles van Ufford. Alterra-rapport 2222 - p. 98.

Veraart, A.J., J.J.M. de Klein en M. Scheffer, 2011b. Warming Can Boost Denitrification Disproportionately Due to Altered Oxygen Dynamics. PLoS ONE 6(3): e18508.

Witteveen \& Bos 2015, Deventer. "Watersysteemstudie Krimpen a/d IJssel". 


\section{Bijlage 1 Overzicht rekenplots}

\section{Tabel B1.1}

Initiële rekenplots op basis van klassen meteo, landgebruik, bodemtype en kwel

\begin{tabular}{|c|c|c|c|c|c|}
\hline ID & Meteogebied & Grondgebruik & Bodemtype & Kwelklasse & ha \\
\hline 45 & Verdoold & Grasland & Koopveengronden & Verdoold: intermediair & 1.369 \\
\hline 50 & Verdoold & Grasland & Koopveengronden & Verdoold: kwel & 1.310 \\
\hline 138 & Veurink & Grasland & Koopveengronden & Veurink: intermediair & 580 \\
\hline 129 & Veurink & Grasland & Koopveengronden & Veurink: wegzijging & 474 \\
\hline 29 & Krimpenerwaard & Grasland & Waard/Weideveengronden & Krimpenerwaard: wegzijging & 412 \\
\hline 165 & Veurink & Grasland & Waard/Weideveengronden & Veurink: kwel & 372 \\
\hline 44 & Verdoold & Natuurgrasland & Koopveengronden & Verdoold: wegzijging & 345 \\
\hline 174 & Veurink & Grasland & Kleigronden & Veurink: kwel & 333 \\
\hline 109 & Krimpenerwaard & Grasland & Kleigronden & Krimpenerwaard: kwel & 298 \\
\hline 46 & Verdoold & Natuurgrasland & Koopveengronden & Verdoold: intermediair & 290 \\
\hline 49 & Verdoold & Water & Koopveengronden & Verdoold: kwel & 267 \\
\hline 99 & Krimpenerwaard & Grasland & Koopveengronden & Krimpenerwaard: wegzijging & 260 \\
\hline 147 & Veurink & Bebouwd & Bebouwd & Veurink: intermediair & 258 \\
\hline 170 & Veurink & Bebouwd & Bebouwd & Veurink: kwel & 240 \\
\hline 114 & Veurink & Bebouwd & Bebouwd & Veurink: wegzijging & 210 \\
\hline 3 & Verdoold & Grasland & Waard/Weideveengronden & Verdoold: wegzijging & 208 \\
\hline 116 & Veurink & Grasland & Kleigronden & Veurink: wegzijging & 195 \\
\hline 52 & Verdoold & Bebouwd & Koopveengronden & Verdoold: kwel & 138 \\
\hline 141 & Veurink & Natuurgrasland & Koopveengronden & Veurink: intermediair & 120 \\
\hline 184 & Veurink & Bebouwd & Kleigronden & Veurink: kwel & 108 \\
\hline 164 & Veurink & Grasland & Kleigronden & Veurink: intermediair & 100 \\
\hline 56 & Verdoold & Natuurgrasland & Koopveengronden & Verdoold: kwel & 100 \\
\hline 154 & Veurink & Bebouwd & Waard/Weideveengronden & Veurink: intermediair & 98 \\
\hline 92 & Krimpenerwaard & Grasland & Koopveengronden & Krimpenerwaard: kwel & 92 \\
\hline 111 & Krimpenerwaard & Bebouwd & Kleigronden & Krimpenerwaard: kwel & 85 \\
\hline 156 & Veurink & Bebouwd & Waard/Weideveengronden & Veurink: wegzijging & 84 \\
\hline 6 & Verdoold & Grasland & Waard/Weideveengronden & Verdoold: intermediair & 83 \\
\hline 132 & Veurink & Natuurgrasland & Koopveengronden & Veurink: wegzijging & 75 \\
\hline 43 & Verdoold & Water & Koopveengronden & Verdoold: intermediair & 74 \\
\hline 53 & Verdoold & Bebouwd & Koopveengronden & Verdoold: intermediair & 63 \\
\hline 166 & Veurink & Natuurgrasland & Waard/Weideveengronden & Veurink: kwel & 57 \\
\hline 112 & Krimpenerwaard & Natuurgrasland & Koopveengronden & Krimpenerwaard: wegzijging & 56 \\
\hline 7 & Verdoold & Bebouwd & Bebouwd & Verdoold: wegzijging & 54 \\
\hline 62 & Krimpenerwaard & Grasland & Kleigronden & Krimpenerwaard: intermediair & 48 \\
\hline
\end{tabular}




\begin{tabular}{|c|c|c|c|c|c|}
\hline ID & Meteogebied & Grondgebruik & Bodemtype & Kwelklasse & ha \\
\hline 37 & Krimpenerwaard & Bebouwd & Waard/Weideveengronden & Krimpenerwaard: intermediair & 43 \\
\hline 158 & Veurink & Natuurgrasland & Koopveengronden & Veurink: kwel & 41 \\
\hline 151 & Veurink & Bebouwd & Koopveengronden & Veurink: intermediair & 41 \\
\hline 11 & Verdoold & Bebouwd & Kleigronden & Verdoold: wegzijging & 40 \\
\hline 74 & Krimpenerwaard & Natuurgrasland & Koopveengronden & Krimpenerwaard: intermediair & 40 \\
\hline 83 & Krimpenerwaard & Bebouwd & Waard/Weideveengronden & Krimpenerwaard: kwel & 39 \\
\hline 76 & Krimpenerwaard & Water & Koopveengronden & Krimpenerwaard: intermediair & 39 \\
\hline 173 & Veurink & Bebouwd & Waard/Weideveengronden & Veurink: kwel & 38 \\
\hline 172 & Veurink & Natuurgrasland & Kleigronden & Veurink: kwel & 31 \\
\hline 31 & Krimpenerwaard & Bebouwd & Bebouwd & Krimpenerwaard: intermediair & 30 \\
\hline 137 & Veurink & Bebouwd & Koopveengronden & Veurink: wegzijging & 29 \\
\hline 75 & Krimpenerwaard & Bebouwd & Koopveengronden & Krimpenerwaard: intermediair & 28 \\
\hline 60 & Krimpenerwaard & Bebouwd & Kleigronden & Krimpenerwaard: wegzijging & 28 \\
\hline 34 & Krimpenerwaard & Water & Waard/Weideveengronden & Krimpenerwaard: intermediair & 28 \\
\hline 47 & Verdoold & Water & Koopveengronden & Verdoold: wegzijging & 28 \\
\hline 140 & Veurink & Water & Koopveengronden & Veurink: intermediair & 28 \\
\hline 176 & Veurink & Water & Kleigronden & Veurink: kwel & 26 \\
\hline 27 & Krimpenerwaard & Bebouwd & Waard/Weideveengronden & Krimpenerwaard: wegzijging & 26 \\
\hline 72 & Krimpenerwaard & Natuurgrasland & Waard/Weideveengronden & Krimpenerwaard: intermediair & 26 \\
\hline 110 & Krimpenerwaard & Grasland & Bebouwd & Krimpenerwaard: kwel & 25 \\
\hline 153 & Veurink & Bebouwd & Kleigronden & Veurink: intermediair & 23 \\
\hline 160 & Veurink & Water & Koopveengronden & Veurink: kwel & 23 \\
\hline 168 & Veurink & Natuurgrasland & Waard/Weideveengronden & Veurink: intermediair & 22 \\
\hline 17 & Verdoold & Grasland & Waard/Weideveengronden & Verdoold: kwel & 21 \\
\hline 57 & Krimpenerwaard & Water & Waard/Weideveengronden & Krimpenerwaard: kwel & 21 \\
\hline 148 & Veurink & Water & Bebouwd & Veurink: intermediair & 20 \\
\hline 28 & Krimpenerwaard & Water & Waard/Weideveengronden & Krimpenerwaard: wegzijging & 20 \\
\hline 128 & Veurink & Water & Waard/Weideveengronden & Veurink: intermediair & 19 \\
\hline 126 & Krimpenerwaard & Water & Kleigronden & Krimpenerwaard: kwel & 19 \\
\hline 1 & Verdoold & Bebouwd & Waard/Weideveengronden & Verdoold: wegzijging & 18 \\
\hline 84 & Krimpenerwaard & Natuurgrasland & Waard/Weideveengronden & Krimpenerwaard: kwel & 18 \\
\hline 15 & Verdoold & Natuurgrasland & Kleigronden & Verdoold: wegzijging & 17 \\
\hline 124 & Veurink & Water & Waard/Weideveengronden & Veurink: wegzijging & 17 \\
\hline 135 & Krimpenerwaard & Grasland & Kleigronden & Niet toebedeeld & 17 \\
\hline 9 & Verdoold & Grasland & Bebouwd & Verdoold: wegzijging & 16 \\
\hline 2 & Verdoold & Water & Waard/Weideveengronden & Verdoold: wegzijging & 16 \\
\hline 91 & Krimpenerwaard & Water & Koopveengronden & Krimpenerwaard: kwel & 16 \\
\hline 64 & Verdoold & Bebouwd & Koopveengronden & Verdoold: wegzijging & 16 \\
\hline 13 & Verdoold & Water & Kleigronden & Verdoold: wegzijging & 15 \\
\hline 181 & Veurink & Grasland & Kleigronden & Niet toebedeeld & 15 \\
\hline 16 & Verdoold & Bebouwd & Waard/Weideveengronden & Verdoold: intermediair & 15 \\
\hline 177 & Veurink & Grasland & Bebouwd & Veurink: kwel & 15 \\
\hline 118 & Veurink & Water & Bebouwd & Veurink: wegzijging & 15 \\
\hline 169 & Veurink & Water & Bebouwd & Veurink: kwel & 14 \\
\hline 134 & Veurink & Water & Koopveengronden & Veurink: wegzijging & 12 \\
\hline 115 & Veurink & Grasland & Bebouwd & Veurink: wegzijging & 12 \\
\hline 117 & Veurink & Water & Kleigronden & Veurink: wegzijging & 11 \\
\hline 23 & Verdoold & Water & Waard/Weideveengronden & Verdoold: kwel & 11 \\
\hline 20 & Verdoold & Bebouwd & Waard/Weideveengronden & Verdoold: kwel & 10 \\
\hline 59 & Krimpenerwaard & Bebouwd & Kleigronden & Krimpenerwaard: intermediair & 10 \\
\hline 24 & Krimpenerwaard & Bebouwd & Bebouwd & Krimpenerwaard: wegzijging & 9,3 \\
\hline 8 & Verdoold & Natuurgrasland & Waard/Weideveengronden & Verdoold: intermediair & 8,1 \\
\hline 65 & Krimpenerwaard & Water & Kleigronden & Krimpenerwaard: wegzijging & 7,8 \\
\hline 161 & Veurink & Bebouwd & Koopveengronden & Veurink: kwel & 7,7 \\
\hline 149 & Veurink & Grasland & Bebouwd & Veurink: intermediair & 7,4 \\
\hline 175 & Veurink & Natuurgrasland & Bebouwd & Veurink: intermediair & 7,1 \\
\hline 54 & Krimpenerwaard & Water & Bebouwd & Krimpenerwaard: kwel & 7,1 \\
\hline 25 & Verdoold & Bebouwd & Bebouwd & Niet toebedeeld & 6,9 \\
\hline
\end{tabular}




\begin{tabular}{|c|c|c|c|c|c|}
\hline ID & Meteogebied & Grondgebruik & Bodemtype & Kwelklasse & ha \\
\hline 125 & Veurink & Natuurgrasland & Waard/Weideveengronden & Veurink: wegzijging & 6,4 \\
\hline 162 & Veurink & Water & Kleigronden & Veurink: intermediair & 5,8 \\
\hline 32 & Krimpenerwaard & Grasland & Bebouwd & Krimpenerwaard: intermediair & 5,6 \\
\hline 66 & Verdoold & Grasland & Kleigronden & Niet toebedeeld & 5,3 \\
\hline 152 & Veurink & Natuurgrasland & Bebouwd & Veurink: wegzijging & 5,2 \\
\hline 5 & Verdoold & Water & Waard/Weideveengronden & Verdoold: intermediair & 5,0 \\
\hline 100 & Krimpenerwaard & Water & Koopveengronden & Krimpenerwaard: wegzijging & 4,9 \\
\hline 93 & Krimpenerwaard & Natuurgrasland & Koopveengronden & Krimpenerwaard: kwel & 4,8 \\
\hline 10 & Verdoold & Water & Bebouwd & Verdoold: wegzijging & 4,6 \\
\hline 107 & Krimpenerwaard & Bebouwd & Koopveengronden & Krimpenerwaard: wegzijging & 4,6 \\
\hline 120 & Krimpenerwaard & Bebouwd & Koopveengronden & Krimpenerwaard: kwel & 4,4 \\
\hline 102 & Verdoold & Bebouwd & Bebouwd & Verdoold: intermediair & 4,0 \\
\hline 30 & Krimpenerwaard & Grasland & Bebouwd & Krimpenerwaard: wegzijging & 3,7 \\
\hline 106 & Krimpenerwaard & Natuurgrasland & Waard/Weideveengronden & Krimpenerwaard: wegzijging & 3,7 \\
\hline 78 & Verdoold & Water & Bebouwd & Verdoold: kwel & 3,6 \\
\hline 146 & Krimpenerwaard & Bebouwd & Waard/Weideveengronden & Niet toebedeeld & 3,6 \\
\hline 190 & Veurink & Water & Water & Veurink: kwel & 3,6 \\
\hline 39 & Verdoold & Grasland & Bebouwd & Niet toebedeeld & 3,5 \\
\hline 133 & Krimpenerwaard & Bebouwd & Bebouwd & Niet toebedeeld & 3,4 \\
\hline 171 & Veurink & Bebouwd & Bebouwd & Niet toebedeeld & 2,8 \\
\hline 182 & Veurink & Natuurgrasland & Kleigronden & Veurink: intermediair & 2,8 \\
\hline 40 & Verdoold & Natuurgrasland & Waard/Weideveengronden & Verdoold: kwel & 2,4 \\
\hline 179 & Veurink & Grasland & Waard/Weideveengronden & Niet toebedeeld & 2,3 \\
\hline 69 & Krimpenerwaard & Grasland & Water & Krimpenerwaard: wegzijging & 2,3 \\
\hline 121 & Veurink & Natuurgrasland & Kleigronden & Veurink: wegzijging & 2,3 \\
\hline 186 & Veurink & Grasland & Bebouwd & Niet toebedeeld & 2,0 \\
\hline 189 & Veurink & Bebouwd & Kleigronden & Niet toebedeeld & 1,8 \\
\hline 14 & Verdoold & Bebouwd & Kleigronden & Verdoold: intermediair & 1,8 \\
\hline 187 & Veurink & Natuurgrasland & Bebouwd & Veurink: kwel & 1,7 \\
\hline 94 & Verdoold & Grasland & Bebouwd & Verdoold: kwel & 1,6 \\
\hline 183 & Veurink & Water & Kleigronden & Niet toebedeeld & 1,6 \\
\hline 26 & Verdoold & Natuurgrasland & Bebouwd & Verdoold: wegzijging & 1,4 \\
\hline 19 & Verdoold & Grasland & Kleigronden & Verdoold: intermediair & 1,4 \\
\hline 127 & Krimpenerwaard & Natuurgrasland & Kleigronden & Krimpenerwaard: wegzijging & 1,4 \\
\hline 35 & Krimpenerwaard & Water & Bebouwd & Krimpenerwaard: intermediair & 1,3 \\
\hline 18 & Verdoold & Water & Kleigronden & Verdoold: intermediair & 1,3 \\
\hline 42 & Krimpenerwaard & Bebouwd & Water & Krimpenerwaard: wegzijging & 1,3 \\
\hline 68 & Krimpenerwaard & Water & Water & Krimpenerwaard: wegzijging & 1,2 \\
\hline 67 & Verdoold & Bebouwd & Kleigronden & Niet toebedeeld & 1,1 \\
\hline 139 & Krimpenerwaard & Bebouwd & Kleigronden & Niet toebedeeld & 1,1 \\
\hline 88 & Verdoold & Natuurgrasland & Kleigronden & Niet toebedeeld & 0,9 \\
\hline 180 & Veurink & Natuurgrasland & Kleigronden & Niet toebedeeld & 0,9 \\
\hline 136 & Krimpenerwaard & Water & Kleigronden & Niet toebedeeld & 0,9 \\
\hline 86 & Krimpenerwaard & Grasland & Waard/Weideveengronden & Niet toebedeeld & 0,8 \\
\hline 130 & Krimpenerwaard & Grasland & Bebouwd & Niet toebedeeld & 0,7 \\
\hline 79 & Verdoold & Water & Bebouwd & Niet toebedeeld & 0,6 \\
\hline 103 & Verdoold & Grasland & Bebouwd & Verdoold: intermediair & 0,6 \\
\hline 61 & Verdoold & Water & Kleigronden & Verdoold: kwel & 0,6 \\
\hline 36 & Krimpenerwaard & Water & Bebouwd & Krimpenerwaard: wegzijging & 0,6 \\
\hline 131 & Krimpenerwaard & Water & Bebouwd & Niet toebedeeld & 0,6 \\
\hline 80 & Verdoold & Water & Bebouwd & Verdoold: intermediair & 0,6 \\
\hline 58 & Krimpenerwaard & Water & Kleigronden & Krimpenerwaard: intermediair & 0,6 \\
\hline 87 & Krimpenerwaard & Water & Waard/Weideveengronden & Niet toebedeeld & 0,5 \\
\hline 21 & Verdoold & grasland & Water & Verdoold: wegzijging & 0,5 \\
\hline 104 & Verdoold & Natuurgrasland & Koopveengronden & Niet toebedeeld & 0,38 \\
\hline 22 & Verdoold & Water & Water & Verdoold: wegzijging & 0,38 \\
\hline 71 & Krimpenerwaard & Grasland & Water & Krimpenerwaard: intermediair & 0,38 \\
\hline 85 & Verdoold & Natuurgrasland & Bebouwd & Niet toebedeeld & 0,31 \\
\hline
\end{tabular}




\begin{tabular}{|c|c|c|c|c|c|}
\hline ID & Meteogebied & Grondgebruik & Bodemtype & Kwelklasse & ha \\
\hline 157 & Krimpenerwaard & Natuurgrasland & Kleigronden & Krimpenerwaard: intermediair & 0,31 \\
\hline 185 & Veurink & Water & Waard/Weideveengronden & Niet toebedeeld & 0,25 \\
\hline 113 & Verdoold & Natuurgrasland & Kleigronden & Verdoold: intermediair & 0,25 \\
\hline 144 & Krimpenerwaard & Natuurgrasland & Bebouwd & Krimpenerwaard: intermediair & 0,25 \\
\hline 98 & Krimpenerwaard & Bebouwd & Water & Krimpenerwaard: intermediair & 0,25 \\
\hline 145 & Krimpenerwaard & Natuurgrasland & Bebouwd & Krimpenerwaard: kwel & 0,25 \\
\hline 163 & Krimpenerwaard & Natuurgrasland & Kleigronden & Niet toebedeeld & 0,19 \\
\hline 178 & Veurink & Natuurgrasland & Waard/Weideveengronden & Niet toebedeeld & 0,19 \\
\hline 108 & Verdoold & Bebouwd & Water & Verdoold: wegzijging & 0,19 \\
\hline 55 & Verdoold & Grasland & Kleigronden & Verdoold: kwel & 0,19 \\
\hline 101 & Krimpenerwaard & Bebouwd & Water & Krimpenerwaard: kwel & 0,19 \\
\hline 105 & Verdoold & Grasland & Koopveengronden & Niet toebedeeld & 0,13 \\
\hline 143 & Krimpenerwaard & Grasland & Koopveengronden & Niet toebedeeld & 0,13 \\
\hline 38 & Verdoold & Grasland & Water & Niet toebedeeld & 0,13 \\
\hline 89 & Verdoold & Bebouwd & Waard/Weideveengronden & Niet toebedeeld & 0,13 \\
\hline 142 & Krimpenerwaard & Water & Koopveengronden & Niet toebedeeld & 0,13 \\
\hline 90 & Verdoold & Natuurgrasland & Waard/Weideveengronden & Niet toebedeeld & 0,06 \\
\hline 150 & Krimpenerwaard & Bebouwd & Koopveengronden & Niet toebedeeld & 0,06 \\
\hline 188 & Veurink & Bebouwd & Waard/Weideveengronden & Niet toebedeeld & 0,06 \\
\hline 96 & Verdoold & Water & Kleigronden & Niet toebedeeld & 0,06 \\
\hline 51 & Verdoold & Water & Water & Niet toebedeeld & 0,06 \\
\hline 81 & Verdoold & Natuurgrasland & Bebouwd & Verdoold: intermediair & 0,06 \\
\hline 77 & Verdoold & Natuurgrasland & Kleigronden & Verdoold: kwel & 0,06 \\
\hline 97 & Krimpenerwaard & Natuurgrasland & Water & Krimpenerwaard: wegzijging & 0,06 \\
\hline 70 & Krimpenerwaard & Water & Water & Krimpenerwaard: intermediair & 0,06 \\
\hline \multirow[t]{2}{*}{191} & Veurink & Natuurgrasland & Water & Veurink: kwel & 0,06 \\
\hline & & & & Totaal & 13.435 \\
\hline
\end{tabular}

\section{Tabel B1.2}

Geselecteerde rekenplots met de arealen grasland en natuurgrasland

\begin{tabular}{|c|c|c|c|c|c|c|c|c|}
\hline \multicolumn{3}{|l|}{ plotnummer } & \multicolumn{3}{|c|}{ Grasland (Iandbouw) } & \multicolumn{3}{|c|}{ natuurgrasland } \\
\hline & Nesse & Veurink & Krimpenerwaard & Verdoold & Nesse & Veurink & Krimpenerwaard & Verdoold \\
\hline 3 & 76 & 0,2 & & 236 & 19 & 0,1 & & 36 \\
\hline 12 & 149 & 0,3 & & 159 & 3 & & & 16 \\
\hline 29 & & & 413 & & & & 4 & \\
\hline 3 & & & 421 & 0,1 & & & 26 & \\
\hline 41 & 28 & & & 767 & 61 & & & 285 \\
\hline 45 & 41 & & & 1.328 & 78 & 0,2 & & 212 \\
\hline 50 & 15 & 1 & 5 & 1.288 & 15 & 1 & 0,4 & 84 \\
\hline 63 & & & 210 & & & & 2 & \\
\hline 73 & & & 399 & 1 & & 0,2 & 44 & 0,4 \\
\hline 82 & & & 184 & & & & 18 & \\
\hline 99 & & & 260 & & & & 56 & \\
\hline 109 & & & 346 & & & & 47 & \\
\hline 116 & & 210 & & 0,1 & & 3 & & \\
\hline 123 & & 320 & & & & 7 & & \\
\hline 129 & & 474 & & & & 75 & & \\
\hline 138 & & 580 & & 0,3 & & 120 & & \\
\hline 155 & & 166 & & & & 22 & & \\
\hline 159 & & 151 & 0,4 & & & 41 & & \\
\hline 164 & & 100 & & & & 3 & & \\
\hline 165 & & 372 & & & & 57 & 0,4 & \\
\hline 174 & & 333 & & & & 30 & 0,4 & \\
\hline
\end{tabular}


Tabel B1.3

Geselecteerde rekenplots (> $100 \mathrm{ha}$ ) en bijbehorende rekenparameters

\begin{tabular}{|c|c|c|c|c|c|c|c|c|}
\hline \multirow[t]{2}{*}{ ID } & \multirow[t]{2}{*}{ Kwel } & \multirow[t]{2}{*}{$\mathrm{Ha}$} & \multirow{2}{*}{$\begin{array}{l}\text { AHN3 } \\
\text { m NAP }\end{array}$} & \multirow{2}{*}{$\begin{array}{l}\text { Droog- } \\
\text { legging } \\
m-m v\end{array}$} & \multicolumn{2}{|c|}{ Stijghoogte } & \multicolumn{2}{|c|}{$\begin{array}{l}\text { Weerstand deklaag } \\
\text { (klei) }\end{array}$} \\
\hline & & & & & cm NAP & $m-m v$ & Dagen ${ }^{1)}$ & Dagen $^{2)}$ \\
\hline 46 & Verdoold: intermediair & 290 & $-1,99$ & 0,30 & -316 & 116 & 2.326 & 1.911 \\
\hline 141 & Veurink: intermediair & 120 & $-1,78$ & 0,42 & -232 & 55 & 2.223 & 2.024 \\
\hline 50 & Verdoold: kwel & 1.310 & $-1,79$ & 0,44 & -230 & 51 & 1.429 & 1.240 \\
\hline 41 & Verdoold: wegzijging & 795 & $-1,91$ & 0,41 & -354 & 163 & 1.624 & 738 \\
\hline 138 & Veurink: intermediair & 580 & $-1,72$ & 0,45 & -221 & 49 & 1.889 & 1.499 \\
\hline 129 & Veurink: wegzijging & 474 & $-1,82$ & 0,42 & -253 & 71 & 2.553 & 2.163 \\
\hline 174 & Veurink: kwel & 333 & $-1,53$ & 0,58 & -146 & -7 & 1.339 & 1.182 \\
\hline 123 & Veurink: wegzijging & 317 & $-1,80$ & 0,45 & -275 & 96 & 2.485 & 2.181 \\
\hline 73 & Krimpenerwaard: intermediair & 308 & $-1,54$ & 0,42 & -190 & 36 & 1.168 & 1.072 \\
\hline 12 & Verdoold: wegzijging & 302 & $-2,04$ & 0,55 & -435 & 231 & 1.764 & 615 \\
\hline 109 & Krimpenerwaard: kwel & 298 & $-1,18$ & 0,66 & -146 & 28 & 840 & 598 \\
\hline 99 & Krimpenerwaard: wegzijging & 260 & $-1,47$ & 0,42 & -202 & 55 & 992 & 793 \\
\hline 3 & Verdoold: wegzijging & 208 & $-2,03$ & 0,44 & -399 & 196 & 1.789 & 779 \\
\hline 116 & Veurink: wegzijging & 195 & $-1,74$ & 0,51 & -301 & 127 & 2.303 & 1.902 \\
\hline 63 & Krimpenerwaard: wegzijging & 194 & $-1,37$ & 0,50 & -190 & 53 & 714 & 592 \\
\hline
\end{tabular}

1) gemiddelde weerstand (afgeleid uit grondwatermodel)

2) $1 /$ recispoke gemiddelde waarde. Met deze methode tellen cellen met een heel lage waarde (bijvoorbeeld bij gaten in de afdekkende klei) minder zwaar mee. 


\section{Bijlage 2 Methodiek retentie}

\section{Poldersystemen}

De retentie van stikstof en fosfor in het oppervlaktewater varieert per polder en is afhankelijk van de onderliggende retentieprocessen. De grootte van deze retentieprocessen is afgeleid uit metingen in het oppervlaktewater (PLONS). Op deze manier is de capaciteit van het oppervlaktewatersysteem bepaald om stikstof vast te leggen, uitgedrukt in gram per $\mathrm{m}^{2}$ waterbodem. De zo berekende absolute $\mathrm{N}$-retentie heeft betrekking op alle nutriëntenbronnen in de polder. De volgende retentieprocessen zijn gekwantificeerd:

- Denitrificatie

- Netto opname (zomerhalfjaar) en afgifte (winterhalfjaar) van nutriënten door waterplanten

Dit is gedaan voor het zomer- en winterhalfjaar voor polders die vooral uit veen of klei bestaan. Voor de zandpolders (Noord-Nederland) waren onvoldoende metingen beschikbaar om de retentieprocessen te kwantificeren. Het retentieproces sedimentatie is niet expliciet meegenomen, al zit dit proces deels verwerkt in de waterplantensterfte die een groot aandeel heeft in de totale sedimentatie.

\section{Denitrificatie}

Voor het PLONS-project (www.plons.wur.nl) is in een aantal sloten verspreid over Nederland de denitrificatie gemeten. De gemeten denitrificatiesnelheden in poldersloten en de watertemperatuur tijdens het meten, ingedeeld naar het bodemtype klei of veen, zijn weergegeven in Tabel B2.1 (Veraart et al., in voorbereiding). Deze denitrificatiesnelheden zijn omgezet naar een gemiddelde denitrificatiesnelheid in het zomer- en het winterhalfjaar, door aan te nemen dat de denitrificatiesnelheid $(D)$ afhangt van de watertemperatuur $(T)$ volgens een aangepaste Arrheniusvergelijking:

$$
D_{T}=D_{20} \cdot \theta_{S}^{(T-20)}
$$

Waarin $D_{20}$ de denitrificatiesnelheid is bij $20^{\circ} \mathrm{C}$ en $\theta_{s}$ de temperatuurcoëfficiënt die de waarde 1,07 is toegekend; een waarde die kenmerkend is voor veel biochemische reacties. Echter zijn voor de denitrificatie ook hogere waarden voor de temperatuurcoëfficiënt gevonden van 1,24 en 1,28 (Veraart et al., 2011b).

Met formule 3 zijn maandgemiddelde denitrificatiesnelheden berekend voor de klei- en veenpolders, uitgaande van maandgemiddelde luchttemperaturen gemeten in de Bilt in de jaren 1990-2009 (data KNMI). De maandgemiddelde denitrificatiesnelheden zijn opgeschaald naar zomer- en winterhalfjaargemiddelden (Tabel B2.2).

\section{Tabel B2.1}

Gemeten denitrificatiesnelheden in veen- en kleigebieden $\left(\left(\mu \mathrm{mol} \mathrm{N} \mathrm{m}^{-2} \mathrm{~h}^{-1}\right)\right.$ en de watertemperatuur $\left({ }^{\circ} \mathrm{C}\right)$ op het moment van meten (Veraart et al., in voorbereiding). $n=a a n t a l$ waarnemingen, std $=$ standaarddeviatie

\begin{tabular}{lllllll} 
Bodemtype & $n$ & \multicolumn{2}{c}{ Denitrificatie } & \multicolumn{3}{c}{ Temperatuur } \\
\cline { 3 - 7 } & & Gemiddeld & Minimum & Maximum & Gemiddeld & Std. \\
Klei & 4 & 180,2 & 31,0 & 496,8 & 16,8 & 0,9 \\
\hline Veen & 7 & 62,9 & 5,9 & 166,6 & 21,3 & 0,8 \\
\hline
\end{tabular}


Tabel B2.2

Afgeleide denitrificatiesnelheden $\left(\mathrm{g} \mathrm{N} \mathrm{m}^{-2}\right)$ voor klei- en veenpolders, voor winter- en zomerhalfjaar

\begin{tabular}{lll}
\multirow{2}{*}{ Bodemtype } & Denitrificatie & Winterhalifjaar \\
\cline { 2 - 3 } Klei & Zomerhalfiaar & 5,3 \\
\hline Veen & 9,9 & 1,4 \\
\hline
\end{tabular}

\section{Waterplanten en stikstof}

Uit verschillende databronnen is een inschatting gemaakt van de hoeveelheid waterplanten aan het einde van het groeiseizoen, gemiddeld over de klei- en veenpolders (Tabel B2.3). Om een inschatting te kunnen maken van de stikstof die gemoeid is met de groei en sterfte van waterplanten, is geschat welk deel van de biomassa 'overwintert'. Modelresultaten van het oppervlaktewaterkwaliteitsmodel Nuswalite (Siderius et al., 2008) geven aan dat ongeveer $20 \%$ van de kroosbiomassa overwintert en ongeveer $25 \%$ van de waterpest en ondergedoken waterplanten overwintert.

\section{Tabel B2.3}

Gemiddelde hoeveelheid waterplanten ( $g$ droge stof $m^{-2}$ ) aan het einde van het groeiseizoen, volgend uit verschillende databronnen

\begin{tabular}{llll} 
& Wodemtype & & \\
\cline { 2 - 3 } & Waterplanten & Kroos & Ondergedoken \\
Klei & 8 & 43 & 12 \\
\hline Veen & 29 & 14 & 25 \\
\hline
\end{tabular}

Tabel B2.4 geeft een overzicht van de geschatte hoeveelheid stikstof die gemoeid is bij de groei en sterfte van waterplanten, aangenomen dat:

- kroosbiomassa voor $4 \%$ uit $\mathrm{N}$ bestaat (Roijackers et al., 2004);

- ondergedoken waterplanten en waterpest voor 3,5\% uit $\mathrm{N}$ bestaan (Muhammetoglu et al., 2000);

- de waterlopen aan het einde van de zomer worden gemaaid, waardoor $80 \%$ van de waterplanten wordt verwijderd. De overgebleven $20 \%$ draagt bij aan de nalevering van $\mathrm{N}$ naar de waterkolom door sterfte.

\section{Tabel B2.4}

Hoeveelheid $N$ (in $\mathrm{g} \mathrm{N} \mathrm{m}^{-2}$ ) die naar schatting is gemoeid bij de nettogroei (zomerhalfjaar) en nettosterfte (winterhalfjaar) van waterplanten in klei- en veenpolders. NB Er is aangenomen dat $80 \%$ van de waterplanten in de waterlopen aan het einde van de zomer wordt gemaaid; deze planten sterven niet meer af in de waterlopen, waardoor alleen de resterende $20 \%$ van de waterplanten bijdraagt aan de nalevering van $N$ door sterfte

\begin{tabular}{lll} 
Bodemtype & Groei & Sterite \\
Klei & 1,92 & 0,38 \\
\hline Veen & 1,85 & 0,37 \\
\hline
\end{tabular}

\section{Totale stikstofretentie}

Tabel B2.5 geeft de geschatte hoeveelheid stikstofretentie in de klei- en veenpolders; het opgetelde effect van denitrificatie en waterplanten. Deze hoeveelheden, in gram per $\mathrm{m}^{2}$ waterbodem, zijn vertaald naar hoeveelheden per polder door vermenigvuldiging met het areaal aan open water volgens het NHI (www.nhi.nu). Het is de vraag of het openwateroppervlak een goede benadering geeft van het oppervlak waarover stikstofretentie plaatsvindt. 
De gehele natte omtrek - waterbodem en talud - draagt waarschijnlijk bij aan de stikstofretentie, al zal het talud per strekkende meter waarschijnlijk in mindere mate bijdragen. Daarom is het openwateroppervlak bij benadering een goede maat voor het effectieve retentieoppervlak.

\section{Tabel B2.5}

Geschatte hoeveelheid stikstofretentie (in $\mathrm{g} \mathrm{N} \mathrm{m}^{-2}$ ) in klei- en veenpolders

\begin{tabular}{lll} 
Bodemtype & Zomerhalijaar & Winterhalfijaar \\
Klei & 1,92 & 0,38 \\
\hline Veen & 1,85 & 0,37
\end{tabular}




\section{Bijlage 3 Waterbalansen}
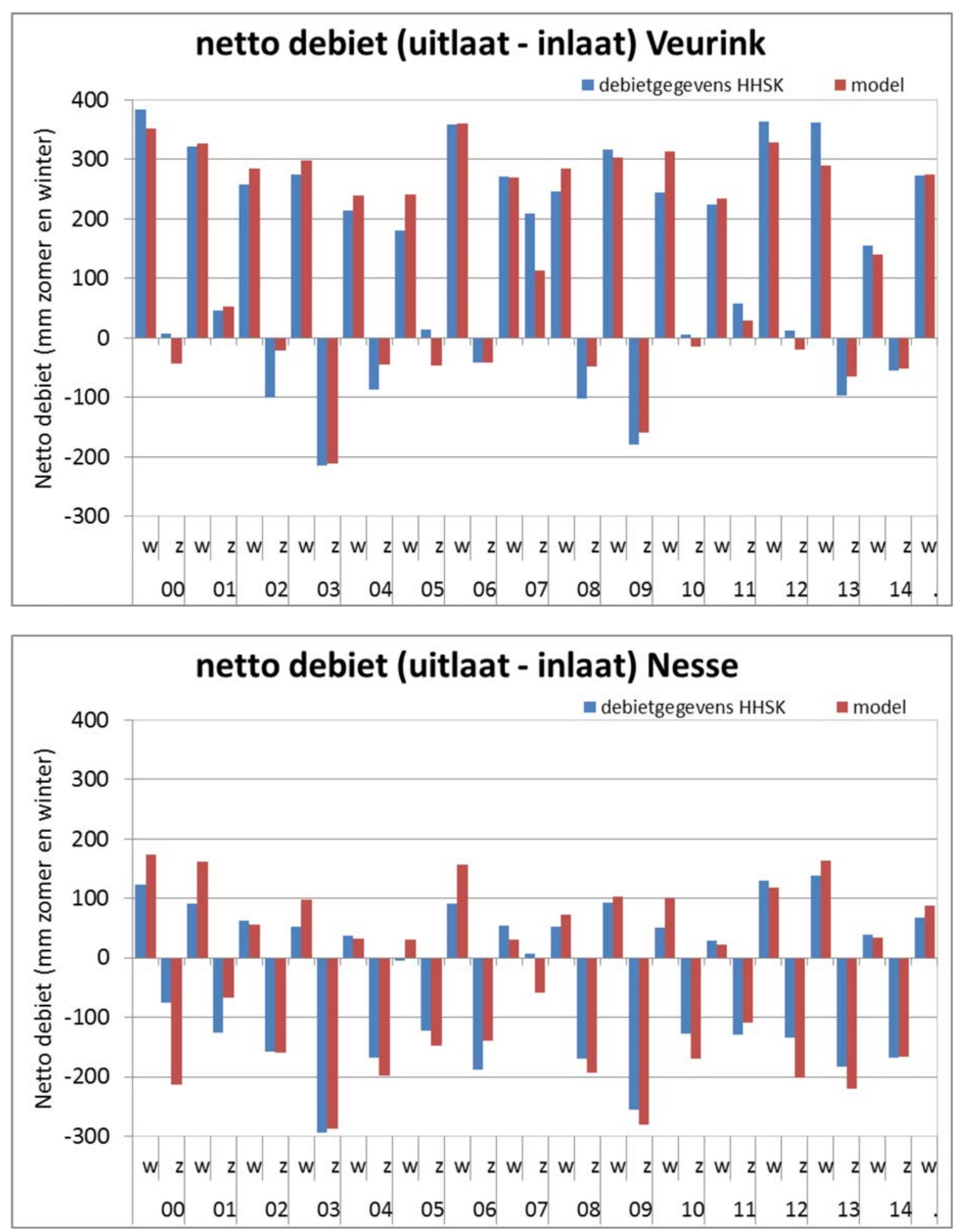

Figuur B3.1 Berekende en uit metingen afgeleide water in- en uitlaat in het zomer- en winterhalfjaar in de periode $2000-2014$ 

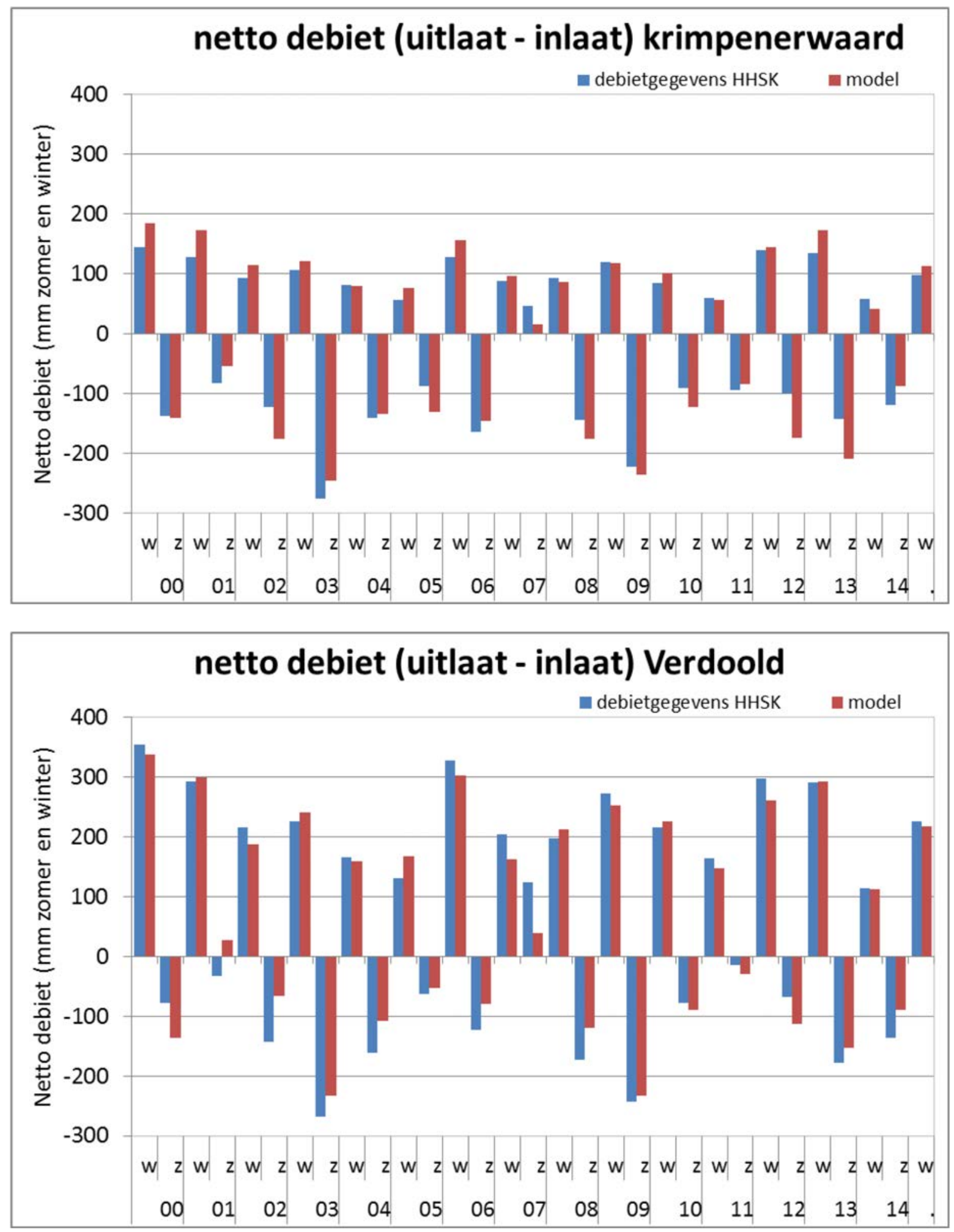

Figuur B3.1 Berekende en uit metingen afgeleide water in- en uitlaat in het zomer- en winterhalfjaar in de periode 2000-2014 


\section{Bijlage 4 Uit- en afspoeling nutriënten}
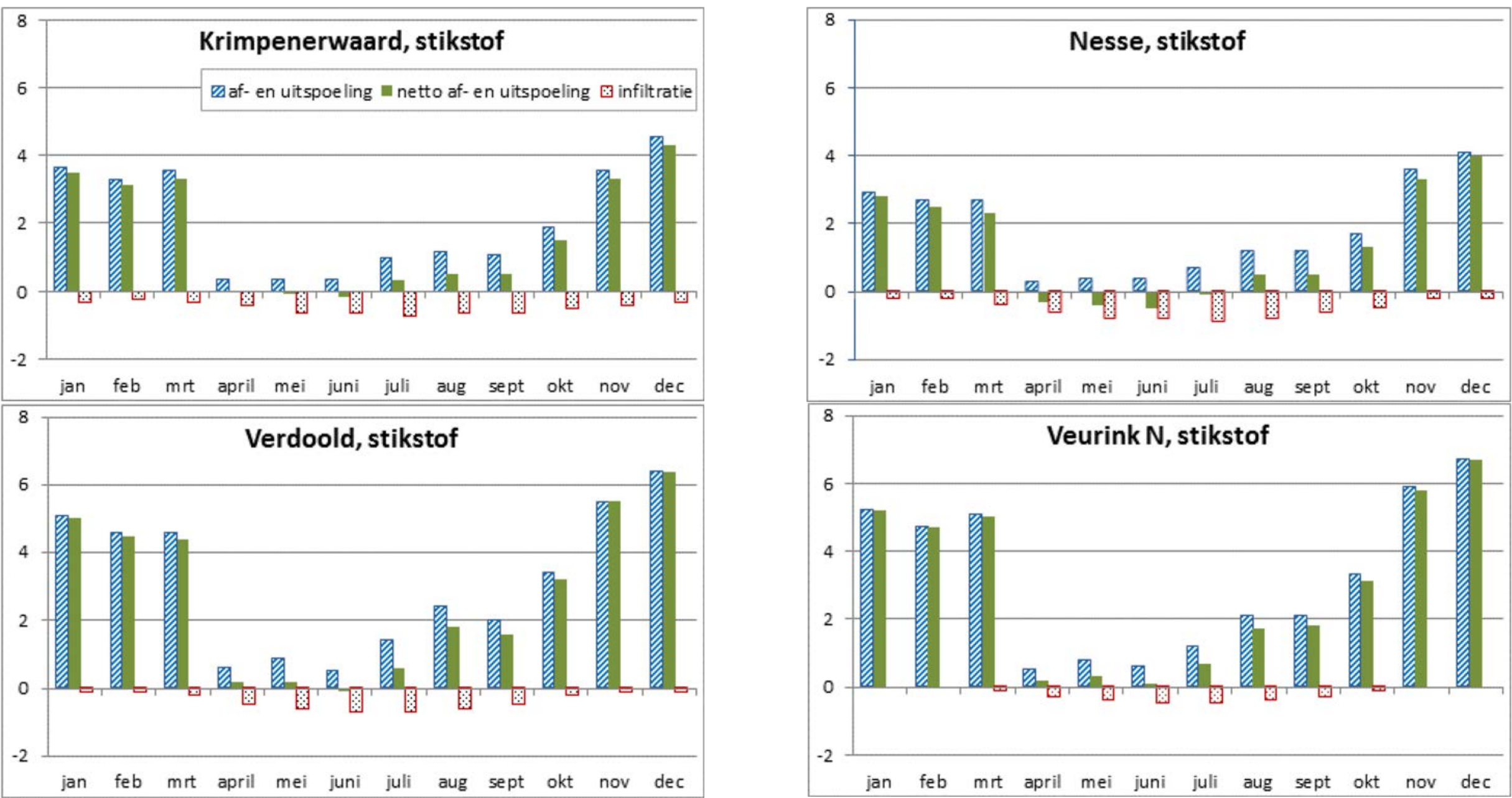

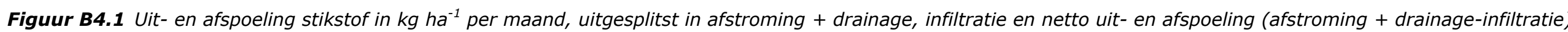



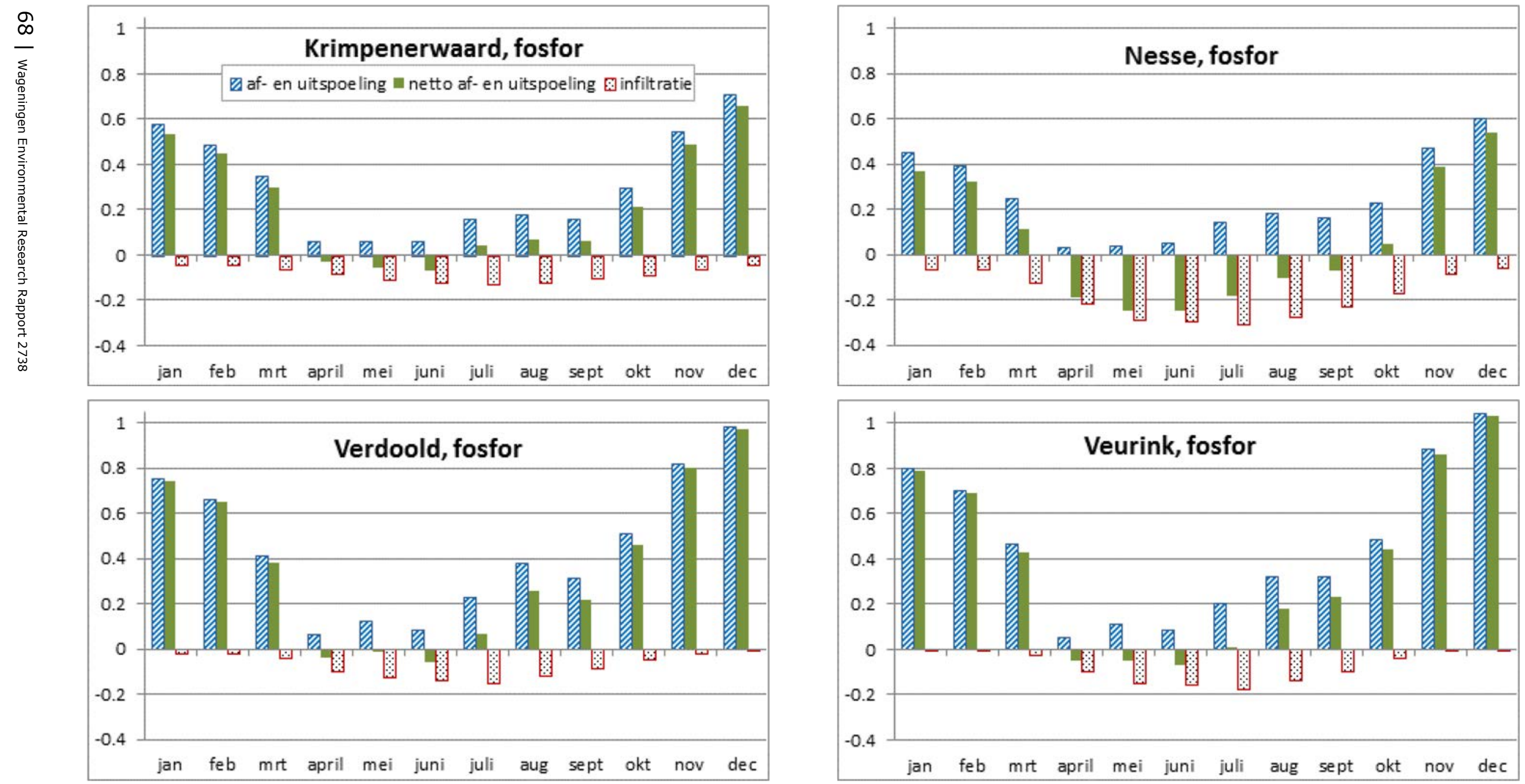

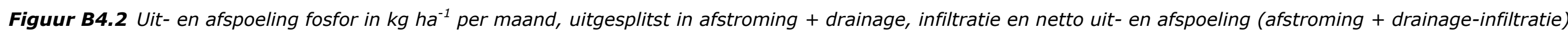



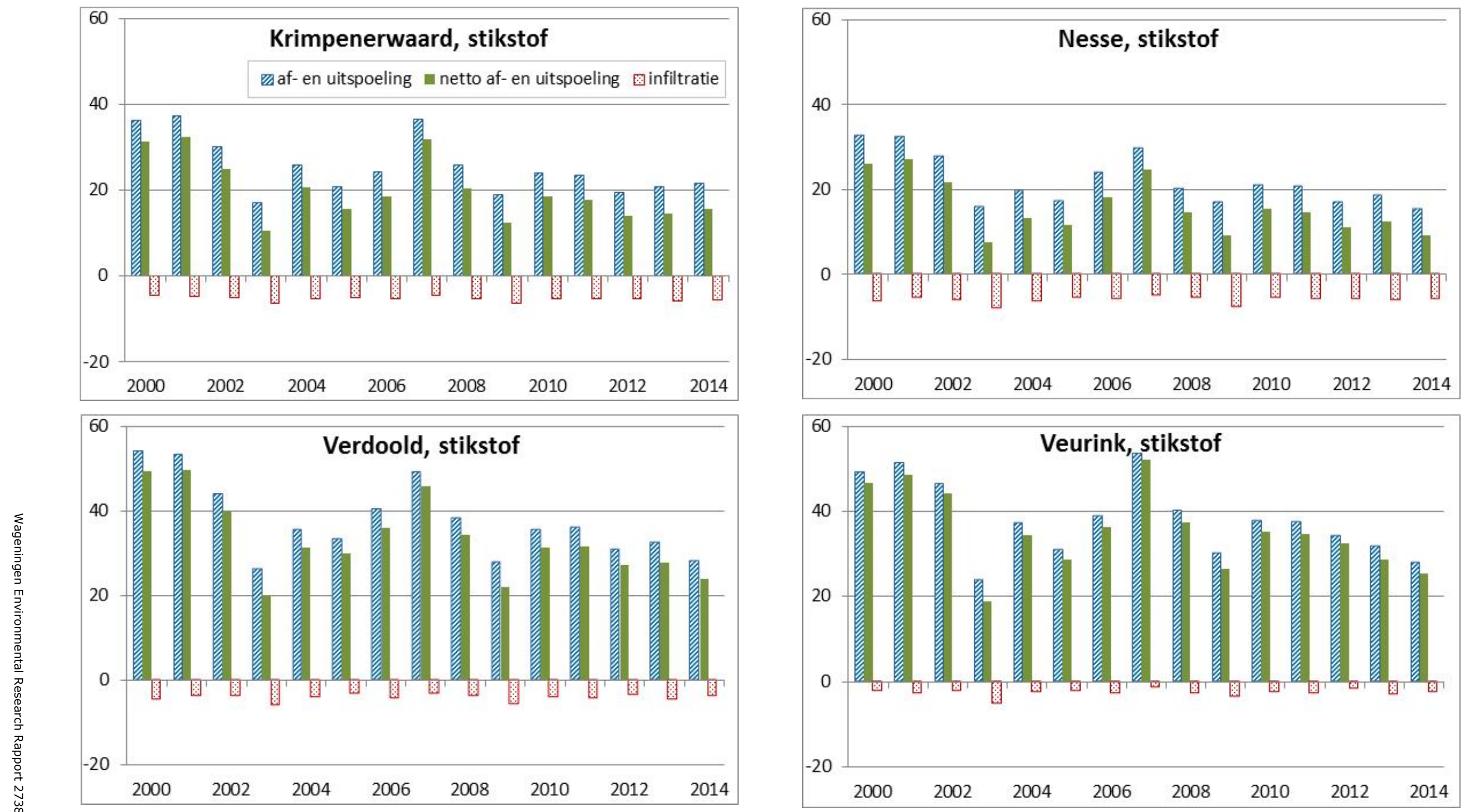

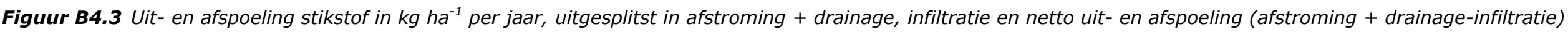



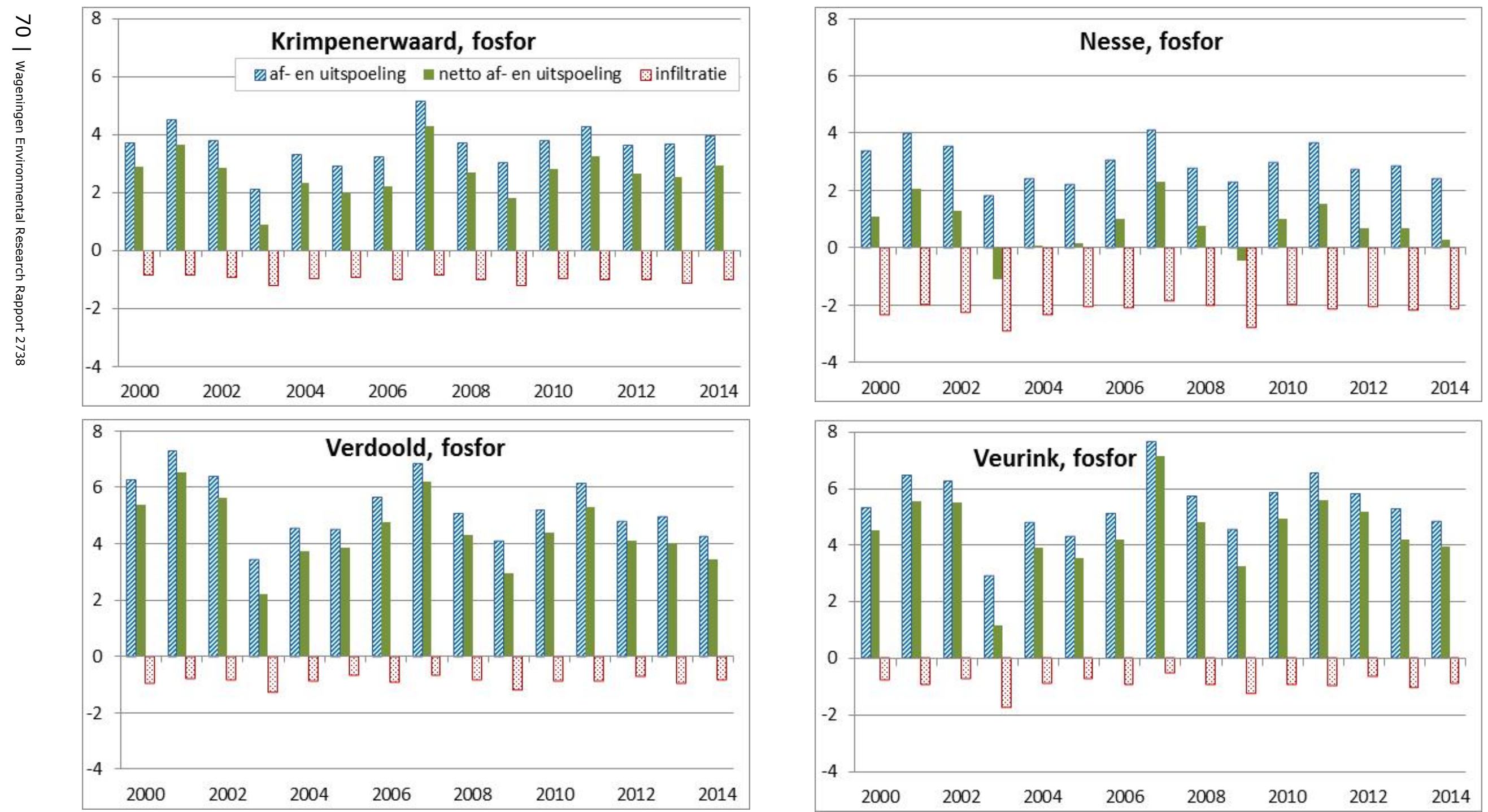

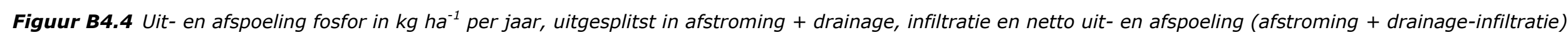




\section{Bijlage 5 Nutriëntenbalansen}

Tabel B5.1

Stikstof-en fosforbalans voor de periode 2000-2014 voor deelgebied Veurink

\begin{tabular}{|c|c|c|c|c|c|c|c|c|c|c|c|c|c|c|c|c|}
\hline Stikstof & 2000 & 2001 & 2002 & 2003 & 2004 & 2005 & 2006 & 2007 & 2008 & 2009 & 2010 & 2011 & 2012 & 2013 & 2014 & gemiddeld \\
\hline Uit- en afspoeling landbouw & 115 & 119 & 108 & 43,4 & 84,2 & 70,1 & 86,6 & 129 & 92,2 & 62,4 & 85,0 & 84,2 & 77,5 & 67,6 & 61,0 & 85,7 \\
\hline Uit- en afspoeling natuur & 17,1 & 18,6 & 16,7 & 9,9 & 13,0 & 10,9 & 15,6 & 18,6 & 13,7 & 12,3 & 14,4 & 13,7 & 14,2 & 13,1 & 10,5 & 14,2 \\
\hline Overige landbouwemissies & 5,3 & 3,2 & 3,2 & 3,1 & 3,4 & 4,2 & 2,6 & 3,3 & 1,1 & 1,1 & 3,3 & 3,5 & 3,0 & 3,0 & 3,0 & 3,1 \\
\hline Atmosferische depositie & 19,5 & 11,6 & 4,7 & 4,7 & 12,0 & 18,3 & 17,9 & 17,7 & 16,8 & 16,7 & 17,0 & 16,7 & 16,4 & 16,4 & 16,4 & 14,8 \\
\hline Rwzi & - & - & - & - & - & - & - & - & - & - & - & - & - & - & - & - \\
\hline Industriële lozingen & 0,19 & 0,02 & 0,00 & 0,02 & 0,48 & 0,16 & 0,34 & 0,39 & 0,00 & 0,00 & 0,00 & 0,00 & 0,00 & 0,00 & 0,00 & 0,11 \\
\hline Overige emissies & 3,1 & 4,5 & 4,2 & 3,7 & 1,3 & 1,4 & 0,92 & 0,77 & 0,62 & 0,54 & 0,73 & 0,71 & 0,77 & 0,77 & 0,77 & 1,7 \\
\hline Inlaat & 21,3 & 35,0 & 42,1 & 67,0 & 37,3 & 29,1 & 41,8 & 20,9 & 30,8 & 45,6 & 31,5 & 39,8 & 29,2 & 41,3 & 35,2 & 36,5 \\
\hline Directe kwel/wegzijging & $-1,8$ & $-2,0$ & $-2,0$ & $-1,5$ & $-1,6$ & $-1,4$ & $-1,4$ & $-1,4$ & $-1,4$ & $-1,1$ & $-1,3$ & $-1,1$ & $-1,1$ & $-1,2$ & $-1,2$ & $-1,4$ \\
\hline Uit- en afspoeling stedelijk & 2,8 & 3,5 & 3,5 & 1,7 & 2,5 & 2,5 & 2,8 & 3,8 & 2,9 & 2,2 & 3,0 & 3,4 & 3,0 & 2,9 & 2,3 & 2,8 \\
\hline Eenheden/honden/bladval & 4,1 & 4,1 & 4,1 & 4,1 & 4,1 & 4,1 & 4,1 & 4,1 & 4,1 & 4,1 & 4,1 & 4,1 & 4,1 & 4,1 & 4,1 & 4,1 \\
\hline Totaal IN & 187 & 197 & 185 & 136 & 157 & 139 & 171 & 197 & 161 & 144 & 158 & 165 & 147 & 148 & 132 & 162 \\
\hline Retentie & 94,3 & 99,6 & 93,5 & 68,8 & 79,1 & 70,4 & 86,4 & 99,1 & 81,2 & 72,5 & 79,5 & 83,1 & 74,1 & 74,6 & 66,7 & 81,5 \\
\hline Totaal UIT (berekend) & 92,5 & 97,6 & 91,5 & 67,4 & 77,5 & 68,9 & 85,0 & 97,8 & 79,8 & 71,4 & 78,3 & 82,0 & 73,0 & 73,5 & 65,5 & 80,1 \\
\hline Totaal UIT ('gemeten') & 92,6 & 112 & 114 & 77,7 & 89,6 & 65,7 & 71,6 & 99,7 & 70,4 & 73,0 & 76,8 & 84,6 & 76,0 & 87,7 & 78,2 & 84,7 \\
\hline Fosfor & 2000 & 2001 & 2002 & 2003 & 2004 & 2005 & 2006 & 2007 & 2008 & 2009 & 2010 & 2011 & 2012 & 2013 & 2014 & gemiddeld \\
\hline Uit- en afspoeling landbouw & 11,1 & 13,8 & 13,7 & 2,7 & 9,8 & 8,8 & 10,4 & 17,8 & 12,0 & 8,2 & 12,3 & 14,0 & 12,9 & 10,8 & 9,9 & 11,2 \\
\hline Uit- en afspoeling natuur & 1,7 & 1,9 & 1,9 & 0,6 & 1,3 & 1,2 & 1,5 & 2,3 & 1,6 & 1,1 & 1,7 & 1,8 & 1,7 & 1,4 & 1,2 & 1,5 \\
\hline Overige landbouwemissies & 1,2 & 0,26 & 0,29 & 0,25 & 0,28 & 0,93 & 0,19 & 0,20 & 0,04 & 0,04 & 0,76 & 0,81 & 0,67 & 0,67 & 0,67 & 0,47 \\
\hline Atmosferische depositie & - & - & - & - & - & - & - & - & - & - & - & - & - & - & - & - \\
\hline Rwzi & - & - & - & - & - & - & - & - & - & - & - & - & - & - & - & - \\
\hline Industriële lozingen & 0,07 & 0,01 & 0,01 & 0,00 & 0,07 & 0,06 & 0,04 & 0,02 & 0,01 & 0,01 & 0,01 & 0,00 & 0,00 & 0,00 & 0,00 & 0,02 \\
\hline Overige emissies & 0,43 & 0,49 & 0,69 & 0,58 & 0,13 & 0,18 & 0,11 & 0,09 & 0,06 & 0,05 & 0,08 & 0,08 & 0,09 & 0,09 & 0,09 & 0,22 \\
\hline Inlaat & 1,2 & 2,0 & 2,3 & 3,8 & 2,1 & 1,5 & 2,3 & 1,0 & 1,6 & 2,6 & 1,8 & 2,0 & 1,5 & 2,3 & 1,9 & 2,0 \\
\hline Directe kwel/wegzijging & $-0,69$ & $-0,68$ & $-0,60$ & $-0,35$ & $-0,42$ & $-0,56$ & $-0,41$ & $-0,44$ & $-0,43$ & $-0,31$ & $-0,31$ & $-0,28$ & $-0,30$ & $-0,26$ & $-0,35$ & $-0,43$ \\
\hline Uit- en afspoeling stedelijk & 0,28 & 0,35 & 0,35 & 0,17 & 0,25 & 0,25 & 0,28 & 0,38 & 0,29 & 0,22 & 0,30 & 0,34 & 0,30 & 0,29 & 0,23 & 0,28 \\
\hline Eenheden/honden/bladval & 0,87 & 0,87 & 0,87 & 0,87 & 0,87 & 0,87 & 0,87 & 0,87 & 0,87 & 0,87 & 0,87 & 0,87 & 0,87 & 0,87 & 0,87 & 0,87 \\
\hline Totaal IN & 16,1 & 19,0 & 19,5 & 8,5 & 14,3 & 13,3 & 15,3 & 22,3 & 16,1 & 12,7 & 17,4 & 19,6 & 17,8 & 15,8 & 14,6 & 16,2 \\
\hline Retentie & 7,5 & 9,0 & 9,1 & 3,1 & 6,6 & 6,1 & 7,0 & 11,0 & 7,7 & 5,7 & 8,1 & 9,1 & 8,4 & 7,1 & 6,7 & 7,5 \\
\hline Totaal UIT (berekend) & 8,5 & 10,0 & 10,5 & 5,5 & 7,7 & 7,2 & 8,2 & 11,3 & 8,3 & 7,0 & 9,3 & 10,5 & 9,4 & 8,7 & 7,9 & 8,7 \\
\hline Totaal UIT ('gemeten') & 22,3 & 25,7 & 21,7 & 13,3 & 14,4 & 17,4 & 15,8 & 24,3 & 13,9 & 13,4 & 16,7 & 18,0 & 15,5 & 16,8 & 14,9 & 17,6 \\
\hline
\end{tabular}


Tabel B5.2

Stikstof- en fosforbalans voor de periode 2000-2014 voor deelgebied Krimpenerwaard

\begin{tabular}{|c|c|c|c|c|c|c|c|c|c|c|c|c|c|c|c|c|}
\hline Stikstof & 2000 & 2001 & 2002 & 2003 & 2004 & 2005 & 2006 & 2007 & 2008 & 2009 & 2010 & 2011 & 2012 & 2013 & 2014 & gemiddeld \\
\hline Uit- en afspoeling landbouw & 62,6 & 64,3 & 49,2 & 19,7 & 40,8 & 30,6 & 35,7 & 63,3 & 40,2 & 23,0 & 36,2 & 34,7 & 26,8 & 27,6 & 30,6 & 39,0 \\
\hline Uit- en afspoeling natuur & 7,1 & 7,7 & 6,1 & 3,5 & 5,1 & 4,1 & 5,4 & 7,1 & 5,2 & 4,4 & 4,9 & 4,8 & 4,5 & 4,8 & 4,4 & 5,3 \\
\hline Overige landbouwemissies & 4,1 & 2,8 & 2,8 & 2,7 & 2,9 & 3,3 & 2,1 & 2,6 & 0,92 & 0,92 & 2,6 & 2,7 & 2,4 & 2,4 & 2,4 & 2,5 \\
\hline Atmosferische depositie & 13,9 & 11,3 & 3,6 & 3,6 & 11,3 & 13,0 & 12,7 & 12,5 & 11,9 & 11,8 & 12,1 & 11,9 & 11,7 & 11,7 & 11,7 & 10,9 \\
\hline Rwzi & 3,8 & 4,1 & 5,1 & 3,6 & 5,0 & 3,3 & 4,1 & 4,4 & 4,6 & 3,8 & 4,9 & 5,3 & 5,5 & 6,3 & 6,3 & 4,6 \\
\hline Industriële lozingen & 0,00 & 0,00 & 0,00 & 0,00 & 0,00 & 0,00 & 0,00 & 0,00 & 0,00 & 0,00 & 0,00 & 0,00 & 0,00 & 0,00 & 0,00 & 0,00 \\
\hline Overige emissies & 1,2 & 2,3 & 4,3 & 3,3 & 0,76 & 0,66 & 0,43 & 0,30 & 0,24 & 0,22 & 0,30 & 0,29 & 0,32 & 0,32 & 0,32 & 1,1 \\
\hline Inlaat & 63,7 & 81,8 & 92,0 & 119 & 78,8 & 60,2 & 89,4 & 66,2 & 73,9 & 91,9 & 71,6 & 88,4 & 70,5 & 87,1 & 74,9 & 80,6 \\
\hline Directe kwel/wegzijging & $-5,0$ & $-6,0$ & $-5,4$ & $-5,1$ & $-4,6$ & $-3,7$ & $-3,6$ & $-4,0$ & $-3,8$ & $-3,7$ & $-4,1$ & $-4,7$ & $-3,1$ & $-3,9$ & $-4,4$ & $-4,3$ \\
\hline Uit- en afspoeling stedelijk & 0,93 & 1,2 & 0,95 & 0,50 & 1,1 & 0,79 & 0,82 & 1,4 & 0,79 & 0,77 & 1,0 & 1,1 & 0,82 & 1,0 & 1,0 & 0,95 \\
\hline Eenheden/honden/bladval & 1,7 & 1,7 & 1,7 & 1,7 & 1,7 & 1,7 & 1,7 & 1,7 & 1,7 & 1,7 & 1,7 & 1,7 & 1,7 & 1,7 & 1,7 & 1,7 \\
\hline Totaal IN & 154 & 171 & 160 & 152 & 143 & 114 & 149 & 156 & 136 & 135 & 131 & 146 & 121 & 139 & 129 & 142 \\
\hline Retentie & 79,5 & 88,6 & 82,9 & 78,7 & 73,7 & 58,8 & 76,2 & 79,8 & 69,7 & 69,3 & 67,6 & 75,5 & 62,2 & 71,5 & 66,7 & 73,3 \\
\hline Totaal UIT (berekend) & 74,5 & 82,6 & 77,5 & 73,5 & 69,1 & 55,1 & 72,6 & 75,9 & 65,9 & 65,6 & 63,5 & 70,8 & 59,0 & 67,3 & 62,3 & 69,0 \\
\hline Totaal UIT ('gemeten') & 73,8 & 91,9 & 99,3 & 92,2 & 79,3 & 51,2 & 65,6 & 64,0 & 55,5 & 68,7 & 58,2 & 68,1 & 10,5 & 66,3 & 60,7 & 69,7 \\
\hline Fosfor & 2000 & 2001 & 2002 & 2003 & 2004 & 2005 & 2006 & 2007 & 2008 & 2009 & 2010 & 2011 & 2012 & 2013 & 2014 & Gemiddeld \\
\hline Uit- en afspoeling landbouw & 5,7 & 7,4 & 5,7 & 1,8 & 4,7 & 4,0 & 4,3 & 8,6 & 5,4 & 3,6 & 5,6 & 6,4 & 5,2 & 5,0 & 5,8 & 5,3 \\
\hline Uit- en afspoeling natuur & 0,69 & 0,78 & 0,62 & 0,22 & 0,53 & 0,47 & 0,56 & 0,94 & 0,65 & 0,47 & 0,68 & 0,76 & 0,64 & 0,63 & 0,70 & 0,62 \\
\hline Overige landbouwemissies & 0,92 & 0,22 & 0,25 & 0,21 & 0,24 & 0,72 & 0,16 & 0,16 & 0,03 & 0,03 & 0,59 & 0,63 & 0,52 & 0,52 & 0,52 & 0,37 \\
\hline Atmosferische depositie & - & - & - & - & - & - & - & - & - & - & - & - & - & - & - & - \\
\hline Rwzi & 0,72 & 0,61 & 1,2 & 0,95 & 1,3 & 0,88 & 1,3 & 1,6 & 1,6 & 1,5 & 1,4 & 2,3 & 1,6 & 2,3 & 2,3 & 1,4 \\
\hline Industriële lozingen & 0,00 & 0,00 & 0,00 & 0,00 & 0,00 & 0,00 & 0,00 & 0,00 & 0,00 & 0,00 & 0,00 & 0,00 & 0,00 & 0,00 & 0,00 & 0,00 \\
\hline Overige emissies & 0,17 & 0,24 & 0,43 & 0,25 & 0,08 & 0,09 & 0,05 & 0,03 & 0,02 & 0,02 & 0,03 & 0,03 & 0,04 & 0,04 & 0,04 & 0,11 \\
\hline Inlaat & 5,1 & 6,9 & 7,4 & 10,5 & 7,0 & 5,5 & 7,6 & 4,8 & 6,0 & 8,2 & 6,3 & 6,5 & 5,8 & 7,7 & 6,8 & 6,8 \\
\hline Directe kwel/wegzijging & $-0,75$ & $-0,79$ & $-0,80$ & $-0,51$ & $-0,48$ & $-0,61$ & $-0,47$ & $-0,99$ & $-0,60$ & $-0,45$ & $-0,54$ & $-0,65$ & $-0,75$ & $-0,38$ & $-0,81$ & $-0,64$ \\
\hline Uit- en afspoeling stedelijk & 0,09 & 0,12 & 0,10 & 0,05 & 0,11 & 0,08 & 0,08 & 0,14 & 0,08 & 0,08 & 0,10 & 0,11 & 0,08 & 0,10 & 0,10 & 0,09 \\
\hline Eenheden/honden/bladval & 0,36 & 0,36 & 0,36 & 0,36 & 0,36 & 0,36 & 0,36 & 0,36 & 0,36 & 0,36 & 0,36 & 0,36 & 0,36 & 0,36 & 0,36 & 0,36 \\
\hline Totaal IN & 13,0 & 15,8 & 15,3 & 13,8 & 13,9 & 11,5 & 14,0 & 15,6 & 13,6 & 13,8 & 14,5 & 16,5 & 13,6 & 16,3 & 15,8 & 14,4 \\
\hline Retentie & 4,8 & 5,9 & 5,3 & 3,6 & 4,6 & 3,9 & 4,5 & 6,3 & 4,8 & 4,2 & 5,0 & 5,7 & 4,8 & 5,2 & 5,4 & 4,9 \\
\hline Totaal UIT (berekend) & 8,2 & 9,9 & 10,0 & 10,2 & 9,3 & 7,6 & 9,5 & 9,3 & 8,8 & 9,6 & 9,5 & 10,7 & 8,8 & 11,1 & 10,4 & 9,5 \\
\hline Totaal UIT ('gemeten') & 10,3 & 13,6 & 13,5 & 14,4 & 10,1 & 8,2 & 11,2 & 12,7 & 9,4 & 11,1 & 10,4 & 10,9 & 9,2 & 11,1 & 10,6 & 11,1 \\
\hline
\end{tabular}


Tabel B5.3

Stikstof- en fosforbalans voor de periode 2000-2014 voor deelgebied Nesse

\begin{tabular}{|c|c|c|c|c|c|c|c|c|c|c|c|c|c|c|c|c|}
\hline Stikstof & 2000 & 2001 & 2002 & 2003 & 2004 & 2005 & 2006 & 2007 & 2008 & 2009 & 2010 & 2011 & 2012 & 2013 & 2014 & gemiddeld \\
\hline Uit- en afspoeling landbouw & 4,7 & 4,9 & 3,8 & 0,42 & 1,9 & 1,5 & 2,6 & 4,9 & 2,2 & 0,53 & 2,2 & 2,1 & 1,1 & 1,3 & 0,81 & 2,3 \\
\hline Uit- en afspoeling natuur & 6,5 & 6,7 & 5,5 & 2,9 & 3,7 & 3,5 & 5,2 & 5,8 & 4,1 & 3,4 & 4,5 & 4,2 & 3,7 & 4,1 & 3,2 & 4,5 \\
\hline Overige landbouwemissies & 0,57 & 0,46 & 0,46 & 0,44 & 0,47 & 0,47 & 0,39 & 0,50 & 0,13 & 0,13 & 0,30 & 0,31 & 0,28 & 0,28 & 0,28 & 0,37 \\
\hline Atmosferische depositie & 2,4 & 1,3 & 0,51 & 0,51 & 1,3 & 2,3 & 2,2 & 2,2 & 2,1 & 2,1 & 2,1 & 2,1 & 2,0 & 2,0 & 2,0 & 1,8 \\
\hline Rwzi & - & - & - & - & - & - & - & - & - & - & - & - & - & - & - & - \\
\hline Industriële lozingen & 0,00 & 0,00 & 0,00 & 0,00 & 0,00 & 0,00 & 0,00 & 0,00 & 0,00 & 0,00 & 0,00 & 0,00 & 0,00 & 0,00 & 0,00 & 0,00 \\
\hline Overige emissies & 0,02 & 0,42 & 0,10 & 0,02 & 0,01 & 0,01 & 0,01 & 0,00 & 0,00 & 0,00 & 0,00 & 0,00 & 0,00 & 0,00 & 0,00 & 0,04 \\
\hline Inlaat & 1,8 & 2,8 & 3,4 & 5,8 & 3,2 & 2,8 & 4,5 & 2,1 & 2,8 & 4,3 & 2,8 & 4,5 & 3,1 & 3,5 & 3,2 & 3,4 \\
\hline Directe kwel/wegzijging & $-1,7$ & $-2,1$ & $-1,8$ & $-1,6$ & $-1,7$ & $-1,7$ & $-1,7$ & $-1,6$ & $-1,6$ & $-1,4$ & $-1,3$ & $-1,2$ & $-1,2$ & $-1,1$ & $-1,2$ & $-1,5$ \\
\hline Uit- en afspoeling stedelijk & 0,06 & 0,07 & 0,07 & 0,03 & 0,04 & 0,04 & 0,05 & 0,07 & 0,04 & 0,04 & 0,05 & 0,07 & 0,04 & 0,06 & 0,04 & 0,05 \\
\hline Eenheden/honden/bladval & 0,15 & 0,15 & 0,15 & 0,15 & 0,15 & 0,15 & 0,15 & 0,15 & 0,15 & 0,15 & 0,15 & 0,15 & 0,15 & 0,15 & 0,15 & 0,15 \\
\hline Totaal IN & 14,6 & 14,7 & 12,1 & 8,7 & 9,1 & 9,0 & 13,4 & 14,0 & 9,9 & 9,3 & 10,7 & 12,3 & 9,2 & 10,2 & 8,5 & 11,0 \\
\hline Retentie & 8,1 & 8,4 & 6,9 & 5,1 & 5,4 & 5,4 & 7,5 & 7,8 & 5,8 & 5,3 & 6,0 & 6,7 & 5,2 & 5,7 & 4,6 & 6,3 \\
\hline Totaal UIT (berekend) & 6,4 & 6,3 & 5,1 & 3,5 & 3,7 & 3,7 & 5,8 & 6,2 & 4,2 & 4,0 & 4,7 & 5,5 & 4,0 & 4,5 & 3,7 & 4,8 \\
\hline Totaal UIT ('gemeten') & 4,2 & 4,1 & 4,3 & 1,9 & 2,7 & 2,2 & 2,6 & 4,4 & 2,4 & 2,4 & 2,6 & 3,0 & 3,2 & 3,5 & 2,2 & 3,0 \\
\hline Fosfor & 2000 & 2001 & 2002 & 2003 & 2004 & 2005 & 2006 & 2007 & 2008 & 2009 & 2010 & 2011 & 2012 & 2013 & 2014 & Gemiddeld \\
\hline Uit- en afspoeling landbouw & $-0,11$ & $0-0,24$ & $-0,01$ & $-0,68$ & $-0,33$ & $-0,29$ & $-0,05$ & 0,34 & $-0,11$ & $-0,47$ & $-0,03$ & 0,13 & $-0,11$ & $-0,12$ & $-0,24$ & $-0,12$ \\
\hline Uit- en afspoeling natuur & 0,65 & 0,79 & 0,66 & 0,12 & 0,37 & 0,37 & 0,55 & 0,81 & 0,49 & 0,24 & 0,54 & 0,64 & 0,45 & 0,45 & 0,37 & 0,50 \\
\hline Overige landbouwemissies & 0,11 & 0,04 & 0,04 & 0,04 & 0,04 & 0,08 & 0,03 & 0,03 & 0,00 & 0,00 & 0,06 & 0,07 & 0,05 & 0,05 & 0,05 & 0,05 \\
\hline Atmosferische depositie & - & - & - & - & - & - & - & - & - & - & - & - & - & - & - & - \\
\hline Rwzi & - & - & - & - & - & - & - & - & - & - & - & - & - & - & - & - \\
\hline Industriële lozingen & 0,00 & 0,00 & 0,00 & 0,00 & 0,00 & 0,00 & 0,00 & 0,00 & 0,00 & 0,00 & 0,00 & 0,00 & 0,00 & 0,00 & 0,00 & 0,00 \\
\hline Overige emissies & 0,00 & 0,00 & 0,02 & 0,00 & 0,00 & 0,00 & 0,00 & 0,00 & 0,00 & 0,00 & 0,00 & 0,00 & 0,00 & 0,00 & 0,00 & 0,00 \\
\hline Inlaat & 0,41 & 0,64 & 0,69 & 1,1 & 0,72 & 0,61 & 0,89 & 0,42 & 0,66 & 0,92 & 0,64 & 0,91 & 0,62 & 0,74 & 0,70 & 0,71 \\
\hline Directe kwel/wegzijging & $-0,56$ & $-0,63$ & $-0,57$ & $-0,36$ & $-0,41$ & $-0,51$ & $-0,45$ & $-0,43$ & $-0,45$ & $-0,34$ & $-0,28$ & $-0,25$ & $-0,29$ & $-0,24$ & $-0,32$ & $-0,41$ \\
\hline Uit- en afspoeling stedelijk & 0,01 & 0,01 & 0,01 & 0,00 & 0,00 & 0,00 & 0,01 & 0,01 & 0,00 & 0,00 & 0,00 & 0,01 & 0,00 & 0,01 & 0,00 & 0,01 \\
\hline Eenheden/honden/bladval & 0,03 & 0,03 & 0,03 & 0,03 & 0,03 & 0,03 & 0,03 & 0,03 & 0,03 & 0,03 & 0,03 & 0,03 & 0,03 & 0,03 & 0,03 & 0,03 \\
\hline Totaal IN & 0,54 & 1,1 & 0,86 & 0,28 & 0,42 & 0,30 & 1,0 & 1,2 & 0,63 & 0,39 & 0,97 & 1,5 & 0,77 & 0,93 & 0,61 & 0,77 \\
\hline Retentie & 0,39 & 0,67 & 0,49 & $-0,03$ & 0,19 & 0,20 & 0,45 & 0,68 & 0,34 & 0,09 & 0,41 & 0,60 & 0,32 & 0,35 & 0,24 & 0,36 \\
\hline Totaal UIT (berekend) & 0,15 & 0,44 & 0,37 & 0,31 & 0,23 & 0,10 & 0,55 & 0,52 & 0,29 & 0,31 & 0,56 & 0,94 & 0,44 & 0,59 & 0,37 & 0,41 \\
\hline Totaal UIT ('gemeten') & 0,96 & 1,0 & 0,86 & 0,26 & 0,44 & 0,60 & 0,57 & 1,2 & 0,51 & 0,38 & 0,48 & 0,58 & 0,58 & 0,65 & 0,42 & 0,63 \\
\hline
\end{tabular}


Tabel B5.4

Stikstof-en fosforbalans voor de periode 2000-2014 voor deelgebied Verdoold

\begin{tabular}{|c|c|c|c|c|c|c|c|c|c|c|c|c|c|c|c|c|}
\hline Stikstof & 2000 & 2001 & 2002 & 2003 & 2004 & 2005 & 2006 & 2007 & 2008 & 2009 & 2010 & 2011 & 2012 & 2013 & 2014 & gemiddeld \\
\hline Uit- en afspoeling landbouw & 160 & 172 & 138 & 68.5 & 110 & 106 & 122 & 160 & 121 & 74.2 & 108 & 110 & 94.3 & 94.3 & 83.5 & 115 \\
\hline Uit- en afspoeling natuur & 25.1 & 25.3 & 20.6 & 11.4 & 14.0 & 13.1 & 20.8 & 21.7 & 15.5 & 13.3 & 16.5 & 16.3 & 14.3 & 16.7 & 12.0 & 17.1 \\
\hline Overige landbouwemissies & 8.0 & 6.4 & 6.4 & 6.2 & 6.5 & 6.2 & 3.9 & 4.8 & 1.8 & 1.8 & 5.1 & 5.3 & 4.7 & 4.7 & 4.7 & 5.1 \\
\hline Atmosferische depositie & 25.4 & 32.8 & 10.3 & 10.3 & 31.3 & 23.8 & 23.3 & 23.0 & 21.9 & 21.7 & 22.1 & 21.8 & 21.4 & 21.4 & 21.4 & 22.2 \\
\hline Rwzi & 2.2 & 2.9 & 3.2 & 1.9 & 2.9 & 2.4 & 2.6 & 2.7 & 2.5 & 3.2 & 3.6 & 2.7 & 5.5 & 3.1 & 3.1 & 3.0 \\
\hline Industriële lozingen & 0.06 & 0.07 & -0.01 & 0.05 & 0.14 & 0.05 & 0.10 & 0.11 & 0.00 & 0.00 & 0.00 & 0.00 & 0.00 & 0.00 & 0.00 & 0.04 \\
\hline Overige emissies & 2.7 & 2.9 & 5.0 & 2.3 & 1.5 & 1.1 & 0.64 & 0.43 & 0.31 & 0.22 & 0.28 & 0.28 & 0.32 & 0.32 & 0.32 & 1.3 \\
\hline Inlaat & 18.5 & 26.1 & 33.3 & 52.9 & 28.6 & 23.2 & 36.1 & 19.3 & 27.9 & 28.3 & 23.5 & 29.7 & 24.6 & 34.2 & 31.4 & 29.8 \\
\hline Directe kwel/wegzijging & -10.0 & -9.7 & -9.9 & -8.8 & -9.2 & -8.5 & -8.0 & -8.1 & -7.4 & -6.6 & -7.0 & -6.1 & -5.4 & -5.3 & -5.1 & -7.7 \\
\hline Uit- en afspoeling stedelijk & 0.88 & 1.0 & 0.97 & 0.48 & 0.65 & 0.68 & 0.81 & 0.94 & 0.68 & 0.54 & 0.73 & 0.88 & 0.66 & 0.80 & 0.66 & 0.76 \\
\hline Eenheden/honden/bladval & 1.3 & 1.3 & 1.3 & 1.3 & 1.3 & 1.3 & 1.3 & 1.3 & 1.3 & 1.3 & 1.3 & 1.3 & 1.3 & 1.3 & 1.3 & 1.3 \\
\hline Totaal IN & 234 & 261 & 209 & 147 & 188 & 169 & 204 & 226 & 185 & 148 & 174 & 182 & 162 & 172 & 153 & 188 \\
\hline Retentie & 122 & 135 & 110 & 77.7 & 98.5 & 89.0 & 106 & 117 & 96.2 & 77.4 & 90.7 & 93.9 & 83.5 & 88.4 & 79.2 & 97.7 \\
\hline Totaal UIT (berekend) & 112 & 126 & 99.7 & 68.9 & 89.3 & 80.5 & 97.8 & 109 & 88.8 & 70.7 & 83.7 & 87.8 & 78.1 & 83.1 & 74.0 & 90.0 \\
\hline Totaal UIT ('gemeten') & 102 & 103 & 113 & 56.6 & 88.1 & 57.8 & 72.1 & 117 & 69.5 & 63.4 & 78.3 & 81.6 & 69.6 & 68.7 & 60.6 & 80.2 \\
\hline Fosfor & 2000 & 2001 & 2002 & 2003 & 2004 & 2005 & 2006 & 2007 & 2008 & 2009 & 2010 & 2011 & 2012 & 2013 & 2014 & Gemiddeld \\
\hline Uit- en afspoeling landbouw & 19.0 & 23.2 & 19.9 & 8.1 & 13.5 & 13.9 & 16.8 & 21.9 & 15.4 & 10.6 & 15.5 & 18.7 & 14.7 & 14.1 & 12.3 & 15.8 \\
\hline Uit- en afspoeling natuur & 2.4 & 2.8 & 2.4 & 0.67 & 1.4 & 1.4 & 2.0 & 2.8 & 1.7 & 1.0 & 1.9 & 2.4 & 1.6 & 1.8 & 1.4 & 1.8 \\
\hline Overige landbouwemissies & 1.8 & 0.49 & 0.53 & 0.47 & 0.51 & 1.4 & 0.29 & 0.29 & 0.06 & 0.06 & 1.2 & 1.2 & 1.0 & 1.0 & 1.0 & 0.73 \\
\hline Atmosferische depositie & - & - & - & - & - & - & - & - & - & - & - & - & - & - & - & - \\
\hline Rwzi & 0.38 & 0.70 & 0.95 & 0.88 & 0.84 & 0.84 & 1.2 & 1.2 & 1.2 & 1.4 & 0.95 & 1.2 & 1.9 & 0.84 & 0.84 & 1.0 \\
\hline Industriële lozingen & 0.02 & 0.02 & 0.02 & 0.01 & 0.02 & 0.02 & 0.01 & 0.01 & 0.00 & 0.00 & 0.00 & 0.00 & 0.000 & 0.00 & 0.00 & 0.01 \\
\hline Overige emissies & 0.44 & 0.35 & 0.80 & 0.34 & 0.20 & 0.19 & 0.10 & 0.06 & 0.04 & 0.03 & 0.04 & 0.04 & 0.05 & 0.05 & 0.05 & 0.19 \\
\hline Inlaat & 4.5 & 6.2 & 7.4 & 11.7 & 7.3 & 5.5 & 8.4 & 3.9 & 6.6 & 9.1 & 9.4 & 6.4 & 5.9 & 8.4 & 7.8 & 7.0 \\
\hline Directe kwel/wegzijging & -0.99 & -1.2 & -1.1 & -0.66 & -0.78 & -1.1 & -1.2 & -1.2 & -1.1 & -0.74 & -0.89 & -0.60 & -1.1 & -1.1 & -0.90 & -0.98 \\
\hline Uit- en afspoeling stedelijk & 0.09 & 0.10 & 0.10 & 0.05 & 0.07 & 0.07 & 0.08 & 0.09 & 0.07 & 0.05 & 0.07 & 0.09 & 0.07 & 0.08 & 0.07 & 0.08 \\
\hline Eenheden/honden/bladval & 0.28 & 0.28 & 0.28 & 0.28 & 0.28 & 0.28 & 0.28 & 0.28 & 0.28 & 0.28 & 0.28 & 0.28 & 0.28 & 0.28 & 0.28 & 0.28 \\
\hline Totaal IN & 27.8 & 32.9 & 31.3 & 21.8 & 23.3 & 22.4 & 28.0 & 29.3 & 24.3 & 21.8 & 25.4 & 29.6 & 24.5 & 25.4 & 22.8 & 26.0 \\
\hline Retentie & 12.3 & 14.7 & 13.3 & 7.2 & 9.4 & 9.4 & 11.6 & 13.6 & 10.3 & 8.1 & 10.6 & 12.5 & 10.1 & 10.2 & 9.0 & 10.8 \\
\hline Totaal UIT (berekend) & 15.5 & 18.2 & 18.0 & 14.6 & 13.9 & 13.0 & 16.4 & 15.74 & 14.0 & 13.7 & 14.8 & 17.1 & 14.3 & 15.3 & 13.9 & 15.2 \\
\hline Totaal UIT ('gemeten') & 12.9 & 14.2 & 13.0 & 5.6 & 7.5 & 8.5 & 11.7 & 20.3 & 10.1 & 8.8 & 11.6 & 9.5 & 11.4 & 11.7 & 8.3 & 11.0 \\
\hline
\end{tabular}


Wageningen Environmental Research Postbus 47

6700 AA Wageningen

T 0317480700

www.wur.nl/environmental-research

Wageningen Environmental Research

Rapport 2738

ISSN 1566-7197
De missie van Wageningen University \& Research is 'To explore the potential of nature to improve the quality of life'. Binnen Wageningen University \& Research bundelen Wageningen University en gespecialiseerde onderzoeksinstituten van Stichting Wageningen Research hun krachten om bij te dragen aan de oplossing van belangrijke vragen in het domein van gezonde voeding en leefomgeving. Met ongeveer 30 vestigingen, 5.000 medewerkers en 10.000 studenten behoort Wageningen University \& Research wereldwijd tot de aansprekende kennisinstellingen binnen haar domein. De integrale benadering van de vraagstukken en de samenwerking tussen verschillende disciplines vormen het hart van de unieke Wageningen aanpak.

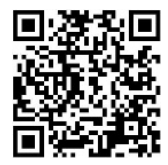





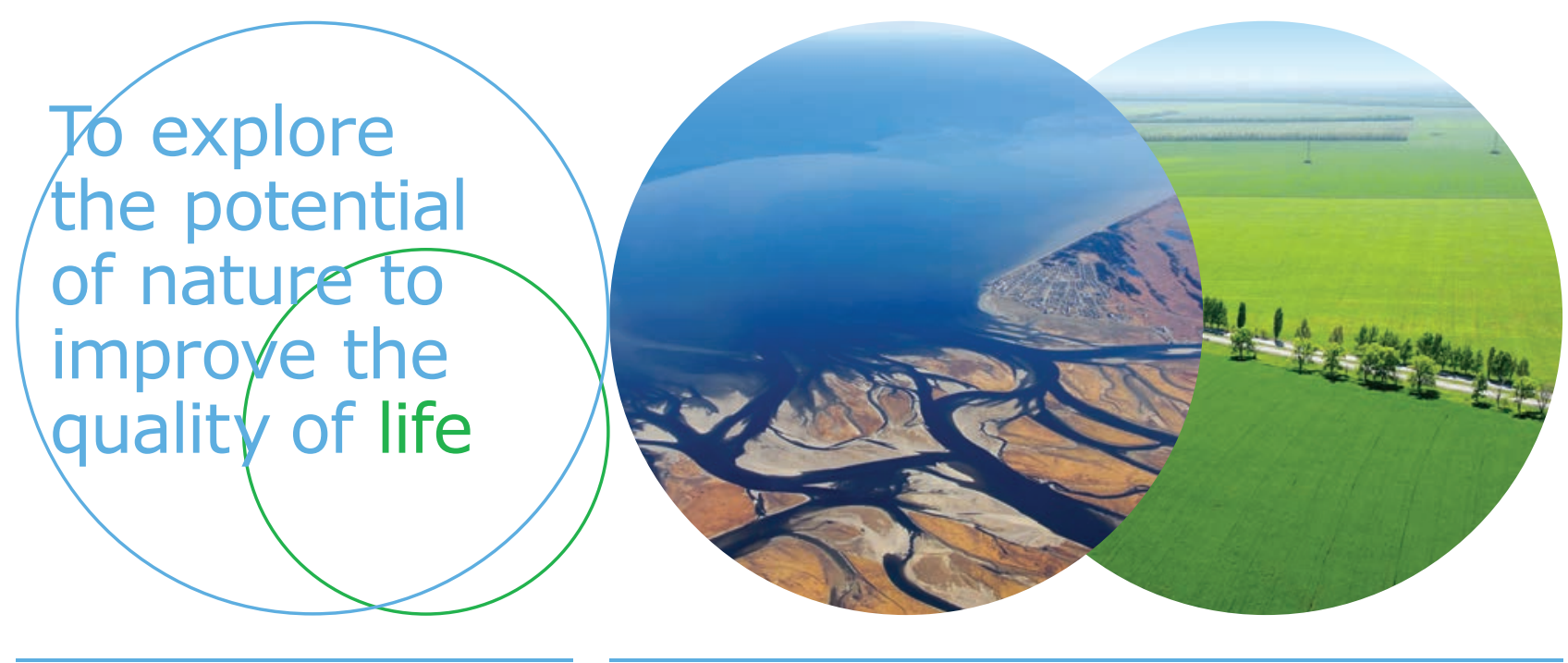

Wageningen Environmental Research Postbus 47

$6700 \mathrm{AB}$ Wageningen

T 317480700

www.wur.nl/environmental-research

Rapport 2738

ISSN 1566-7197
De missie van Wageningen University \& Research is 'To explore the potential of nature to improve the quality of life'. Binnen Wageningen University \& Research bundelen Wageningen University en gespecialiseerde onderzoeksinstituten van Stichting Wageningen Research hun krachten om bij te dragen aan de oplossing van belangrijke vragen in het domein van gezonde voeding en leefomgeving. Met ongeveer 30 vestigingen, 5.000 medewerkers en 10.000 studenten behoort Wageningen University \& Research wereldwijd tot de aansprekende kennisinstellingen binnen haar domein. De integrale benadering van de vraagstukken en de samenwerking tussen verschillende disciplines vormen het hart van de unieke Wageningen aanpak. 